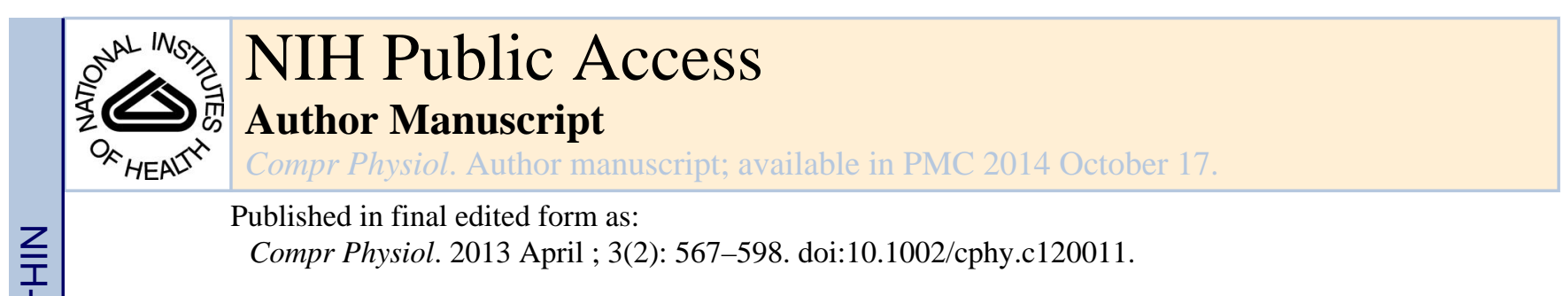

\title{
Liver Immunology
}

Dimitrios P. Bogdanos ${ }^{a}$, Bin Gaob, and M. Eric Gershwinc, ${ }^{c}$

anstitute of Liver Studies, Transplantation Immunology and Mucosal Biology, King's College

London School of Medicine at King's College Hospital, London, UK

bLaboratory of Liver Diseases, National Institute on Alcohol Abuse and Alcoholism, National Institutes of Health, Bethesda, MD, USA

'Division of Rheumatology, Allergy and Clinical Immunology, University of California at Davis School of Medicine, Davis, CA, USA

\section{Abstract}

The liver is the largest organ in the body and is generally regarded by non-immunologists as not having lymphoid function. However, such is far from accurate. This review highlights the importance of the liver as a lymphoid organ. Firstly, we discuss experimental data surrounding the role of liver as a lymphoid organ. The liver facilitates a tolerance rather than immunoreactivity, which protects the host from antigenic overload of dietary components and drugs derived from the gut and is also instrumental to fetal immune tolerance. Loss of liver tolerance leads to autoaggressive phenomena which if are not controlled by regulatory lymphoid populations may lead to the induction of autoimmune liver diseases. Liver-related lymphoid subpopulations also act as critical antigen-presenting cells. The study of the immunological properties of liver and delineation of the microenvironment of the intrahepatic milieu in normal and diseased livers provides a platform to understand the hierarchy of a series of detrimental events which lead to immune-mediated destruction of the liver and the rejection of liver allografts. The majority of emphasis within this review will be on the normal mononuclear cell composition of the liver. However, within this context, we will discus select, but not all, immune mediated liver disease and attempt to place these data in the context of human autoimmunity.

\section{Keywords}

autoimmune disease; biliary epithelial cell; hepatocytes; immunity; liver; lymphocytes; tolerance

\section{Introduction}

The liver is the largest solid organ of the human body, accounting for almost $2 \%$ of adult body weight and weighing approximately $1.5 \mathrm{~kg}$; it performs an amazing number of tasks that support the function of other organs and impacts all physiologic systems. An essential function of the liver is protein synthesis and metabolism, including the metabolism of amino

*Corresponding Author: Division of Rheumatology, Allergy and Clinical Immunology, University of California at Davis School of Medicine, 451 Health Sciences Drive, Suite 6510, Tel: +1-530-752-2884, Fax: +1-530-752-4669, megershwin@ucdavis.edu.

Conflict of Interest: None of the authors has a conflict of interest to declare. 
acids, carbohydrates, lipids and vitamins. However, the liver is also responsible for the removal of pathogens and exogenous antigens from the systemic circulation. The key position of the liver (Figure 1) and its unique vasculature allow it to carry out the degradation of toxins and waste products.

The role of the liver as the main metabolic organ increases the rate of exposure to newly produced neo-antigens and enhances the inherited risk of overactivation of components of the immune system with potentially harmful consequences for cell homeostasis. Thus, the immune system developed dedicated mechanisms to be able to "switch" from a tolerant to a responsive state at any given time ${ }^{1}$. Early in the history of experimental transplantation, transplant surgeons were intrigued to note that while kidney, skin, pancreas and other allografts were rapidly rejected, allogeneic liver grafts were more tolerant. This prompted investigators to consider that the liver is predominantly an organ biased towards tolerance rather than a reactive state which would otherwise lead to rejections. The scientific basis for this tolerant state remained elusive for many years.

\section{Historical Perspectives}

The first human liver transplant was performed in 1963 by Starzl, ${ }^{2}$ with significant shortterm success in 1967 when a recipient survived for more than a year. Subsequently, the systematic administration of cyclosporin by Calne and colleagues dramatically improved the outcome of the patients receiving a liver allograft ${ }^{3,4}$. Further, it was noted in 1969 that liver allografts between unrelated pigs were not rejected in spite of MHC mismatch; the transplanted livers did not require high doses of immunosuppression to be sustained ${ }^{5}$. A seminal study, conducted two years before Calne's report, from Cantor and Dumont demonstrated that administration of antigens to animals via the portal vein was tolerated better compared to systemic administration ${ }^{6}$. Subsequent studies confirmed the potential acceptance of MHC mismatched liver grafts in other species. Further, liver transplantation confers tolerance to heart and skin grafts from the same donors, while heart and skin grafts from other donors were immediately rejected. Interestingly, the rejection of other transplanted organs can be modulated by subsequent transplantation. Similarly, cotransplantation of human liver with another organ limits the likelihood of immediate rejection of the second organ and improves the survival of the allograft. The natural regenerative capacity of the liver parenchymal cells is significant; $25 \%$ of residual liver is sufficient for regeneration within a few weeks in rodents and a few months in humans. Because of its anatomical location, the liver is continuously exposed to an overload of antigenic stimuli which includes exogenous pathogens, dietary components and xenobiotics, including drugs and toxins.

\section{Microanatomy of the Liver as an Immunological Organ}

To achieve its multifaceted tasks, the liver is composed of a myriad of cell types, largely sub-divided in parenchymal and non-parenchymal cells (Table 1) ${ }^{7}$. Most of the liver volume is occupied by parenchymal cells (hepatocytes); these cells occupy approximately $78-80 \%$ of the total liver tissue, compared to just 5-6\% of non-parenchymal cells ${ }^{7-11}$ (Table 1). The remaining $14-17 \%$ of the total liver tissue corresponds to cellular components of the 
extracellular space (Figure 2) ${ }^{7}$. The non-parenchymal cells consist of a diverse set of cells, including 45\% liver sinusoidal endothelial cells (LSECs), 33\% Kupffer cells (KCs), and $22 \%$ hepatic stellate cells (HSCs) ${ }^{12}$ (Table 1 and Figure 3 ). The liver can be considered to have two separate anatomic areas, the parenchyma and the portal tracts. Structurally, the liver can be further subdivided into five systems comprising the vascular system, the hepatic lobule, the hepatic sinusoidal system, the biliary system and the stroma. Each of these systems - directly or indirectly - plays an important role in the homeostasis of the innate and adaptive immune system.

\section{Hepatic lobule}

The simplest way to describe the cellular anatomy of the liver is by light microscopy. Thus, the hepatic lobule is not only the structural but also the functional unit of the liver ${ }^{13}$. These lobules are centered on central veins like spokes in wheel, and their periphery is demarcated by arbitrary lines joining each of the surrounding regions of portal tracts (Figure 4). Each portal tract consists of an intrahepatic bile duct and a collection of blood vessels including a branch of both the hepatic artery and portal vein. Such lining formulates a roughly hexagonal assembly of hepatocyte plates ${ }^{13}$, the extension of which forms the basis of the one-cell thick liver cell layers consisting of $15-25$ cells each.

\section{The hepatic vasculature}

The liver has a dual blood supply as it receives arterial blood from the right and left hepatic arteries and venous blood from the hepatic portal vein. The antigen-rich blood delivered through the portal vein accounts for more than $75-80 \%$ of the total blood. This blood originates from the stomach, alimentary tract, rectum and spleen, and contains large concentrations of antigens from dietary components and bacterial products from gut bacteria such as lipopolysaccharide endotoxin (LPS). This can be found at a concentration of up to 1 $\mathrm{ng} / \mathrm{ml}^{14}$. Also, metastatic cells pass through the liver, which also has to deal with the load of detoxified byproducts with oncogenic potential. The remaining $20-25 \%$ is oxygenated blood delivered through the hepatic arteries which are branches of the celiac axis. The blood leaving the liver is drained into the inferior vena cava via the hepatic veins. The liver receives $1.5 \mathrm{~L}$ ( $30 \%$ of the total blood volume) each minute. Thus, the total volume of blood in the human body circulates through the liver approximately 360 times each day. The blood flows through the vascular sinusoids, and is drained into central veins or terminal hepatic venules, which are the branches of the hepatic veins.

\section{Hepatic sinusoidal system}

The hepatocytes form one cell thick plates and are separated from the bloodstream by a nonparenchymal, thin fenestrated (porous) barrier forming a labyrinth of specialized capillaries, termed liver sinusoids (Figure 5). These capillaries are primarily formed by liver sinusoidal endothelial cells (LSECs) ${ }^{15}$. The liver sinusoids are designed to allow easy transmission of molecules and cellular mediators between the sinusoids and the hepatocytes. To achieve such transfer, LSECs lack a basement membrane, making them permeable. Under normal conditions, the space of Disse formed between hepatocytes, LSECs and HSCs, allows exchange of cellular mediators without the need of a direct contact. A direct contact between 
hepatocytes and sinusoidal cells can be achieved from clusters of endothelial cells which contain small holes (or fenestrations) ${ }^{16}$ which perforate the cytoplasm and form 'sieve plates' ${ }^{17-19}$ (Figure 5). Fenestrae manage the exchange of solutes and particles between the sinusoidal blood and the space of Disse ${ }^{18,19}$. Blood also passes over a population of macrophages called Kupffer cells (KC). KCs account for approximately $80 \%$ of all macrophages in the body ${ }^{20}$. Their strategic position enables them to clear the blood from endotoxins and antigens and to eliminate microorganisms by phagocytosis. HSCs (also known as Ito cells) are located in close proximity to the vascular sinusoids and in particular in the vicinity of the terminal hepatic venules. Because of the small diameter of sinusoids, even minimal increases in systemic venous pressure can create stasis. Such stasis encourages lymphocyte extravasation and extends direct contact of APCs and lymphocyte populations.

\section{The liver as a lymphoid organ}

Organs such as the thymus, lymph nodes, and spleen are "classical" lymphoid organs. However, other organs such as the gut and liver consist of cells whose primary function may not be immunological but nonetheless still perform essential immune tasks. Within these respective organs there are resident cells of the innate and adaptive immune system. Within a normal liver, the lymphocyte population is largely resident in the portal tract but can be also scattered throughout the parenchyma. The composition and localization of these lymphocyte populations changes dramatically when the liver architecture is altered as a consequence of acute or chronic inflammatory conditions. It is therefore not surprising, that hepatocytes and BECs are sites of immune-mediated destruction induced by a variety of infectious xenobiotic and tumor-originated sources ${ }^{1}$. The anatomic position of the liver and its distinctive vasculature accounts for its unique ability to continuously exchange immunological information. The antigen-rich blood passing through the liver sinusoids is "scanned" achieved by a complex network of conventional and non-conventional antigen presenting cells (APCs) ${ }^{21,22}$.

\section{Composition of the Liver Immune System}

The human liver has a lymphocyte population normally resident in the portal tract, but also scattered throughout the parenchyma ${ }^{23-26}$. Approximately 500,000 to one million lymphocytes can be retrieved from $100 \mathrm{mg}$ of normal human liver tissue, bringing the total number of these cells to approximately $0.75-1.510^{10}$ cells for a liver weighing $1.5 \mathrm{~kg}^{23}$. The lymphoid repertoire includes significant numbers of T-cells, B cells, natural killer (NK) and natural killer T (NKT) cells (Figure 6). The relative contribution ${ }^{1,27}$ of these cells in the liver is illustrated in Figure 7. Using CD3 as a pan-T cell marker, these lymphoid populations can be subdivided into $\mathrm{CD}^{+}$and $\mathrm{CD}^{-}$. $\mathrm{CD}^{+}{ }^{+}$lymphocytes outnumber $\mathrm{CD}^{-}$ lymphoid cells. The most widely used marker for NK cells is CD56; all three subpopulations $\mathrm{CD}^{+}{ }^{+} \mathrm{CD} 56^{-} \mathrm{T}$ cells, $\mathrm{CD} 3-\mathrm{CD} 56^{+} \mathrm{NK}$ cells and $\mathrm{CD}^{+}{ }^{+} \mathrm{CD} 56^{+} \mathrm{NKT}$ cells have cytotoxic activity. B lymphocytes comprise only $5 \%$ of the total lymphocytes ${ }^{23-26}$. Many of the liver-resident lymphocytes differ phenotypically and functionally from circulating lymphocytes $24,25,28-31$, for reasons poorly understood ${ }^{27}$. The hepatic lymphocyte repertoire includes conventional and unconventional lymphocyte sub-populations of both the innate and the adaptive immune system. 


\section{$a \beta-$ and $\gamma \delta-T$ cells in liver immunity}

The conventional T-cell population consists of $\mathrm{CD} 8^{+}$and $\mathrm{CD} 4^{+} \mathrm{T}$ cells exhibiting a diverse repertoire with a $\beta$-chain $\mathrm{T}$ cell receptors (TCR). These receptors recognize short peptidyl sequences from antigens in the context of MHC class I and class II molecules for CD8 and $\mathrm{CD} 4$, respectively. More than $80 \%$ of the $\mathrm{CD}^{+} \mathrm{T}$ cells are $\alpha \beta \mathrm{T}$-cells, with the remainder expressing the $\gamma \delta \mathrm{T}$-cell receptor in the liver ${ }^{1}$. The mean prevalence rate of $15 \%$ for $\gamma \delta \mathrm{TCR}+$ cells is 5 times higher in the liver compared to the periphery (range 1-5\%) ${ }^{32,33}$. Lymphocyte repertoires rich in $\gamma \delta \mathrm{TCR}+$ cells are also found in skin, the gut and the genitourinary tract. The role of $\gamma \delta \mathrm{TCR}+$ cells in the immune homeostasis of the liver remains elusive. Although a protective role of these cells in the concavalin A-induced animal model of acute liver failure has been reported ${ }^{34}$, the protective role is initiated by $\mathrm{V} \gamma 4$ and not $\mathrm{V} \gamma 1, \gamma \delta \mathrm{T}$ cells. IL-17A deficient $\gamma \delta \mathrm{T}$ cells are unable to protect from liver destruction, suggesting that IL-17A is an important mediator of such protection. $\mathrm{V} \gamma 4$ and not $\mathrm{V} \gamma 1, \gamma \delta \mathrm{T} \mathrm{T}$ cells are the major subsets of peripheral lymphoid $\gamma \delta \mathrm{T} T \mathrm{~T}$ cells. A different set of experiments have shown that the $\gamma \delta$ T cells protect from liver failure by targeting NKT cells $^{34}$. An earlier report has suggested that IL-17A induced by $\gamma \delta \mathrm{T}$ cells is expressed in the liver of mice infected with Listeria monocytogenes at an early stage of infection and plays an important role in the initiation of innate immune responses ${ }^{35}$.

The role of $\gamma \delta$ T cells is not limited to control of infection but appears to also play distinct immunoregulatory roles in tumor immunity ${ }^{36,37}$. They have also been involved in the induction and maintenance of liver-specific autoimmunity, as they appear increased in patients with active autoimmune hepatitis and primary sclerosing cholangitis ${ }^{38-41}$. Some Tcells do not express CD4 or CD8 and are known as 'double negative' T cells. They have been studied mainly in mice, and appear to develop extrathymically and expresses specific V TCR $\beta$ genes ${ }^{42,43}$. They can be found in liver, expressing either the $\alpha \beta$ or $\gamma \delta$ TCR and are considered to be cells with primarily regulatory properties ${ }^{23,44-46}$, they may be critical to induction of autoimmunity ${ }^{47}$.

The participation of conventional T-cells bearing a $\beta$ TCRs in the immune homeostasis of a normal liver is by far the best studied and is reviewed elsewhere ${ }^{1,48,49}$; the role played by these cells in the induction of immune-mediated liver injury has been extensively studied $^{1,48,49}$.

\section{NK and NKT cells in the liver}

NK cells are bone-marrow derived large granular cells; their main task is to kill target cells. NK cells represent approximately $20-30 \%$ of the total number of liver-resident lymphocytes, a percentage unusually high compared to less than 5\% seen in peripheral blood $^{25}$. Their over-representation in human liver probably relates to their primary role, which is surveillance for infection, killing of infected hepatocytes (Figure 8) and possibly malignant transformation. They are conventional constituents of the innate immune system, but emerging evidence, both in mice and humans, indicates that NK cells are 'educated' throughout the development in a way similar to that seen in lymphoid cells of the adaptive immune system ${ }^{50}$. NK cells acquire antigen-specific receptors, go through clonal expansion during exposure to infectious agents and produce long-lived memory cells. 
Liver lymphocytes are also enriched in NKT cells, accounting for 20-35\% of mouse liver lymphocytes and 10-15\% of rat and human liver lymphocytes (Gao et al., J Leukocyte Biology 2009, 86:513-528). NKT cells are a heterogeneous group of T lymphocytes that express both $\mathrm{NK}$ and $\mathrm{T}$ cell markers, and recognize the lipid antigens presented by the nonclassical MHC class I-like molecule CD1. The functions of NKT cells are mainly mediated via the production of a variety of cytokines (e.g. IFN- $\gamma$ and IL-4), which play important roles in regulating innate and adaptive immunity. Accumulating evidence suggests that NKT cells play a diverse role in liver injury, inflammation, fibrosis, and regeneration (Gao et al., J Leukocyte Biology 2009, 86:513-528; Park et al., Hepatology 2009, 49:1683-94).

The hypothesis that lymphocyte sub-populations participate in routine immuno-surveillant functions in normal liver has largely been based on evidence demonstrating that they express mature/activated phenotypes ${ }^{24,51}$. Early evidence suggested that these populations may have arisen locally, a finding that has implications not only in the maintenance of immune homeostasis but also in the induction of immune-mediated liver injury. Phenotypic and functional characterization of these liver-related lymphocytes has led to the appreciation of a role in the immunopathogenesis of liver diseases, including autoimmune liver diseases, chronic viral hepatitides, liver-related tumor immunology, alcoholic hepatitis, drug-induced immune-mediated liver disease and allograft rejection ${ }^{1,49}$.

\section{Liver-Related Antigen Presenting Cells in Immunity and Tolerance}

The liver is unique in its ability to recruit distinct cell types to become APCs; LSECs, KCs and hepatic DCs may all be considered conventional or classical liver APCs. However, under pathophysiological circumstances and during persistent liver inflammation, hepatocytes and BECs can express MHC II antigens and act as non-conventional APCs. Hepatocytes and BECs as APCs play an important role in the initiation and maintenance of processes important for loss of immunological tolerance. All these cells come in continuous contact with naïve $\mathrm{T}$ cells recirculating through the blood, and under normal of pathological conditions may participate in their activation (Figure 8$)^{52}$.

One working hypothesis to explain the ability of the liver to induce systemic tolerance ${ }^{21}$ is based on the assumption that liver-resident DCs have distinct properties which promote tolerance rather than an immune response. Another plausible explanation is the intrinsic tolerogenic capacity of liver-related APCs such as the LSECs or the KCs. Donor cell chimerism has also been postulated to account for the observed tolerance ${ }^{53}$. According to this scenario, donor-derived leukocytes including liver-resident APCs migrate to central lymphoid organs within 120 minutes post- transplantation, and persist for a long period, accounting for the hepatic tolerogenicity seen. Also, the systemic tolerance of the liver has been attributed to the induction of allospecific regulatory cells such as those with a CD4 ${ }^{+}$, $\mathrm{CD} 25^{+}, \mathrm{FoxP}^{+}$phenotype ${ }^{54}$. These mechanisms may act in isolation or in combination.

\section{Liver sinusoidal endothelial cells}

Wisse was the first to demonstrate that LSEC is a distinct cell type with a characteristic open fenestration without basement membrane or diaphragm ${ }^{16}$. Aging, liver disease and various 
stimuli co-cultured with LSECs (such as vascular endothelial growth factor) alter the number, size and localization of the fenestrations ${ }^{55-58}$. Wisse was also the first to suggest that because of the unusually high amounts of endocytic vehicles that LSECs contain, these cells are probably involved in the uptake of proteins circulating in sinusoidal blood ${ }^{16}$. This notion has been proven correct 15 years later when hyaluronic acid was identified as the first physiological macromolecule cleared from the blood by rat LSECs ${ }^{59}$.

The role of LSECs in hepatic tolerance and the generation of immunity has been investigated and several surface markers have been found to be expressed by resting and activated LSECs (Table 2). The LSEC is an efficient APC with multiple functions ${ }^{21,22}$. The capacity of LSECs to possess several of the properties seen in DCs, such as the expression of MHC class II, various co-stimulatory molecules, and CD11c and their ability to activate naive $\mathrm{T}$ cells has been reported ${ }^{60-68}$. LSECs can take up antigen using a multitude of receptors ${ }^{69}$. The question as to whether a) LSECs are efficient APCs and b) can induce Tcell tolerance has also been addressed systematically. Lohse et al ${ }^{60}$ were among the first to study the ability of LSECs to act as APC and demonstrated that LSECs are efficient APC, carrying functional B7-2 molecules ${ }^{60}$. The ability of LSECs to present soluble antigens to $\mathrm{CD}^{+} \mathrm{T}$ cells is down-regulated by IL- $10^{60}$. Subsequent work ${ }^{63}$ reflects that murine LSECs are efficient $\mathrm{APCs}^{63}$. However, levels of $\mathrm{MHC}$ class $\mathrm{II}^{63}$ are relatively low and stimulation of toll like receptors is unable to induce IL-12 expression ${ }^{63}$. Also, treatment with endotoxin down-regulates the surface expression of constitutively expressed MHC class II, and CD80/ CD86 co-stimulatory molecules ${ }^{63}$. These data suggest that although endotoxin does not alter the ability of LSEC to remove gut-derived peptides from circulation, it affects antigen processing and expression of accessory molecules ${ }^{63}$.

Contrary to these results, LSECs isolated from primed mice can present antigen and induce antigen-specific $\mathrm{CD} 8^{+} \mathrm{T}$ cell tolerance ${ }^{65}$. Also, adaptive transfer of LSECs isolated from ovalbumin-fed animals can induce antigen-specific T-cell tolerance to unfed animals, clearly indicating an involvement of LSECs in the induction of CD8 T cell tolerance against oral antigens ${ }^{66}$. The ability of murine LSECs to tolerize T cells across MHC barriers has been studied $^{70}$; LSECs can regulate a polyclonal population of $\mathrm{T}$ cells with direct allospecificity. Data have demonstrated the Fas/Fas ligand pathway as important in the tolerizing capacity of LSECs towards alloreactive T cells ${ }^{70}$. Though the molecular mechanisms responsible for LSEC-induced T cell anergy are poorly understood, reported data suggests that B7-H1 signaling on LSECs is a prerequisite for the induction of $\mathrm{CD} 8^{+} \mathrm{T}$ cell tolerance via programmed death (PD)-1 ligation ${ }^{71}$. Also, the contact of LSECs with DCs suppress neighboring antigen-presenting DCs to fully activate naive CD8 T cells ${ }^{72}$.

The capacity of LSECs as efficient APCs ex vivo and in vivo has been the focus of heated debate, as the results obtained have not been always supportive of their APC role ${ }^{21}$. Thus, in contrast to the findings presented above, Katz et al ${ }^{67}$ challenged the dogma that LSECs have DC properties expressing MHC class II antigens, CD40, CD80, and CD86 co-stimulatory molecules, and CD11c and are able to effectively stimulate naïve T-cells. Using isolated LSECs with the phenotypic markers of endothelial cells $\left(\mathrm{CD}^{-} 5^{-}, \mathrm{CD} 31^{+}, \mathrm{vWF}^{+}\right)($Table 2$)$, it was reported that such cells lacked the expression of CD11c, the most widely used marker of murine DC. Additionally, they had minimal expression of MHC class II and undetectable 
levels of CD40, CD80, and CD86. Such LSECs were able to capture antigen but could not induce IFN- $\gamma$ production or significant $\mathrm{CD}^{+}$or $\mathrm{CD} 8^{+} \mathrm{T}$-cell proliferation. The possibility that the tolerogenic effect of the liver may be due to the continuous exposure of LSECs to gut bacterial products has been tested experimentally. Physiological concentrations of entotoxin contained within the blood drained from the portal veins to the liver can induce the secretion of interleukin (IL)-10 from LSECs ${ }^{73}$; physiological concentrations of endotoxin appear to be able to down-regulate LSEC-mediated CD4 ${ }^{+}$T-cell activation via the modulatory effects they exert in the expression of MHC class II, CD80 and CD86 62 .

More recent studies have addressed the potential of diseased liver to provide a microenvironment which reverses the function of LSECs from tolerogenic to proinflammatory and highly immunogenic. LSECs from fibrotic livers induce T-cells to produce pro-inflammatory cytokines such as IFN- $\gamma$, IL-6, and TNF-a ${ }^{74}$. Such data clearly implicate LSECs in intrahepatic immune-mediated inflammation seen in hepatic fibrosis and possibly to liver allograft tolerance ${ }^{70,75,76}$.

\section{Kupffer cells}

The tolerogenic capacity of KCs has been demonstrated in the induction of tolerance to allergic and drug-induced reactions ${ }^{77,78}$. KCs have also been implicated in the induction of liver tolerance caused by preoperative donor-specific blood transfusion after liver transplantation ${ }^{79}$. Their important role in tolerance has been suggested because gadolinium chloride-induced blockade of KCs prevents the induction of tolerance by the portal venous route in rat cardiac allograft transplantation ${ }^{80,81}$. KCs can also produce prostaglandin E2, which in turn can inhibit antigen (ovalbumin)-specific T-cell activation by $\mathrm{DCs}^{82}$.

The close interplay of KCs with LSECs or Tregs may be of relevance to the tolerogenic capacity of the liver. Early studies on human KCs challenged with LPS have suggested that these cells can also release IL-10 ${ }^{73}$. In vitro experiments have also demonstrated that exogenous IL-10 down-regulates the secretion of IL- 6 and tumor necrosis factor (TNF)- $a$ by LPS-stimulated human $\mathrm{KCs}^{73}$. Kupffer cell-derived IL-10 may decrease the expression of both MHC class II and co-stimulatory molecules expressed by LSECs ${ }^{64}$. Kupffer cellproduced prostaglandin E2 abrogates the capacity of LSEC to activate cloned, antigenspecific CD4 ${ }^{+} \mathrm{T}$ cells ${ }^{64}$. Interaction of KCs with Tregs provoke the secretion of IL-10 by Tregs and facilitates the induction of systemic tolerance to hepatocyte-derived antigens, such as human a-1 antitrypsin ${ }^{83}$. Earlier data have demonstrated in a concavalin A-induced model of liver injury the ability of both Tregs and KCs to provoke liver tolerance to concanavalin A through the induction of IL- $10^{84}$. KCs can freely transcytose LSECs and can secrete cytokines and chemokines to eliminate pathogens.

\section{Hepatic dendritic cells}

Hepatic DCs appear in high numbers throughout the portal triad, surrounding the central vein ${ }^{85}$. A smaller number of DCs can also be found scattered throughout the parenchyma ${ }^{86}$. These DCs are largely sub-divided into five sub-sets on the basis of their phenotypic characteristics, including classical myeloid DCs (mDCs) and plasmacytoid DCs (pDCs). They also consist of a unique mixture of mDCs and pDCs, a group of lymphoid DCs and a 
group of NK DCs (or DC-like NKs). A simplified phenotypic subdivision based on specific surface markers for these sub-populations is as follows: lymphoid $\left(\mathrm{CD} 8 \mathrm{a}^{+}, \mathrm{B} 220^{-}\right.$, CD11b $\left.{ }^{-}\right)$; plasmacytoid $\left(\mathrm{CD} 8 \mathrm{a}^{-}, \mathrm{B} 220^{+}\right)$; myeloid $\left(\mathrm{CD} 8 \mathrm{a}^{-}, \mathrm{B} 220^{-}, \mathrm{CD} 11 \mathrm{~b}^{+}\right)$; myeloid \& plasmacytoid mixture (B220-, CD11b $)$; and NK DCs $\left(B 220^{-}, \mathrm{CD} 11 \mathrm{c}_{\text {int }}, \mathrm{CD}^{-} 9^{+}, 2 \mathrm{~B} 4^{++}\right.$, $\left.\mathrm{DX} 5^{+}\right)^{21,87,88}$. Several other markers have been used in the recent past to better identify and investigate these subsets of dendritic cells in mouse and human liver. Myeloid and lymphoid DCs are the main sub-populations ${ }^{22,89,90}$. Hepatic DCs are less immunogenic compared to their counterparts in spleen or other tissues ${ }^{89}$. The low immunogenicity of hepatic DCs has been attributed to differences in subtype composition between the liver and spleen, which reflects the lack of expression of constitutive costimulatory molecules ${ }^{89}$. However, hepatic DCs produce significantly higher amounts of cytokines and have a greater phagocytic capacity than the lymphoid organ counterparts ${ }^{91,92}$. The relative contribution of liver dendritic cell subsets in mouse liver ${ }^{91}$ is illustrated in Figure 5. Comparative analysis and morphometrics estimation of DCs in normal mice demonstrates that the normal liver contains more interstitial DCs compared to any other parenchymal organ ${ }^{93}$.

It has been suggested - but not yet been proven - that the large number of DCs within the liver may result from the large number of pathogen-associated molecular patterns (PAMPs) contained in portal blood ${ }^{22}$. PAMPs are responsible for the activation of pattern recognition patterns (PRPs) which activates hepatic scavenger cells and induces the production of IL-6 or other cytokines, subsequently inducing the over-expression of complement $\mathrm{C}$ and $\mathrm{C}$ reactive protein. This sequence of events is important for the induction of innate immunity, as acute phase proteins bind to pathogens and accelerate phagocytosis but abrogate the production of tumor necrosis factor (TNF)-a by Kupffer cells (KCs) $)^{94}$. The constitutive expression of PPRs initiates the expression of chemokines and adhesion molecules and promotes immune recruitment to liver. This recruitment drives a series of processes which control the fine balance between recruited effector and regulatory cells and their cytokine milieu, subsequently leading to either hepatic tolerance or immunity ${ }^{20}$. The cytokine milieu can cause hepatic DCs to become tolerogenic; these cytokines include - but are not limited to - IL-10, TGF- $\beta$ and are induced by the complex interplay of KCs, LSECs, HSCs and other cell composites $22,95-100$.

\section{Hepatic stellate cells}

HSCs have a dual role. Under normal conditions they control blood flow through the sinusoidal system, while in pathological conditions and upon exposure to various inflammatory stimuli appear to differentiate into myofibroblasts. They then secrete inhibitors of tissue matrix metalloproteinases, deposit collagen and generate fibrous tissue leading to liver fibrosis. Experimental data in support of the capacity of HSCs to act as APCs are limited ${ }^{101-103}$, in comparison to that of HSECs. Their tolerogenic capability has been indicated by studies demonstrating that transplanted HSCs effectively protect islet allografts from rejection in an islet transplantation mouse model ${ }^{104}$. HSC-exerted immunomodulation is regulated by the inducible expression of B7-H1, an inhibitory molecule of B7 family ${ }^{104}$; depletion of activated HSCs with gliotoxin decreases transplanted hepatocyte engraftment in rats ${ }^{105}$. 
HSCs present lipids to $\mathrm{CD} 4^{+}, \mathrm{CD} 8^{+} \mathrm{T}$-cells and NKT cells. Cultured HSCs can perform fluid-phase and receptor-mediated endocytosis and retain their ability for phagocytosis ${ }^{101}$. They express MHC class I and II molecules and lipid-presenting CD1b and CD1c molecules, as well as CD86, CD40 and other co-stimulatory molecules ${ }^{101,102}$. CD86 is also over-expressed when HSCs have been activated in vivo in a state of extended fibrosis and cirrhosis ${ }^{101}$. Exposure of HSCs to proinflammatory cytokines such as IFN $\gamma$ markedly upregulates CD80 ${ }^{101}$ while CD40 activation leads to a 10-fold increase of the secretion of IL-8 by HSCs and a 2 -fold increase of the monocyte chemoattractant protein-1 by the same cells ${ }^{102}$. Their potential tolerogenic capacity has been supported by their ability to produce vitamin A-derived retinoic acid and TGF $\beta$. Activated HSCs express the negative costimulator programmed death (PD)-L1 and can inhibit T-cell responses via B7-H1-mediated apoptosis $^{106 .}$

\section{Hepatocytes and biliary epithelial cells as APCs}

A wealth of experimental data reflect the ability of hepatocytes to serve as APCs. Murine studies have shown that the fenestrations of LSECs allow direct hepatocyte-T lymphocytes interaction ${ }^{107}$. Hepatocytes constitutively express intercellular adhesion molecule- 1 and addition of cytokines such as IFN- $\gamma$ leads to moderate expression of HLA class I molecules. This cytokine leads to significant enhancement of HLA class II only if used at high doses within cultures ${ }^{108}$. Hepatocytes prime naïve $\mathrm{CD} 8^{+} \mathrm{T}$ cell, even when they express low levels of MHC class I molecules ${ }^{109}$. These hepatocyte-primed naive T-cells can expand, but in the absence of co-stimulatory signals they undergo apoptosis, leading to intrahepatic tolerance by clonal deletion ${ }^{109-111}$. Also, when allogeneic hepatocytes are exposed to T-cells, T-cells activate and apoptose $\mathrm{e}^{112}$. In vivo experiments have also provided convincing evidence in support of the APC capacity of hepatocytes ${ }^{52,113,114}$.

The study of the immunogenicity of human BECs or human BEC lines has been studied ${ }^{115-120}$. BECs from normal human livers express HLA class I at a low frequency. HLA class II molecules are not expressed ${ }^{121}$. Infection with hepatotropic or hepatotrophic viruses enhances HLA class I expression ${ }^{115}$; cytomegalovirus infection leads to overexpression of HLA class leaves unaltered HLA class $\mathrm{II}^{115}$. Also, the same virus appears to reduce the rate of IFN- $\gamma$ induced de novo expression of HLA class II, leaving unaffected HLA class $\mathrm{I}^{115}$. Data have shown that cytokine-induced expression of adhesion molecules such as intercellular adhesion molecule-1 (ICAM-1), vascular cell adhesion molecule-1 (VCAM-1), and lymphocyte function-associated antigen-3 (LFA-3) of human BECs is comparable to that seen in Epstein-Barr virus-transformed B-cell lines, a known antigen presenting cell ${ }^{117}$. The expression of these adhesion molecules is a prerequisite for effector cells to exert their cytolytic action ${ }^{118}$. In hepatocytes, the expression of HLA class II is increased in cultures performed in the presence of IFN- $\gamma$ or when other pro-inflammatory cytokines are added ${ }^{117-120}$. The lack of costimulatory CD28 ligands renders cytokinestimulated human intraepithelial BECs unable to induce effective T-cell activation ${ }^{119}$. In pathological conditions such as that of PBC, destructed BECs overexpress HLA class II, as well as CD80 and CD86 co-stimulatory molecules ${ }^{116}$. While antigen presentation by CD80/ CD86-positive APCs induces T-cell activation, antigen presentation in the absence of sufficient CD80/CD86 costimulation may induce tolerance. However, the capacity of BECs 
to efficiently present antigens and to activate effector cells also depends on whether there is efficient control by regulatory cells.

Efficient antigen presentation and T-cell activation of cells not undergoing apoptosis is a complex process, the fate of which depends on the action exercised by regulatory T-cells in the microenvironment.

\section{Immune Mediated Liver Injury}

Viral or bacterial antigens that pass through the liver sinusoids generally induce an immune response; in most cases, an efficient immune response will remove the microorganism. However, this cannot always be achieved, and chronic infectivity may be the final outcome. Interestingly, neither hepatitis $\mathrm{B}$ nor hepatitis $\mathrm{C}$ are considered cytopathic. In fact, the destruction of the hepatocytes is the outcome of the host's immune response to clear the virus. This scenario implies that the liver becomes the victim of a friendly fire targeting the virus rather than the hepatocyte. Similarly, autoimmune liver diseases are models for investigation of mechanisms which lead to loss of immunological tolerance.

\section{Autoimmune liver diseases}

Autoimmune diseases of the liver affect the hepatocytes in the case of AIH and biliary epithelial cells in the case of PBC. Although select individuals can have features of both diseases, the clinical phenotypes and the immunological characteristics of these two diseases differ significantly $1,122,123$.

AIH has a strong female preponderance, affects all ages, sexes and races and responds well to immunosuppressive treatment. Immunosuppression has no benefit in patients with PBC, a disease which is rarely seen in men and children and is currently treated with ursodeoxycholic acid, a bile constituent ${ }^{122}$.

Genetic susceptibility associations with HLA and non-HLA genes have been noted in AIH but large genome wide association studies are still lacking. Contrary to $\mathrm{AIH}$, large genome wide studies have been conducted for PBC; a large number of loci have been found to be associated with disease, including HLA and non-HLA genes with immunological significance (such as that of IL12A, IL12RB, STAT4 and CTLA4) ${ }^{124-128}$. STAT4 has been identified in several previous studies, and is of interest given that it is closely involved with IL12 signalling and participates in the immunopathogenesis of autoimmune diseases.

Despite enormous efforts, the pathogenesis of both diseases remains poorly understood. Some progress has been made and major experimental findings in support of the involvement of the innate and the adaptive arm of immunity are presented ${ }^{123,129-131}$. Translational research on the immunopathogenesis of AIH focused on the role played by humoral responses against specific antigens, the involvement of conventional and unconventional T-cells, and the immunomodulatory role of Tregs. Attempts have also been made to identify environmental triggers of the disease and to develop animal models resembling the human condition. In PBC, credible antigen-specific animals models of the disease have been developed ${ }^{132-144}$. 


\section{Primary biliary cirrhosis}

$\mathrm{PBC}$ is a chronic cholestatic liver disease characterized by an inflammatory destruction of the medium-size and small intrahepatic bile ducts (Figure 5), which eventually leads to fibrosis, cirrhosis and liver failure ${ }^{122}$.

PBC was first recognized by Addison and Gull in 1851 but its nature became better understood in 1958 when Mackay reported a case with high titers of complement-fixing antibodies to tissue homogenates ${ }^{145}$; this autoantibody could be absorbed out using a mitochondrial fraction of rat liver ${ }^{146}$, and was present in the majority of patients ${ }^{147}$. The target antigens of these anti-mitochondrial antibodies (AMA) localized to the inner membrane of the mitochondria ${ }^{148}$. A major step forward in the study of PBC was the cloning of the major AMA target, the E2 subunit of the pyruvate dehydrogenase complex ${ }^{149,150}$. Subsequent studies identified as AMA antigens other E2 subunits of the 2oxo-acid dehydrogenase multienzyme family such as the branched-chain 2-oxo acid dehydrogenase complex (BCOADC) and 2-oxoglutarate dehydrogenase complex $(\mathrm{OGDC})^{151-156}$. Each of these three multifunctional complexes is involved in set of chain reactions and holds a key position in energy metabolism as PDC links glycolysis to the Krebs cycle, OGDC is essential to the Krebs cycle itself, and BCOADC is involved in the regulation of the oxidation of the branched-chain amino acids ${ }^{157,158}$.

Anti-PDC-E2 antibodies belong primarily to the IgG3 subclass, but IgM and $\operatorname{IgA}$ autoantibodies targeting this antigen can also be found. Autoantibodies to the 2-OADC enzymes are also detected in bile, saliva, and urine of patients with PBC ${ }^{159-161}$. Notably, high-titer AMAs in PBC sera can block in vitro the catalytic function of the 2-OAD multienzyme complexes and the AMA bound to PDC-E2 with the greatest affinity are effective in inhibiting PDC-E2 enzymatic activity ${ }^{162}$. The fine specificity of AMA within their respective antigens has been delineated ${ }^{150,163-169}$ and the core epitopic region on PDC-E2 has been mapped within the lipoyl domain of PDC-E2, though, at a 100-fold higher concentration, AMA also react with the outer domain ${ }^{170}$. AMA specific for BCOADC-E2 and OGDC-E2 are directed against conformational epitopes that include the inner lipoyl domain $^{171}$.

Adaptive Immunity in PBC-There is evidence of antigen-specific T-cell responses in $\mathrm{PBC}^{172,173}$. CD4 and CD8-T cell mapping studies have provided intriguing findings, as there is a major CD4 and CD8 epitope, which overlaps with the core B-cell epitope ${ }^{174-180}$. This overlap of the autoepitopic regions of B- and T-cells has promoted investigators to suggest that this bears a pathogenetic significance for the induction of PBC. This was especially the case after reports indicating that soluble PDC-E2 complexed with a PDC-E2specific human monoclonal antibody promotes the generation of PDC-E2-specific cytotoxic cells, at a 100-fold lower concentration than otherwise required in the presence of the soluble antigen alone ${ }^{177}$.

Apotopes and PBC-The basis for the selective autoimmune attack of BECs lining the medium and small-size intrahepatic bile ducts remains elusive. However, it is interesting that specific destruction of small intrahepatic bile ducts is a consequence of the unique 
characteristics of human intrahepatic BECs during apoptosis and can be explained by exposure to the immune system of intact immunoreactive PDC-E2 within apoptotic blebs ${ }^{181,182}$. After apoptosis, human intrahepatic biliary epithelial cells (HiBECs), but not other epithelial cells, translocate PDC-E2 immunologically intact into apoptotic bodies, forming apotopes ${ }^{182}$. This observation suggests that PDC-E2 is accessible to the immune system during apoptosis. Subsequent experiments demonstrated an intense inflammatory cytokine production in the presence of the unique triad of BEC apotopes, mature monocytederived macrophages macrophages from patients with $\mathrm{PBC}$, and AMAs ${ }^{181}$; other PBCspecific autoantigens also appear to be contained intact into apoptotic bodies appear to contain $^{183}$.

The role of innate immunity in PBC-The role of innate immunity in the immunopathogenesis of $\mathrm{PBC}$ has been supported by a plethora of experimental data demonstrating the intrinsic ability of cholangiocytes to express a variety TLRs, the cellular activators of innate immunity, or other PPRs ${ }^{184-188}$. Peroxisome proliferator-activated receptor $\gamma(\operatorname{PPAR} \gamma)$ is constitutively expressed in BECs isolated from small intrahepatic bile ducts. They appear to be downregulated in PBC bile ducts ${ }^{185}$. PBC is also characterized by an upregulation of TLR4 and TLR9 in cholangiocytes and of TLR3 and type I interferon gamma signaling pathways in portal tracts and parenchymal cells ${ }^{92,185}$.

A significant role for periductal Langerhans cells and biliary epithelial cell-derived macrophage inflammatory protein-3alpha ${ }^{184}$. Langerin-positive cells are predominantly within or scattered around biliary epithelial layers of bile ducts on liver biopsy specimens from $\mathrm{PBC}$ patients and may act as $\mathrm{APC}^{184}$. The close interaction of innate immunity cells with lymphoid cells with immunoregulatory importance has been strengthened by data demonstrating the induction and perpetuation of Th17 cells in the periductal area in cases of PBC and the differentiation into Th17 cells in periductal dendritic cells and macrophages ${ }^{189}$. It appears that in $\mathrm{PBC}$, there is a characteristic periductal accumulation of IL-17-positive mononuclear cells ${ }^{189}$. This is of interest given the wealth of experimental data from murine models of the disease based on the regulatory T-cell defects ${ }^{190,191}$.

\section{Autoimmune hepatitis}

Early data in patients with AIH ${ }^{192-195}$ suggested that the disease is characterized by diseasespecific circulating lymphocytes 'sensitized' to liver constituents of the so called liver soluble protein which were able to kill target cells in vitro. Subsequent experiments using separated T- and non-T- cell subsets from the peripheral blood of AIH patients and xenogenic target cells implies that cytotoxic cells were present in the non-T-cell subpopulation. The participation of antibody dependent cell-mediated cytotoxicity has been considered the most likely mechanism to explain the damage. Subsequent work has shown that IgG bound to hepatocytes are prone to injury by lymphocytes from healthy individuals ${ }^{196}$. However, clonal analysis studies clearly demonstrated that cytotoxicity against specific antigens of the liver is due to T-cells ${ }^{197}$. Further, CD4 T-cells have the capacity to initiate autoantibody production by autologous B lymphocytes ${ }^{197}$. Neutralization with antibodies specific for HLA-DR, CD4 and IL-2R abolishes the ability to produce autoantibodies ${ }^{197}$. 
Although there are serotypes of the disease characterized by autoimmune responses against poorly defined nuclear and smooth muscle autoantigens ${ }^{198-200}$, there are others (albeit less frequent) where the immune responses target liver-specific antigens ${ }^{194,201-206}$. Such an example is the immune response against cytochrome P450IID6 (CYP2D6), a member of the cytochrome $\mathrm{P} 450$ family of enzymes ${ }^{207}$. This is a family of exquisitely hepatic detoxifying enzymes, the most prevalent of those within the liver being the CYP3 and CYP2C families. It remains unclear as to why members of the CYP3 family are not target autoantigens in immune-mediated liver injuries. Also, peculiar to AIH is the fact that despite the high degree of homology between CYP2D6, CYP1A2 and CYP2A6 (Figure 12), antibodies against CYP2D6 do not cross-react with the two other cytochromes ${ }^{202,208,209}$. The overall homology of the three antigens is not restricted to amino acid similarity but is also present at the $3 \mathrm{D}$ level ${ }^{202}$ (Figure 12). The apparent lack of cross-recognition may be due to the fact that the epitopic regions recognized by individual anti-CYP antibodies are significantly dissimilar and can generate individual non cross-reactive humoral immune responses. This plausible explanation has been addressed experimentally for a limited number of peptides and proved to be valid ${ }^{210}$. The epitope specificity of antibodies against CYP2D6 has been delineated and the major linear epitopic regions appear to be exposed on the surface of the molecule (Figure 13).

Recent studies have identified the CD4 and CD8-T cell epitopes on CYP2D6 and have demonstrated a partial overlap of major $\mathrm{B}$-and $\mathrm{T}$-cell epitopic regions, a finding that has been described also before in studies for $\mathrm{PBC}^{211}$. T-cell clones generated from liver tissue and peripheral blood recognising a major B- and T-cell epitope (aa 262-285) appear to acquire a Th1 CD4 characterized by their ability to induce IFN $\gamma$ production phenotype ${ }^{211}$. Recent work has demonstrated the presence of HLA class I-restricted, IFN- $\gamma$-producing CYP2D6-specific CD8 T-cells ${ }^{212}$.

This has followed earlier studies demonstrating the presence of CD8 T-cell responses specifically recognizing the asialoglycoprotein receptor (ASGPR), a hepatic lectin the antigen recognition of which appears to be associated more with AIH than any other autoimmune or non-autoimmune liver disease.

Early publications provided hints in support of an impairment of suppressory lymphocyte populations in $\mathrm{AIH}^{213}, 214$ These findings have been recapitulated by new evidence supporting a numerical and functional impairment of Tregs which characterizes patients with $\mathrm{AIH}^{215-217}$. This evidence warranties external validation. Nevertheless, functionally enhanced Tregs can be expanded and generated de novo in patients with $\mathrm{AIH}^{217}$. This has been achieved using a polyclonal T-cell stimulation approach which is based on the use of exogenous IL-2 and the engages the T-cell receptor using CD3 and the co-stimulatory molecule CD28 217 .

\section{Alcoholic hepatitis (AH)}

AH is a syndrome characterized by infiltration of the liver by inflammatory cells, including neutrophils, and hepatocellular injury. In addition to the alcohol-induced hepatotoxicity and oxidative stress, activation of innate immunity involving TLR4 and complement also plays an important role in initiating $\mathrm{AH}$, but the role of adaptive immunity in the pathogenesis of 
AH remains largely unknown (Gao and Bataller, Gastroenterology, 2011,141:1572-85; Gao et al. Am J Physiol Gastrointest Liver Physiol. 2011;300:G516-25). The studies from last decade suggest that activation of a TLR4-mediated MyD88-independent (TRIF/IRF-3dependent) signaling pathway and complement system in the liver play an important role in the initiation and progression of AH (Gao et al. Am J Physiol Gastrointest Liver Physiol. 2011;300:G516-25). In contrast to activation of TLR4 and complement, chronic alcohol consumption can attenuate NK cells, another important innate immunity component, and subsequently abolish the anti-viral and anti-fibrotic effect of NK cells, contributing to alcohol-mediated acceleration of viral infection and liver fibrosis in patients with chronic viral hepatitis (Jeong et al., Gastroenterology. 2008;134:248-58).

Pathogen-induced Liver Immunity-To better understand the mechanisms responsible for the initiation of an efficient immune response against bacteria, we need to be able to separate anti-bacterial defense in the sinusoidal compartment versus that noted in the parenchymal compartment. Under normal conditions, pathogens circulating in the sinusoidal blood will be eliminated by resident immune cells and will prevent them from accessing or entering hepatocytes.

Bacterial infection targeting the liver-Early sensing of pathogens is important for the initiation of efficient innate immunity and the successful elimination of pathogens ${ }^{218-220}$. The adaptive arm of immunity also appears to play an important role in the induction of early anti-bacterial immunity 207,208 . Thus, KCs, NKT, NK and T cells collaborate in the eradication of pathogens in the sinusoidal blood ${ }^{219-222}$. Under normal conditions, KCs phagocytose bacteria leading to the rapid clearance of these bacteria from liver. KCs also present bacterial glycolipids on CD1 molecules to immune cells such as NKT ${ }^{218}$. Recent findings have demonstrated that KCs ingest Borrelia burgdorferi and induce chemokine receptor CXCR3-dependent clustering of invariant NKT cells ${ }^{218}$. KCs produce CXCL9 and other CXCR3 ligands in response to B. burgdorferi. The antigen-presenting molecule $\mathrm{C} 1 \mathrm{~d}$ allows for a stable contact of KCs and invariant NKTs in addition to activating NKTs. The attraction of NKT by KCs is achieved in a CXC-chemokine receptor 3-dependent manner ${ }^{218}$. Depletion of KCs prevents the formation of invariant NKT clusters. Also, the lack of KCS promotes a further increase of B. burgdorferi in liver parenchyma ${ }^{218}$. No internalization of spirochetes by LSECs has been noted, and the adherence spirochetes to LSECs is augmented when these cells are exposed to the pathogen and KCs are depleted ${ }^{218}$.

All together, these findings suggest that $B$. burgdorferi uses LSECs as a tool to escape resistance against pathogens provided by KCs in an attempt to gain access to the extravascular space ${ }^{218}$. Those Borrelia burgdorferi escaping KCs enter hepatocytes and survive despite initiation of immune responses by $\mathrm{HSCs}^{218}$. It seems that the cross-talk of KCs and NKT cells initiates an anti-bacterial immune response which prevents the host from persistent bacterial infection ${ }^{218}$. They also support the notion supported by data on Plasmodium yoelii, that KCs do not act as a portal for the entry of spirochetes into liver parenchyma 223 .

Granulomatous infections and liver immunity-Detection of granulomas in histological liver specimens is a relatively frequent finding, found in up to $4 \%$ of undivided 
samples analyzed ${ }^{224}$. In one of the largest studies conducted so far, evidence for granulomas was found in $442(3.6 \%)$ of 12,161 liver biopsies analyzed. The presence of infectious organisms was document in only 15 samples (3.4\%), with M. tuberculosis being detected in three of the 15 (20\%). Other mycobacteria, Yersinia, Toxoplasma gondii, Bartonella henselae and Listeria monocytogenes have also been considered responsible for the formation hepatic granulomas ${ }^{224-226}$. The exact mechanisms by which these infectious agents induce the development of giant cells and subsequent hepatic granulomas remain unclear $^{227}$. Granulomas mainly consist of focal accumulations of macrophages and the prevailing theory is that infection of macrophages plays an important role in the their formation ${ }^{227}$; the formation of granulomas is an attempt of the innate immune to control invasion of pathogens, especially when the adaptive arm of immunity is impaired. Listeria monocytogenes infection can induce the development of formatted by dendritic cells overexpressing indoleamine 2,3-dioxygenase ${ }^{227,228}$. The study of granulomas induced by mycobacterial infection has also revealed an important role for matrix metalloproteinase 9 expression in their formation ${ }^{229}$. Expression of this matrix metalloproteinase is required for the recruitment of macrophages and the formation of granulomas ${ }^{229}$.

Parasitic infections of the liver-Malarial transmission to humans is achieved by sporozoite infection of hepatocytes ${ }^{230}$. Infection with malarial parasites is an ideal model to study host-parasite interactions and the mechanisms that allow a pathogen to avoid elimination from immune cells, resident in the sinusoids, and subsequent hepatocyte infection $^{230-234}$. Work on animal models has provided a better understanding of the mechanisms responsible for parasite invasion. Sporozoites injected by mosquito bites enter the blood circulation, flow through liver sinusoids and subsequently infect hepatocytes, ${ }^{235-237}$ using poorly understood immune-mediated mechanisms.

Plasmodium spp. sporozoites appear to first target $\mathrm{KCs}^{238,239}$. Pradel and Frevert ${ }^{239}$ were the first to provide conclusive data suggesting that sporozoites selectively target and actively invade KCs to avoid the sinusoidal barrier. However, experiments on KC-depleted rats have demonstrated that such a depletion does not abrogate the ability of sporozoites to infect the hepatocytes ${ }^{234}$. Contrary to the these findings, subsequent experiments conducted by Baer et $\mathrm{al}^{223}$ have shown that $\mathrm{KC}$-deficient mice are resistant to sporozoite infection, probably because of the reduced number of portals to the liver parenchyma which prevents from direct access to hepatocytes. Recent data suggests that circumsporozoite protein, the sporozoite's major surface protein, has an adhesive confirmation in which the C-terminal cell-adhesive domain is exposed and a non-adhesive conformation in which the $\mathrm{N}$ terminus covers this domain, the former being important for hepatocyte invasion ${ }^{240}$. The state of hepatocytes also appears to play an important role for sporozoite infectivity; hepatocytes over-expressing the CD81, a tetraspanin which has been regarded as receptor for hepatitis C virus entry to hepatocytes, are susceptible to infection by Plasmodium falciparum and Plasmodium yoelli ${ }^{241}, 242$. Subsequent findings have indicated that CD81 may not interact directly with the ligand of Plasmodium yoelli during Plasmodium infection, but through an unidentified protein which is regulated by $\mathrm{CD} 81^{241}$.

In endemic areas, repeated exposure to sporozoites during infection does not always lead to the clearance of the parasite from the circulation. This is probably due to the lack of 
protective immunity 243,244 manifested as antigen-specific antibody and CD8 ${ }^{+} \mathrm{T}$ cell responses targeting the circumsporozoite protein, which is one of the most immunodominant targets of malaria-specific immunity ${ }^{245}$. The number of Plasmodium-specific memory CD8 $\mathrm{T}$ cells required for immunity greatly exceeds the number required for resistance to other pathogens ${ }^{244,246}$. Also, IL-4 secreting $\mathrm{CD}^{+} \mathrm{T}$ cells appear important for the development of $\mathrm{CD}^{+} \mathrm{T}$-cell responses against malaria liver stages ${ }^{247}$. If $\mathrm{CD} 4^{+} \mathrm{T}$ cell are absent, $\mathrm{CD} 8^{+} \mathrm{T}$ cells responses are reduced by $90 \%$ compared to that seen in the presence of $\mathrm{CD} 4^{+} \mathrm{T}$ cells and the cell-cell interaction largely depends on the presence of IL-4 247 .

Viral Hepatitides-Hepatitis B and C viruses (HBV and HCV) are the most common infectious causes of chronic liver disease worldwide. More than 500 million people are infected with HBV and HCV worldwide, and a significant proportion of those develop chronic liver disease, with mortality predominantly from the complication of cirrhosis and from hepatocellular carcinoma ${ }^{248,249}$. HBV and HCV are members of the hepadnaviridae and flaviridae families, respectively. The half-life of HBV is 2-3 days, while that of HCV is approximately 3 hours. An effective vaccine for the prevention of HBV has been available for years, but such a vaccine does not currently exist for HCV. Hepatitis A and E are foodborne RNA viruses, which infect the liver when they reach the blood through transversing gut epithelial cells 250,251 . They are transmitted from person-to-person by ingestion of contaminated water or food or water or through direct contact with an infected individual. Their incidence is high in developing countries, and both can cause acute hepatitis.

Virus-specific immunity has been considered responsible for the clearance of the virus and protective immunity but also for the immune-mediated destruction of hepatocytes and the development of cirrhosis ${ }^{252-254}$. The study of the immunobiology of these viruses has been hampered by the lack of well-defined small animal models that accurately resemble the human disease $\mathrm{255}^{258}$. Virus-host interactions have been studied in the chimpanzee model (the only animal that can be infected with both viruses) and in translational research projects using biological material from infected individuals $252,253,259-264$. From these studies it has become apparent that HBV and HCV share in common various immunopathologic features, but are highly variable in their virologic properties and kinetics during acute and chronic infection. They also differ in their viral- immune evasion and survival tactics ${ }^{219,} 253$.

While perinatal HBV infection normally leads to chronic hepatitis, $90 \%$ or more of the acutely infected adults resolve from symptoms, develop virus-specific antibodies and preserve lifelong protective immunity. T-cell mediated liver destruction manifested as an increase of serum alanine aminotransferase is seen 10-15 weeks after infection. Humans and chimpanzees infected with HCV develop adaptive cellular and humoral responses only after at least 1 month and 2 months, respectively, after the infection ${ }^{265,266}$. An increase of transaminases levels is noted 8-12 weeks after infection with $\mathrm{HCV}$.

Innate immune responses in viral hepatitides-A wealth of experimental data in infected chimpanzees has provided a better understanding of the role of innate immunity in the early phases of the infection ${ }^{252,267-270}$. The study of the chimpanzee model has shown that HBV DNA is cleared from the serum and the livers of the infected animals long before the development of significant anti-viral adaptive immunity ${ }^{252}$. Work on transgenic mice 
has shown that IFN- $\gamma$ produced by NKT cells can significantly suppress HBV replication ${ }^{271}, 272$. Also, type I IFNs produced by KCs and other innate immune cells play a major role in the control of viral replication and spreading to neighbouring hepatocytes ${ }^{273-275}$; such IFNs also prevent the induction of severe immune-mediated hepatocyte destruction ${ }^{273-275}$. These data have prompted investigators to consider an important role for innate immunity in controlling virus replication ${ }^{271,272}$. Genetic microarray analyses in sequential liver samples from HBV infected chimpanzees have failed to show remarkable changes in the expression of type I IFN ${ }^{268}$ leading to the assumption that the inability to provoke strong innate immune responses in the first weeks of infection is an evasion strategy used by the virus in order to persist. KCs appear to control, to some extent, the magnitude of innate responses, both in HBV and HCV. Capsid proteins of these viruses trigger the expression of TLR-1, TLR-2 and TLR-6 expression on KCs and the subsequent release of pro-inflammatory and regulatory cytokines ${ }^{276-278}$, involving various PPRs in cellular activation by viral proteins.

Despite the lack of strong innate responses, the recovery rate following HBV infection remains paradoxically very high. On the other hand, HCV infection provokes early changes in the expression of type I IFN and other genes ${ }^{269}$. The fact that HCV infected patients, who are homozygous for certain killer cell immunoglobulin-like receptor haplotypes are more likely to clear the virus and recover from HCV infection adds strength to the notion innate immunity is required for an efficient control of the virus ${ }^{279}$.

These data demonstrate that HBV and HCV are highly sensitive to type I IFN ${ }^{280-282}$ and this has been the basis for the treatment of chronically infected patients, which is based on the administration of IFN-a, alone or in combination with anti-viral agents. Specific genetic polymorphisms in the IL28B locus predict a favourable outcome and response to IFN$a^{283-288}$. It also appears that the induction of strong immune responses at early stages of the infection predicts a more favourable outcome and indicates subsequent clearance of $\mathrm{HCV}^{289}$. Against this background, it has become apparent that initiation of strong innate immune responses per se does not immediately preclude the clearance of $\mathrm{HCV}$, as viral chronicity is established in more $50 \%$ of cases.

\section{Hepatocyte receptors of hepatotropic viruses and innate immunity-The} attachment of HBV and HCV to hepatocytes requires cross-linking with heparin sulphate proteoglycans. Clear demonstration of a molecule which can serve as a receptor for HBV has not been provided. None of the molecules reported so far as receptors of HCV are hepatocyte-specific. The tetraspin CD81 was amongst the first molecules to be identified as hepatocyte receptors of $\mathrm{HCV}^{290}$.

Other molecules which can bind to HCV and seem important for the internalization of HCV into hepatocytes include the low density lipoprotein receptor ${ }^{291}$ and the scavenger receptor $\mathrm{B} 1^{292}$. Also, the envelope $\mathrm{E} 2$ protein of $\mathrm{HCV}$ can bind to the liver and lymph-node specific ICAM3 grabbing non-integrin (L-SIGN) which is also expressed by LSECs and the DCspecific ICAM3 grabbing non-integrin (D-SIGN) which is also expressed by KCs ${ }^{293-297}$. Claudin-1298, occludin ${ }^{299}$, the epidermal growth factor receptor and ephrin type A receptor $2^{300}$ are also co-receptors of HCV and play a role in the late steps of viral entry. It appears, 
that when $\mathrm{HCV}$ reaches the liver attached to heparin sulphate proteoglycans in liver sinusoids, it binds to low density lipoprotein, CD81 or scavenger receptor B1 and before endocytosis attaches to claudin and occludin. The receptor tyrosine kinases epidermal growth factor receptor and ephrin type A receptor mediate HCV entry by regulating CD81claudin-1 co-receptor interactions.

The role of the HCV receptors is not limited to the entry of the virus into hepatocytes. They appear to alter host-virus innate immunity responses with mechanisms poorly understood. Thus, binding of HCV envelope 2 protein with NKs expressing CD81 inhibits the production of IFN- $\gamma$ and other pro-inflammatory cytokines and suppresses their cytotoxic effects innate immune cells expressing CD81 can alter host-virus innate immunity 301302,303 (Figure 14). Collectively, these data demonstrate that the cytotoxic potential of NK cells from healthy individuals is impaired in the presence of high concentrations of $\mathrm{HCV}$ envelope 2 protein, and that NKs from patients infected with $\mathrm{HCV}$ are unable to produce pro-inflammatory cytokines and to activate $\mathrm{DCs}^{301302,303}$. Such findings may not be limited to CD81-mediated HCV/NK interactions but may include other innate immune cells.

A mucin-like class I integral membrane glycoprotein has been considered the attachment receptor of $\mathrm{HAV}^{304,305}$. Anti-HAV specific antibodies of the IgA class can carry the virus. Asialoglycoprotein receptor is a C-type lectin which clears IgA from the circulation ${ }^{306,307 .}$ Anti-HAV specific IgA antibodies use asialoglycoprotein receptor to infect hepatocytes ${ }^{308}$. Dotzauer et al ${ }^{308}$ used a mouse hepatocyte model which, because it does not permit infection with HAV, can be used as a model to study carrier-mediated HAV entry into host cells without any interference by the HAV receptors. These authors have shown that HAV is taken up by hepatocytes in the form of HAV-specific IgA immunocomplexes and are endocytosed by ASGPR. This has led Protzer et al to hypothesize that KCs expressing the Fca receptor ${ }^{309}$ may bind the IgA-HAV complexes ${ }^{219}$. They may then transfer these complexes to hepatocytes, where the virus can be internalized via the asialoglycoprotein receptor $^{219}$.

\section{Adaptive immune responses in viral hepatitis $\mathbf{B}$ and $\mathbf{C}-$ Neither HBV nor HCV} clearance can be sustained through the development of strong innate immunity. It appears that the elimination of these viruses can only be achieved in the presence of strong antigenspecific $\mathrm{CD}^{+}$and $\mathrm{CD} 8^{+} \mathrm{T}$ cell responses, a finding that clearly supports the thesis that the adaptive arm of immunity is the most critical for the immune-mediated clearance of the virus $^{281,310,311 .}$.

Humoral Immunity-The isotype and antigen-specificity of antibody responses in acute and chronic HBV indicates the stage of the disease. IgM antibodies against the hepatitis B core antigen are early markers of infection. Acutely infected patients who recover develop neutralizing antibodies against hepatitis surface antigen (and antigen-specific $\mathrm{CD} 4^{+}$and $\mathrm{CD} 8^{+} \mathrm{T}$-cell responses against the core and other antigens of the DNA virus) that confer lifelong protection. The great majority of virus-free individuals who are vaccinated with the surface antigen develop high-titer neutralizing antibodies and are protected from exposure to HBV. Recent data has demonstrated reactivation of the disease following B-cell depletion, indicating the importance of these cells in controlling the virus ${ }^{312}$. 
Chronic HBV infection is roughly subdivided in the immunotolerant, immunoreactive, low replicative and high replicative phases. The duration of these stages varies amongst infected individuals. Antibodies against hepatitis e and surface antigens appear late and are signs of a favorable course while the presence of antibodies against the core and the surface antigens are present forever after the resolution of clinical symptoms.

The influence of anti-HCV antibodies over the course of the disease is far from clear. Infection with $\mathrm{HCV}$ does not initiate early humoral responses and the highest concentrations of anti-HCV antibody responses are typically present in patients with well-established chronic HCV infection. In contrast, patients who recovered from HCV do not have detectable anti-HCV antibodies, a finding that has prompted investigators to consider the emergence of $\mathrm{HCV}$ escape mutants. How HCV constantly evades neutralizing antibodies during chronic infection remains unclear, though it is most likely due to its ability to 'creep' from one hepatocyte to another (cell-to-cell transmission) and to generate a selection of escape mutants are the most likely scenarios. ${ }^{313,314}$.

Cellular immunity against hepatitis B and C-The study of the immunobiology of $\mathrm{HBV}$ and HCV has led to the appreciation that persistent infection is largely due to the inability of the immune system to clear the virus. Depletion and exhaustion of cytotoxic T lymphocytes specific for viral antigens is the main cause for the inability to control the virus. Antigen-specific cytotoxic lymphocytes are prone to apoptosis ${ }^{315}$. Also, HCV-specific $\mathrm{CD} 8^{+} \mathrm{T}$ cells undergo substantial apoptosis in the periphery during acute $\mathrm{HCV}$ infection and in the liver during chronic infection ${ }^{316}$. BCL-2-Interacting Mediator, a key pro-apoptotic mediator which is known as BIM, plays an important role in the apoptosis of virus-specific $\mathrm{CD}^{+} \mathrm{T}$ cells ${ }^{315,317}$. Consistent exposure to antigenic overload during infection leads to the 'exhaustion' of cytotoxic T lymphocytes ${ }^{318,319}$. This phenomenon is largely mediated through the programmed death PD-1/PD-L1 T cell co-inhibitory pathway. PD-1 is a coinhibitory molecule that controls T-cell reactivity. PD-L1 and PD-L2 binding to the PD-1 receptor negatively regulates $\mathrm{T}$ cells, leading to decreased proliferation and down-regulation of IL-2 and IFN- $\gamma$. This 'exhaustion' operates at several levels and allows the virus to escape immune recognition and to establish persistent infection ${ }^{320}$. Blocking PD-1 restores intrahepatic HBV-specific T-cell responses ${ }^{321,322}$. This may explain why HBV patients have over-expressed PD-1 compared to healthy individuals ${ }^{322}$. Also, HCV-specific cytotoxic T lymphocytes that are phenotypically exhausted are characterized by PD-1 overexpression ${ }^{323,324}$. Patients with chronic HBV and HCV infection over-express co-inhibitory molecules such as PD-1, CTL4, T cell immunoglobulin domain protein 3 and 2B4 ${ }^{325}$. An imbalance on the operation of co-inhibitory pathways in viral hepatitides $\mathrm{B}$ and $\mathrm{C}$ appears not to be limited at the lymphocyte level, as it includes KCs LSECs and HSCs. These cells appear to express (at least) PD-L1, and their induction has been demonstrated during viral infection ${ }^{71}, 106,326-331$. The role of $\mathrm{CD}^{+} \mathrm{T}$ cells has been extensively studied in patients and chimpanzees infected with HBV or HCV. These studies have shown that induction of vigorous, antigen-specific CD4 $\mathrm{T}$ cell responses positively correlates with the recovery from the infection ${ }^{332}$. Epitope mapping studies have delineated the disease-specific autopepitopic regions recognized by acutely and chronically infected patients at various phases of the diseases $^{254}$. Despite the low frequency of $\mathrm{CD}^{+} \mathrm{T}$ cells in the periphery, flow cytometric 
analyses have shown that in the early phase of the infection with $\mathrm{HCV} \mathrm{CD} 4^{+} \mathrm{T}$ cell become detectable at the time $\mathrm{CD} 8^{+} \mathrm{T}$ cell recover ${ }^{266}$. The close interplay between $\mathrm{CD} 4^{+}$and $\mathrm{CD} 8^{+}$ $\mathrm{T}$ cells has been shown in studies indicating that CD4 depletion from a chimpanzee recovered from $\mathrm{HCV}$ infection leads to the loss of protective immunity upon re-exposure to the virus ${ }^{311}$. These studies have provided data to suggest that $\mathrm{CD} 4^{+} \mathrm{T}$ cells confer protective immunity but are also participating the induction of immune-mediated hepatocyte destruction.

Extrahepatic immune-mediated manifestations are frequently seen in chronic HBV and $\mathrm{HCV}$. In the great majority of the cases are manifested as low to medium titer autoantibodies against nuclear and smooth muscle antibodies ${ }^{333}$. Whether these autoantibodies are induced as a result of polyclonal B-expansion during hepatocyte destruction or they are the outcome of antigen-driven mechanisms such as molecular mimicry and immunological crossreactivity remains elusive $202,208,333-338$. Immune complex-mediated rheumatic manifestations, mixed cryoglobulinemia, and non-Hodgkin lymphomas are more frequently seen in chronic $\mathrm{HCV}$ infected patients than $\mathrm{HBV}^{339}$. Viral-induced autoimmune liver diseases are rarely noted, and a link between the virus and the autoimmune condition is difficult to make $\mathrm{e}^{340-342}$.

The immunopathology of hepatocellular carcinoma-It has become apparent that while a vigorous antigen-specific immune response against HBV and HCV leads to viral clearance, the depletion and exhaustion of cytotoxic T lymphocytes specific for viral antigens induces chronic hepatitis and subsequent cirrhosis. In an attempt to respond to the process of necroinflammation, the liver regenerates, and in this process activates macrophages which release free radical with carcinogenic potential. The concert action of mitogenic and mutagenic stimuli causing cellular and DNA damage and the dysregulation of cellular growth leads to the development of hepatocellular carcinoma ${ }^{343,344}$. HBV vaccination programs prevented the development of newly infected cases and indirectly decreased the number of new hepatocellular carcinoma cases ${ }^{345}$. In this respect, the hepatitis $B$ vaccine can be considered one of the very first successful immunotherapy cancer vaccines.

Tumor markers such as alpha fetoprotein are increased during the course of hepatocarcinogenesis and T-cell responses specific for this antigen are present in the peripheral blood of patients with cancer ${ }^{346-349}$. Several other antigens have been identified as potential tumor markers and target autoantigens but none of them is highly diseasespecific. Nevertheless, strong tumor-specific $\mathrm{CD} 8^{+} \mathrm{T}$ cell responses control tumor progression and prevent from the recurrence of hepatocellular carcinoma ${ }^{350,351}$. Several studies have shown that tumors have adopted numerous immune escape mechanisms, that include the induction of immunosuppressory cells. These include regulatory $\mathrm{T}$ cells and myeloid-derived suppressor cells. Such cells have the potential to mask tumor-specific immune responses in patients with hepatocellular carcinoma.

The frequency of circulating CD4(+)CD25(+)FoxP3(+) Treg is increased significantly in patients with hepatocellular carcinoma compared to controls and correlated with disease progression ${ }^{352,353}$. Clustering of Tregs and reduction rates of infiltration $\mathrm{CD} 8^{+} \mathrm{T}$ cells are 
characteristically found in tumor regions compared with nontumor regions and these Tregs suppress the anti-CD3/CD28 induced cytolytic activity of $\mathrm{CD} 8^{+} \mathrm{T}$ cells ${ }^{352}$. Current attempts concentrate in targeting regulatory $\mathrm{T}$ cells as this will potentially enhance tumor-specific $\mathrm{CD}^{+} \mathrm{T}^{\mathrm{T}}$ cells ${ }^{354,355}$.

\section{Conclusions}

Historically, the immune system was divided into mucosal versus systemic immunity. While this division is still accurate, it is equally important to note specific immunological contributions of specific organs; this is illustrated not only by the liver as discussed herein, but also with respect to skin, lung and other tissues. We have not attempted to discuss loss of tolerance in the detail deserved in a paper devoted to liver and the immune response and we refer to a number of recent publications which deal specifically with genetics, environment and immunity $356-375$. However, it is noteworthy that the liver is anatomically unique and its function is essential for fetal tolerance and host protection from gut flora and the enormous repertoire of materials that pass through the portal circulation. It is indeed ironic that the liver, which is so critical for immune tolerance, can itself become a victim in diseases such as autoimmune hepatitis and primary biliary cirrhosis. We have not discussed primary sclerosing cholangitis herein because the scope is far beyond that of the thesis herein. However, it also brings to mind great voids that exist with respect to our knowledge on chemokines and their cognate receptors with respect to lymphoid homing and we refer to a number of seminal publications by Adams and colleagues ${ }^{376-380}$. Finally, there is also the hope that the liver as a facilitator of tolerance can be used as a tolerizing vehicle to restore immune homeostasis in other examples of human autoimmune disease ${ }^{381}$.

\section{Abbreviations}

AIH Autoimmune hepatitis

AMA Antimitochondrial antibody

ANA Antinuclear antibody

APC Antigen presenting cell

DC Dendritic cell

HSC Hepatic stellate cell

IFN Interferon

IL Interleukin

MHC Major Histocompatibility Complex

KC Kupffer cell

LPS Lipopolysaccharide endotoxin

LSEC Liver sinusoidal endothelial cell

mDC myeloid DC 


$\begin{array}{ll}\text { NK } & \text { Natural Killer } \\ \text { NKT } & \text { Natural Killer T-cell } \\ \text { OADC } & \text { oxo-acid dehydrogenase complex } \\ \text { OGDC } & \text { 2-oxoglutarate dehydrogenase complex } \\ \text { PAMP } & \text { pathogen-associated molecular pattern } \\ \text { PBC } & \text { primary biliary cirrhosis } \\ \text { PD } & \text { programmed death } \\ \text { pDC } & \text { plasmacytoid DC } \\ \text { PD-L1 } & \text { programmed death ligand 1 } \\ \text { PPR } & \text { Pattern recognition patterns } \\ \text { TLR } & \text { Toll-like receptor }\end{array}$

\section{References}

1. Kita H, Mackay IR, Van De Water J, Gershwin ME. The lymphoid liver: considerations on pathways to autoimmune injury. Gastroenterology. 2001; 120:1485-1501. [PubMed: 11313320]

2. Starzl TE, Marchioro TL, Vonkaulla KN, Hermann G, Brittain RS, Waddell WR. Homotransplantation of the Liver in Humans. Surg Gynecol Obstet. 1963; 117:659-676. [PubMed: 14100514]

3. Calne RY, Rolles K, White DJ, Thiru S, Evans DB, McMaster P, Dunn DC, Craddock GN, Henderson RG, Aziz S, Lewis P. Cyclosporin A initially as the only immunosuppressant in 34 recipients of cadaveric organs: 32 kidneys, 2 pancreases, and 2 livers. Lancet. 1979; 2:1033-1036. [PubMed: 91781]

4. Zimmermann FA, White DJ, Gokel JM, Calne RY. Orthotopic liver transplantation in rats. Prolonging of survival time of allotransplants using cyclosporin A in an acute rejection model. Chir Forum Exp Klin Forsch. 1979:339-344. [PubMed: 378595]

5. Calne RY, Sells RA, Pena JR, Davis DR, Millard PR, Herbertson BM, Binns RM, Davies DA. Induction of immunological tolerance by porcine liver allografts. Nature. 1969; 223:472-476. [PubMed: 4894426]

6. Cantor HM, Dumont AE. Hepatic suppression of sensitization to antigen absorbed into the portal system. Nature. 1967; 215:744-745. [PubMed: 6059543]

7. Blouin A, Bolender RP, Weibel ER. Distribution of organelles and membranes between hepatocytes and nonhepatocytes in the rat liver parenchyma. A stereological study. J Cell Biol. 1977; 72:441455. [PubMed: 833203]

8. Bolender RP, Weibel ER. A morphometric study of the removal of phenobarbital-induced membranes from hepatocytes after cessation of threatment. J Cell Biol. 1973; 56:746-761. [PubMed: 4569312]

9. Loud AV. A quantitative stereological description of the ultrastructure of normal rat liver parenchymal cells. J Cell Biol. 1968; 37:27-46. [PubMed: 5645844]

10. Weibel ER, Staubli W, Gnagi HR, Hess FA. Correlated morphometric and biochemical studies on the liver cell. I. Morphometric model, stereologic methods, and normal morphometric data for rat liver. J Cell Biol. 1969; 42:68-91. [PubMed: 4891915]

11. Staubli W, Hess R, Weibel ER. Correlated morphometric and biochemical studies on the liver cell. II. Effects of phenobarbital on rat hepatocytes. J Cell Biol. 1969; 42:92-112. [PubMed: 4306789] 
12. Gumucio, JJ.; Berkovitz, CM.; Webster, ST.; Thornton, AJ. Structural and functional organization of the liver. In: Kaplowitz, N., editor. Liver and biliary diseases. Vol. II. Baltimore: Williams \& Wilkins; 1996. p. 3-19.

13. Rappaport AM, Borowy ZJ, Lougheed WM, Lotto WN. Subdivision of hexagonal liver lobules into a structural and functional unit; role in hepatic physiology and pathology. Anat Rec. 1954; 119:11-33. [PubMed: 13180999]

14. Freudenberg MA, Freudenberg N, Galanos C. Time course of cellular distribution of endotoxin in liver, lungs and kidneys of rats. Br J Exp Pathol. 1982; 63:56-65. [PubMed: 7039654]

15. Elvevold K, Smedsrod B, Martinez I. The liver sinusoidal endothelial cell: a cell type of controversial and confusing identity. Am J Physiol Gastrointest Liver Physiol. 2008; 294:G391G400. [PubMed: 18063708]

16. Wisse E. An electron microscopic study of the fenestrated endothelial lining of rat liver sinusoids. J Ultrastruct Res. 1970; 31:125-150. [PubMed: 5442603]

17. Braet F, de Zanger R, Seynaeve C, Baekeland M, Wisse E. A comparative atomic force microscopy study on living skin fibroblasts and liver endothelial cells. J Electron Microsc (Tokyo). 2001; 50:283-290. [PubMed: 11592673]

18. Braet F, Kalle WH, De Zanger RB, De Grooth BG, Raap AK, Tanke HJ, Wisse E. Comparative atomic force and scanning electron microscopy: an investigation on fenestrated endothelial cells in vitro. J Microsc. 1996; 181:10-17. [PubMed: 8627618]

19. Fraser R, Dobbs BR, Rogers GW. Lipoproteins and the liver sieve: the role of the fenestrated sinusoidal endothelium in lipoprotein metabolism, atherosclerosis, and cirrhosis. Hepatology. 1995; 21:863-874. [PubMed: 7875685]

20. Knolle PA, Gerken G. Local control of the immune response in the liver. Immunol Rev. 2000; 174:21-34. [PubMed: 10807504]

21. Crispe IN. Liver antigen-presenting cells. J Hepatol. 2011; 54:357-365. [PubMed: 21084131]

22. Thomson AW, Knolle PA. Antigen-presenting cell function in the tolerogenic liver environment. Nat Rev Immunol. 2010; 10:753-766. [PubMed: 20972472]

23. Norris S, Collins C, Doherty DG, Smith F, McEntee G, Traynor O, Nolan N, Hegarty J, O'Farrelly C. Resident human hepatic lymphocytes are phenotypically different from circulating lymphocytes. J Hepatol. 1998; 28:84-90. [PubMed: 9537869]

24. Norris S, Doherty DG, Collins C, McEntee G, Traynor O, Hegarty JE, O'Farrelly C. Natural T cells in the human liver: cytotoxic lymphocytes with dual $\mathrm{T}$ cell and natural killer cell phenotype and function are phenotypically heterogenous and include Valpha24-JalphaQ and gammadelta T cell receptor bearing cells. Hum Immunol. 1999; 60:20-31. [PubMed: 9952024]

25. Doherty DG, Norris S, Madrigal-Estebas L, McEntee G, Traynor O, Hegarty JE, O'Farrelly C. The human liver contains multiple populations of NK cells, T cells, and CD3+CD56+ natural T cells with distinct cytotoxic activities and Th1, Th2, and Th0 cytokine secretion patterns. J Immunol. 1999; 163:2314-2321. [PubMed: 10438977]

26. Hata K, Zhang XR, Iwatsuki S, Van Thiel DH, Herberman RB, Whiteside TL. Isolation, phenotyping, and functional analysis of lymphocytes from human liver. Clin Immunol Immunopathol. 1990; 56:401-419. [PubMed: 1697226]

27. Doherty DG, O'Farrelly C. Innate and adaptive lymphoid cells in the human liver. Immunol Rev. 2000; 174:5-20. [PubMed: 10807503]

28. Ohteki T, Abo T, Seki S, Kobata T, Yagita H, Okumura K, Kumagai K. Predominant appearance of gamma/delta T lymphocytes in the liver of mice after birth. Eur J Immunol. 1991; 21:17331740. [PubMed: 1829415]

29. Abo T, Watanabe H, Iiai T, Kimura M, Ohtsuka K, Sato K, Ogawa M, Hirahara H, Hashimoto S, Sekikawa H, et al. Extrathymic pathways of T-cell differentiation in the liver and other organs. Int Rev Immunol. 1994; 11:61-102. [PubMed: 8057045]

30. Hayakawa S, Saito S, Nemoto N, Chishima F, Akiyama K, Shiraishi H, Hayakawa J, KarasakiSuzuki M, Fujii KT, Ichijo M, et al. Expression of recombinase-activating genes (RAG-1 and 2) in human decidual mononuclear cells. J Immunol. 1994; 153:4934-4939. [PubMed: 7963556]

31. Rocha B, Vassalli P, Guy-Grand D. Thymic and extrathymic origins of gut intraepithelial lymphocyte populations in mice. J Exp Med. 1994; 180:681-686. [PubMed: 8046341] 
32. Brandes M, Willimann K, Moser B. Professional antigen-presentation function by human gammadelta T Cells. Science. 2005; 309:264-268. [PubMed: 15933162]

33. Carding SR, Egan PJ. Gammadelta T cells: functional plasticity and heterogeneity. Nat Rev Immunol. 2002; 2:336-345. [PubMed: 12033739]

34. Zhao N, Hao J, Ni Y, Luo W, Liang R, Cao G, Zhao Y, Wang P, Zhao L, Tian Z, Flavell R, Hong Z, Han J, Yao Z, Wu Z, Yin Z. Vgamma4 gammadelta T cell-derived IL-17A negatively regulates NKT cell function in Con A-induced fulminant hepatitis. J Immunol. 2011; 187:5007-5014. [PubMed: 21987663]

35. Hamada S, Umemura M, Shiono T, Tanaka K, Yahagi A, Begum MD, Oshiro K, Okamoto Y, Watanabe H, Kawakami K, Roark C, Born WK, O'Brien R, Ikuta K, Ishikawa H, Nakae S, Iwakura Y, Ohta T, Matsuzaki G. IL-17A produced by gammadelta T cells plays a critical role in innate immunity against listeria monocytogenes infection in the liver. J Immunol. 2008; 181:34563463. [PubMed: 18714018]

36. He W, Hao J, Dong S, Gao Y, Tao J, Chi H, Flavell R, O'Brien RL, Born WK, Craft J, Han J, Wang P, Zhao L, Wu J, Yin Z. Naturally activated V gamma 4 gamma delta T cells play a protective role in tumor immunity through expression of eomesodermin. J Immunol. 2010; 185:126-133. [PubMed: 20525896]

37. Hao J, Dong S, Xia S, He W, Jia H, Zhang S, Wei J, O'Brien RL, Born WK, Wu Z, Wang P, Han J, Hong Z, Zhao L, Yin Z. Regulatory role of Vgamma1 gammadelta T cells in tumor immunity through IL-4 production. J Immunol. 2011; 187:4979-4986. [PubMed: 21987661]

38. Martins EB, Graham AK, Chapman RW, Fleming KA. Elevation of gamma delta T lymphocytes in peripheral blood and livers of patients with primary sclerosing cholangitis and other autoimmune liver diseases. Hepatology. 1996; 23:988-993. [PubMed: 8621180]

39. Wen L, Ma Y, Bogdanos DP, Wong FS, Demaine A, Mieli-Vergani G, Vergani D. Pediatric autoimmune liver diseases: the molecular basis of humoral and cellular immunity. Curr Mol Med. 2001; 1:379-389. [PubMed: 11899084]

40. Wen L, Peakman M, Mieli-Vergani G, Vergani D. Elevation of activated gamma delta T cell receptor bearing $\mathrm{T}$ lymphocytes in patients with autoimmune chronic liver disease. Clin Exp Immunol. 1992; 89:78-82. [PubMed: 1385768]

41. Ferri S, Longhi MS, De Molo C, Lalanne C, Muratori P, Granito A, Hussain MJ, Ma Y, Lenzi M, Mieli-Vergani G, Bianchi FB, Vergani D, Muratori L. A multifaceted imbalance of T cells with regulatory function characterizes type 1 autoimmune hepatitis. Hepatology. 2010; 52:999-1007. [PubMed: 20683931]

42. Murison JG, Quaratino S, Kahan M, Verhoef A, Londei M. Definition of unique traits of human CD4-CD8- alpha beta T cells. Clin Exp Immunol. 1993; 93:464-470. [PubMed: 8370176]

43. Niehues T, Gulwani-Akolkar B, Akolkar PN, Tax W, Silver J. Unique phenotype and distinct TCR $\mathrm{V}$ beta repertoire in human peripheral blood alpha beta TCR+, CD4-, and CD8- double negative T cells. J Immunol. 1994; 152:1072-1081. [PubMed: 8301117]

44. Thomson CW, Lee BP, Zhang L. Double-negative regulatory T cells: non-conventional regulators. Immunol Res. 2006; 35:163-178. [PubMed: 17003518]

45. Thomson CW, Teft WA, Chen W, Lee BP, Madrenas J, Zhang L. FcR gamma presence in TCR complex of double-negative T cells is critical for their regulatory function. J Immunol. 2006; 177:2250-2257. [PubMed: 16887985]

46. Masuda T, Ohteki T, Abo T, Seki S, Nose S, Nagura H, Kumagai K. Expansion of the population of double negative CD4-8- T alpha beta-cells in the liver is a common feature of autoimmune mice. J Immunol. 1991; 147:2907-2912. [PubMed: 1833460]

47. von Boehmer H, Kirberg J, Rocha B. An unusual lineage of alpha/beta T cells that contains autoreactive cells. J Exp Med. 1991; 174:1001-1008. [PubMed: 1834758]

48. Selmi C, Mackay IR, Gershwin ME. The immunological milieu of the liver. Semin Liver Dis. 2007; 27:129-139. [PubMed: 17520513]

49. Crispe IN. The liver as a lymphoid organ. Annu Rev Immunol. 2009; 27:147-163. [PubMed: 19302037] 
50. Vivier E, Raulet DH, Moretta A, Caligiuri MA, Zitvogel L, Lanier LL, Yokoyama WM, Ugolini S. Innate or adaptive immunity? The example of natural killer cells. Science. 2011; 331:44-49. [PubMed: 21212348]

51. Ishihara S, Nieda M, Kitayama J, Osada T, Yabe T, Ishikawa Y, Nagawa H, Muto T, Juji T. CD8(+)NKR-P1A (+)T cells preferentially accumulate in human liver. Eur J Immunol. 1999; 29:2406-2413. [PubMed: 10458753]

52. Bertolino P, McCaughan GW, Bowen DG. Role of primary intrahepatic T-cell activation in the 'liver tolerance effect'. Immunol Cell Biol. 2002; 80:84-92. [PubMed: 11869365]

53. Qian S, Demetris AJ, Murase N, Rao AS, Fung JJ, Starzl TE. Murine liver allograft transplantation: tolerance and donor cell chimerism. Hepatology. 1994; 19:916-924. [PubMed: 8138266]

54. Li W, Kuhr CS, Zheng XX, Carper K, Thomson AW, Reyes JD, Perkins JD. New insights into mechanisms of spontaneous liver transplant tolerance: the role of Foxp3-expressing CD25+CD4+ regulatory T cells. Am J Transplant. 2008; 8:1639-1651. [PubMed: 18557727]

55. Horn T, Christoffersen P, Henriksen JH. Alcoholic liver injury: defenestration in noncirrhotic livers--a scanning electron microscopic study. Hepatology. 1987; 7:77-82. [PubMed: 3542781]

56. Braet F, Wisse E. Structural and functional aspects of liver sinusoidal endothelial cell fenestrae: a review. Comp Hepatol. 2002; 1:1. [PubMed: 12437787]

57. Le Couteur DG, Fraser R, Hilmer S, Rivory LP, McLean AJ. The hepatic sinusoid in aging and cirrhosis: effects on hepatic substrate disposition and drug clearance. Clin Pharmacokinet. 2005; 44:187-200. [PubMed: 15656697]

58. Esser S, Wolburg K, Wolburg H, Breier G, Kurzchalia T, Risau W. Vascular endothelial growth factor induces endothelial fenestrations in vitro. J Cell Biol. 1998; 140:947-959. [PubMed: 9472045]

59. Fraser JR, Alcorn D, Laurent TC, Robinson AD, Ryan GB. Uptake of circulating hyaluronic acid by the rat liver. Cellular localization in situ. Cell Tissue Res. 1985; 242:505-510. [PubMed: 4075374]

60. Lohse AW, Knolle PA, Bilo K, Uhrig A, Waldmann C, Ibe M, Schmitt E, Gerken G, Meyer Zum Buschenfelde KH. Antigen-presenting function and B7 expression of murine sinusoidal endothelial cells and Kupffer cells. Gastroenterology. 1996; 110:1175-1181. [PubMed: 8613007]

61. Knolle PA, Gerken G, Loser E, Dienes HP, Gantner F, Tiegs G, Meyer zum Buschenfelde KH, Lohse AW. Role of sinusoidal endothelial cells of the liver in concanavalin A-induced hepatic injury in mice. Hepatology. 1996; 24:824-829. [PubMed: 8855184]

62. Knolle PA, Germann T, Treichel U, Uhrig A, Schmitt E, Hegenbarth S, Lohse AW, Gerken G. Endotoxin down-regulates $\mathrm{T}$ cell activation by antigen-presenting liver sinusoidal endothelial cells. J Immunol. 1999; 162:1401-1407. [PubMed: 9973395]

63. Knolle PA, Schmitt E, Jin S, Germann T, Duchmann R, Hegenbarth S, Gerken G, Lohse AW. Induction of cytokine production in naive CD4(+) T cells by antigen-presenting murine liver sinusoidal endothelial cells but failure to induce differentiation toward Th1 cells. Gastroenterology. 1999; 116:1428-1440. [PubMed: 10348827]

64. Knolle PA, Uhrig A, Hegenbarth S, Loser E, Schmitt E, Gerken G, Lohse AW. IL-10 downregulates $\mathrm{T}$ cell activation by antigen-presenting liver sinusoidal endothelial cells through decreased antigen uptake via the mannose receptor and lowered surface expression of accessory molecules. Clin Exp Immunol. 1998; 114:427-433. [PubMed: 9844054]

65. Limmer A, Ohl J, Kurts C, Ljunggren HG, Reiss Y, Groettrup M, Momburg F, Arnold B, Knolle PA. Efficient presentation of exogenous antigen by liver endothelial cells to CD8+ T cells results in antigen-specific T-cell tolerance. Nat Med. 2000; 6:1348-1354. [PubMed: 11100119]

66. Limmer A, Ohl J, Wingender G, Berg M, Jungerkes F, Schumak B, Djandji D, Scholz K, Klevenz A, Hegenbarth S, Momburg F, Hammerling GJ, Arnold B, Knolle PA. Cross-presentation of oral antigens by liver sinusoidal endothelial cells leads to CD8 T cell tolerance. Eur J Immunol. 2005; 35:2970-2981. [PubMed: 16163670]

67. Katz SC, Pillarisetty VG, Bleier JI, Shah AB, DeMatteo RP. Liver sinusoidal endothelial cells are insufficient to activate T cells. J Immunol. 2004; 173:230-235. [PubMed: 15210779] 
68. Berg M, Wingender G, Djandji D, Hegenbarth S, Momburg F, Hammerling G, Limmer A, Knolle P. Cross-presentation of antigens from apoptotic tumor cells by liver sinusoidal endothelial cells leads to tumor-specific CD8+ T cell tolerance. Eur J Immunol. 2006; 36:2960-2970. [PubMed: 17039564]

69. Elvevold KH, Nedredal GI, Revhaug A, Smedsrod B. Scavenger properties of cultivated pig liver endothelial cells. Comp Hepatol. 2004; 3:4. [PubMed: 15306034]

70. Onoe T, Ohdan H, Tokita D, Shishida M, Tanaka Y, Hara H, Zhou W, Ishiyama K, Mitsuta H, Ide $\mathrm{K}$, Asahara T. Liver sinusoidal endothelial cells tolerize T cells across MHC barriers in mice. $\mathrm{J}$ Immunol. 2005; 175:139-146. [PubMed: 15972640]

71. Diehl L, Schurich A, Grochtmann R, Hegenbarth S, Chen L, Knolle PA. Tolerogenic maturation of liver sinusoidal endothelial cells promotes B7-homolog 1-dependent CD8+ T cell tolerance. Hepatology. 2008; 47:296-305. [PubMed: 17975811]

72. Schildberg FA, Hegenbarth SI, Schumak B, Scholz K, Limmer A, Knolle PA. Liver sinusoidal endothelial cells veto CD8 T cell activation by antigen-presenting dendritic cells. Eur J Immunol. 2008; 38:957-967. [PubMed: 18383043]

73. Knolle P, Schlaak J, Uhrig A, Kempf P, Meyer zum Buschenfelde KH, Gerken G. Human Kupffer cells secrete IL-10 in response to lipopolysaccharide (LPS) challenge. J Hepatol. 1995; 22:226229. [PubMed: 7790711]

74. Connolly MK, Bedrosian AS, Malhotra A, Henning JR, Ibrahim J, Vera V, Cieza-Rubio NE, Hassan BU, Pachter HL, Cohen S, Frey AB, Miller G. In hepatic fibrosis, liver sinusoidal endothelial cells acquire enhanced immunogenicity. J Immunol. 2010; 185:2200-2208. [PubMed: 20639479]

75. Ge X, Karrar A, Ericzon BG, Broome U, Sumitran-Holgersson S. Antibodies to liver sinusoidal endothelial cells modulate immune responses in liver transplantation. Transplant Proc. 2005; 37:3335-3337. [PubMed: 16298589]

76. Sumitran-Holgersson S, Ge X, Karrar A, Xu B, Nava S, Broome U, Nowak G, Ericzon BG. A novel mechanism of liver allograft rejection facilitated by antibodies to liver sinusoidal endothelial cells. Hepatology. 2004; 40:1211-1221. [PubMed: 15486937]

77. Ju C, Pohl LR. Tolerogenic role of Kupffer cells in immune-mediated adverse drug reactions. Toxicology. 2005; 209:109-112. [PubMed: 15767021]

78. Ju C, McCoy JP, Chung CJ, Graf ML, Pohl LR. Tolerogenic role of Kupffer cells in allergic reactions. Chem Res Toxicol. 2003; 16:1514-1519. [PubMed: 14680364]

79. Sato K, Yabuki K, Haba T, Maekawa T. Role of Kupffer cells in the induction of tolerance after liver transplantation. J Surg Res. 1996; 63:433-438. [PubMed: 8661238]

80. Kamei T, Callery MP, Flye MW. Kupffer cell blockade prevents induction of portal venous tolerance in rat cardiac allograft transplantation. J Surg Res. 1990; 48:393-396. [PubMed: 2352416]

81. Callery MP, Kamei T, Flye MW. Kupffer cell blockade inhibits induction of tolerance by the portal venous route. Transplantation. 1989; 47:1092-1094. [PubMed: 2734830]

82. You Q, Cheng L, Kedl RM, Ju C. Mechanism of T cell tolerance induction by murine hepatic Kupffer cells. Hepatology. 2008; 48:978-990. [PubMed: 18712788]

83. Breous E, Somanathan S, Vandenberghe LH, Wilson JM. Hepatic regulatory T cells and Kupffer cells are crucial mediators of systemic $\mathrm{T}$ cell tolerance to antigens targeting murine liver. Hepatology. 2009; 50:612-621. [PubMed: 19575456]

84. Erhardt A, Biburger M, Papadopoulos T, Tiegs G. IL-10, regulatory T cells, and Kupffer cells mediate tolerance in concanavalin A-induced liver injury in mice. Hepatology. 2007; 45:475-485. [PubMed: 17256743]

85. Prickett TC, McKenzie JL, Hart DN. Characterization of interstitial dendritic cells in human liver. Transplantation. 1988; 46:754-761. [PubMed: 3057697]

86. Woo J, Lu L, Rao AS, Li Y, Subbotin V, Starzl TE, Thomson AW. Isolation, phenotype, and allostimulatory activity of mouse liver dendritic cells. Transplantation. 1994; 58:484-491. [PubMed: 8073517] 
87. Lian ZX, Okada T, He XS, Kita H, Liu YJ, Ansari AA, Kikuchi K, Ikehara S, Gershwin ME. Heterogeneity of dendritic cells in the mouse liver: identification and characterization of four distinct populations. J Immunol. 2003; 170:2323-2330. [PubMed: 12594254]

88. Chen L, Calomeni E, Wen J, Ozato K, Shen R, Gao JX. Natural killer dendritic cells are an intermediate of developing dendritic cells. J Leukoc Biol. 2007; 81:1422-1433. [PubMed: 17332372]

89. Pillarisetty VG, Shah AB, Miller G, Bleier JI, DeMatteo RP. Liver dendritic cells are less immunogenic than spleen dendritic cells because of differences in subtype composition. $\mathrm{J}$ Immunol. 2004; 172:1009-1017. [PubMed: 14707074]

90. O'Connell PJ, Morelli AE, Logar AJ, Thomson AW. Phenotypic and functional characterization of mouse hepatic CD8 alpha+ lymphoid-related dendritic cells. J Immunol. 2000; 165:795-803. [PubMed: 10878353]

91. Jomantaite I, Dikopoulos N, Kroger A, Leithauser F, Hauser H, Schirmbeck R, Reimann J. Hepatic dendritic cell subsets in the mouse. Eur J Immunol. 2004; 34:355-365. [PubMed: 14768040]

92. Hsu W, Shu SA, Gershwin E, Lian ZX. The current immune function of hepatic dendritic cells. Cell Mol Immunol. 2007; 4:321-328. [PubMed: 17976311]

93. Steptoe RJ, Patel RK, Subbotin VM, Thomson AW. Comparative analysis of dendritic cell density and total number in commonly transplanted organs: morphometric estimation in normal mice. Transpl Immunol. 2000; 8:49-56. [PubMed: 10834610]

94. Inatsu A, Kinoshita M, Nakashima H, Shimizu J, Saitoh D, Tamai S, Seki S. Novel mechanism of C-reactive protein for enhancing mouse liver innate immunity. Hepatology. 2009; 49:2044-2054. [PubMed: 19444871]

95. Khanna A, Morelli AE, Zhong C, Takayama T, Lu L, Thomson AW. Effects of liver-derived dendritic cell progenitors on Th1- and Th2-like cytokine responses in vitro and in vivo. $\mathrm{J}$ Immunol. 2000; 164:1346-1354. [PubMed: 10640749]

96. Buelens C, Verhasselt V, De Groote D, Thielemans K, Goldman M, Willems F. Human dendritic cell responses to lipopolysaccharide and CD40 ligation are differentially regulated by interleukin-10. Eur J Immunol. 1997; 27:1848-1852. [PubMed: 9295017]

97. Probst HC, McCoy K, Okazaki T, Honjo T, van den Broek M. Resting dendritic cells induce peripheral CD8+ T cell tolerance through PD-1 and CTLA-4. Nat Immunol. 2005; 6:280-286. [PubMed: 15685176]

98. Probst HC, Lagnel J, Kollias G, van den Broek M. Inducible transgenic mice reveal resting dendritic cells as potent inducers of CD8+ T cell tolerance. Immunity. 2003; 18:713-720. [PubMed: 12753747]

99. Matsuno K, Ezaki T, Kudo S, Uehara Y. A life stage of particle-laden rat dendritic cells in vivo: their terminal division, active phagocytosis, and translocation from the liver to the draining lymph. J Exp Med. 1996; 183:1865-1878. [PubMed: 8666943]

100. Kudo S, Matsuno K, Ezaki T, Ogawa M. A novel migration pathway for rat dendritic cells from the blood: hepatic sinusoids-lymph translocation. J Exp Med. 1997; 185:777-784. [PubMed: 9034155]

101. Vinas O, Bataller R, Sancho-Bru P, Gines P, Berenguer C, Enrich C, Nicolas JM, Ercilla G, Gallart T, Vives J, Arroyo V, Rodes J. Human hepatic stellate cells show features of antigenpresenting cells and stimulate lymphocyte proliferation. Hepatology. 2003; 38:919-929. [PubMed: 14512879]

102. Schwabe RF, Schnabl B, Kweon YO, Brenner DA. CD40 activates NF-kappa B and c-Jun Nterminal kinase and enhances chemokine secretion on activated human hepatic stellate cells. J Immunol. 2001; 166:6812-6819. [PubMed: 11359840]

103. Winau F, Hegasy G, Weiskirchen R, Weber S, Cassan C, Sieling PA, Modlin RL, Liblau RS, Gressner AM, Kaufmann SH. Ito cells are liver-resident antigen-presenting cells for activating T cell responses. Immunity. 2007; 26:117-129. [PubMed: 17239632]

104. Chen CH, Kuo LM, Chang Y, Wu W, Goldbach C, Ross MA, Stolz DB, Chen L, Fung JJ, Lu L, Qian S. In vivo immune modulatory activity of hepatic stellate cells in mice. Hepatology. 2006; 44:1171-1181. [PubMed: 17058227] 
105. Benten D, Kumaran V, Joseph B, Schattenberg J, Popov Y, Schuppan D, Gupta S. Hepatocyte transplantation activates hepatic stellate cells with beneficial modulation of cell engraftment in the rat. Hepatology. 2005; 42:1072-1081. [PubMed: 16250034]

106. Yu MC, Chen CH, Liang X, Wang L, Gandhi CR, Fung JJ, Lu L, Qian S. Inhibition of T-cell responses by hepatic stellate cells via B7-H1-mediated T-cell apoptosis in mice. Hepatology. 2004; 40:1312-1321. [PubMed: 15565659]

107. Warren A, Le Couteur DG, Fraser R, Bowen DG, McCaughan GW, Bertolino P. T lymphocytes interact with hepatocytes through fenestrations in murine liver sinusoidal endothelial cells. Hepatology. 2006; 44:1182-1190. [PubMed: 17058232]

108. Schroder AJ, Blaheta RA, Scholz M, Kronenberger B, Encke A, Markus BH. Effects of proinflammatory cytokines on cultivated primary human hepatocytes. Fluorometric measurement of intercellular adhesion molecule-1 and human leukocyte antigen-A, -B, -C, and -DR expression. Transplantation. 1995; 59:1023-1028. [PubMed: 7709438]

109. Bertolino P, Trescol-Biemont MC, Rabourdin-Combe C. Hepatocytes induce functional activation of naive CD8+ T lymphocytes but fail to promote survival. Eur J Immunol. 1998; 28:221-236. [PubMed: 9485202]

110. Holz LE, Benseler V, Bowen DG, Bouillet P, Strasser A, O'Reilly L, d'Avigdor WM, Bishop AG, McCaughan GW, Bertolino P. Intrahepatic murine CD8 T-cell activation associates with a distinct phenotype leading to Bim-dependent death. Gastroenterology. 2008; 135:989-997. [PubMed: 18619445]

111. Bowen DG, Zen M, Holz L, Davis T, McCaughan GW, Bertolino P. The site of primary T cell activation is a determinant of the balance between intrahepatic tolerance and immunity. J Clin Invest. 2004; 114:701-712. [PubMed: 15343389]

112. Qian S, Wang Z, Lee Y, Chiang Y, Bonham C, Fung J, Lu L. Hepatocyte-induced apoptosis of activated $\mathrm{T}$ cells, a mechanism of liver transplant tolerance, is related to the expression of ICAM-1 and hepatic lectin. Transplant Proc. 2001; 33:226. [PubMed: 11266790]

113. Arnold B. Parenchymal cells in immune and tolerance induction. Immunol Lett. 2003; 89:225228. [PubMed: 14556982]

114. Schonrich G, Momburg F, Malissen M, Schmitt-Verhulst AM, Malissen B, Hammerling GJ, Arnold B. Distinct mechanisms of extrathymic T cell tolerance due to differential expression of self antigen. Int Immunol. 1992; 4:581-590. [PubMed: 1627495]

115. Scholz M, Cinatl J, Blaheta RA, Kornhuber B, Markus BH, Doerr HW. Expression of human leukocyte antigens class I and class II on cultured biliary epithelial cells after cytomegalovirus infection. Tissue Antigens. 1997; 49:640-643. [PubMed: 9234487]

116. Tsuneyama K, Harada K, Yasoshima M, Kaji K, Gershwin ME, Nakanuma Y. Expression of costimulatory factor B7-2 on the intrahepatic bile ducts in primary biliary cirrhosis and primary sclerosing cholangitis: an immunohistochemical study. J Pathol. 1998; 186:126-130. [PubMed: 9924426]

117. Leon MP, Bassendine MF, Gibbs P, Burt AD, Thick M, Kirby JA. Hepatic allograft rejection: regulation of the immunogenicity of human intrahepatic biliary epithelial cells. Liver Transpl Surg. 1996; 2:37-45. [PubMed: 9346626]

118. Leon MP, Bassendine MF, Gibbs P, Thick M, Kirby JA. Immunogenicity of biliary epithelium: study of the adhesive interaction with lymphocytes. Gastroenterology. 1997; 112:968-977. [PubMed: 9041260]

119. Leon MP, Bassendine MF, Wilson JL, Ali S, Thick M, Kirby JA. Immunogenicity of biliary epithelium: investigation of antigen presentation to CD4+ T cells. Hepatology. 1996; 24:561567. [PubMed: 8781325]

120. Leon MP, Kirby JA, Gibbs P, Burt AD, Bassendine MF. Immunogenicity of biliary epithelial cells: study of the expression of B7 molecules. J Hepatol. 1995; 22:591-595. [PubMed: 7544369]

121. Dillon PW, Belchis D, Minnick K, Tracy T. Differential expression of the major histocompatibility antigens and ICAM-1 on bile duct epithelial cells in biliary atresia. Tohoku J Exp Med. 1997; 181:33-40. [PubMed: 9149337]

122. Kaplan MM, Gershwin ME. Primary biliary cirrhosis. The New England journal of medicine. 2005; 353:1261-1273. [PubMed: 16177252] 
123. Gershwin ME, Mackay IR. The causes of primary biliary cirrhosis: Convenient and inconvenient truths. Hepatology. 2008; 47:737-745. [PubMed: 18098322]

124. Hirschfield GM, Liu X, Han Y, Gorlov IP, Lu Y, Xu C, Chen W, Juran BD, Coltescu C, Mason AL, Milkiewicz P, Myers RP, Odin JA, Luketic VA, Speiciene D, Vincent C, Levy C, Gregersen PK, Zhang J, Heathcote EJ, Lazaridis KN, Amos CI, Siminovitch KA. Variants at IRF5-TNPO3, 17q12-21 and MMEL1 are associated with primary biliary cirrhosis. Nat Genet. 2010; 42:655657. [PubMed: 20639879]

125. Hirschfield GM, Liu X, Xu C, Lu Y, Xie G, Gu X, Walker EJ, Jing K, Juran BD, Mason AL, Myers RP, Peltekian KM, Ghent CN, Coltescu C, Atkinson EJ, Heathcote EJ, Lazaridis KN, Amos CI, Siminovitch KA. Primary biliary cirrhosis associated with HLA, IL12A, and IL12RB2 variants. The New England journal of medicine. 2009; 360:2544-2555. [PubMed: 19458352]

126. Invernizzi P. Human leukocyte antigen in primary biliary cirrhosis: an old story now reviving. Hepatology. 2011; 54:714-723. [PubMed: 21563204]

127. Liu X, Invernizzi P, Lu Y, Kosoy R, Bianchi I, Podda M, Xu C, Xie G, Macciardi F, Selmi C, Lupoli S, Shigeta R, Ransom M, Lleo A, Lee AT, Mason AL, Myers RP, Peltekian KM, Ghent CN, Bernuzzi F, Zuin M, Rosina F, Borghesio E, Floreani A, Lazzari R, Niro G, Andriulli A, Muratori L, Muratori P, Almasio PL, Andreone P, Margotti M, Brunetto M, Coco B, Alvaro D, Bragazzi MC, Marra F, Pisano A, Rigamonti C, Colombo M, Marzioni M, Benedetti A, Fabris L, Strazzabosco M, Portincasa P, Palmieri VO, Tiribelli C, Croce L, Bruno S, Rossi S, Vinci M, Prisco C, Mattalia A, Toniutto P, Picciotto A, Galli A, Ferrari C, Colombo S, Casella G, Morini L, Caporaso N, Colli A, Spinzi G, Montanari R, Gregersen PK, Heathcote EJ, Hirschfield GM, Siminovitch KA, Amos CI, Gershwin ME, Seldin MF. Genome-wide meta-analyses identify three loci associated with primary biliary cirrhosis. Nat Genet. 2010; 42:658-660. [PubMed: 20639880]

128. Mells GF, Floyd JA, Morley KI, Cordell HJ, Franklin CS, Shin SY, Heneghan MA, Neuberger JM, Donaldson PT, Day DB, Ducker SJ, Muriithi AW, Wheater EF, Hammond CJ, Dawwas MF, Jones DE, Peltonen L, Alexander GJ, Sandford RN, Anderson CA. Genome-wide association study identifies 12 new susceptibility loci for primary biliary cirrhosis. Nat Genet. 2011; 43:329332. [PubMed: 21399635]

129. Liberal R, Longhi MS, Mieli-Vergani G, Vergani D. Pathogenesis of autoimmune hepatitis. Best Pract Res Clin Gastroenterol. 2011; 25:653-664. [PubMed: 22117632]

130. Vergani D, Longhi MS, Bogdanos DP, Ma Y, Mieli-Vergani G. Autoimmune hepatitis. Semin Immunopathol. 2009; 31:421-435. [PubMed: 19533129]

131. Vergani D, Choudhuri K, Bogdanos DP, Mieli-Vergani G. Pathogenesis of autoimmune hepatitis. Clin Liver Dis. 2002; 6:727-737. [PubMed: 12362577]

132. Wei HX, Chuang YH, Li B, Wei H, Sun R, Moritoki Y, Gershwin ME, Lian ZX, Tian Z. CD4+ $\mathrm{CD} 25+$ Foxp3 + regulatory $\mathrm{T}$ cells protect against $\mathrm{T}$ cell-mediated fulminant hepatitis in a TGFbeta-dependent manner in mice. J Immunol. 2008; 181:7221-7229. [PubMed: 18981144]

133. Oertelt S, Lian ZX, Cheng CM, Chuang YH, Padgett KA, He XS, Ridgway WM, Ansari AA, Coppel RL, Li MO, Flavell RA, Kronenberg M, Mackay IR, Gershwin ME. Anti-mitochondrial antibodies and primary biliary cirrhosis in TGF-beta receptor II dominant-negative mice. J Immunol. 2006; 177:1655-1660. [PubMed: 16849474]

134. Aoki CA, Borchers AT, Li M, Flavell RA, Bowlus CL, Ansari AA, Gershwin ME. Transforming growth factor beta (TGF-beta) and autoimmunity. Autoimmun Rev. 2005; 4:450-459. [PubMed: 16137611]

135. Wakabayashi K, Yoshida K, Leung PS, Moritoki Y, Yang GX, Tsuneyama K, Lian ZX, Hibi T, Ansari AA, Wicker LS, Ridgway WM, Coppel RL, Mackay IR, Gershwin ME. Induction of autoimmune cholangitis in non-obese diabetic (NOD).1101 mice following a chemical xenobiotic immunization. Clin Exp Immunol. 2009; 155:577-586. [PubMed: 19094117]

136. Wakabayashi K, Lian ZX, Leung PS, Moritoki Y, Tsuneyama K, Kurth MJ, Lam KS, Yoshida K, Yang GX, Hibi T, Ansari AA, Ridgway WM, Coppel RL, Mackay IR, Gershwin ME. Loss of tolerance in $\mathrm{C} 57 \mathrm{BL} / 6$ mice to the autoantigen $\mathrm{E} 2$ subunit of pyruvate dehydrogenase by a xenobiotic with ensuing biliary ductular disease. Hepatology. 2008; 48:531-540. [PubMed: 18563844] 
137. Leung PS, Park O, Tsuneyama K, Kurth MJ, Lam KS, Ansari AA, Coppel RL, Gershwin ME. Induction of primary biliary cirrhosis in guinea pigs following chemical xenobiotic immunization. J Immunol. 2007; 179:2651-2657. [PubMed: 17675529]

138. Kimura Y, Selmi C, Leung PS, Mao TK, Schauer J, Watnik M, Kuriyama S, Nishioka M, Ansari AA, Coppel RL, Invernizzi P, Podda M, Gershwin ME. Genetic polymorphisms influencing xenobiotic metabolism and transport in patients with primary biliary cirrhosis. Hepatology. 2005; 41:55-63. [PubMed: 15690482]

139. Amano K, Leung PS, Xu Q, Marik J, Quan C, Kurth MJ, Nantz MH, Ansari AA, Lam KS, Zeniya M, Coppel RL, Gershwin ME. Xenobiotic-induced loss of tolerance in rabbits to the mitochondrial autoantigen of primary biliary cirrhosis is reversible. J Immunol. 2004; 172:64446452. [PubMed: 15128836]

140. Selmi C, Balkwill DL, Invernizzi P, Ansari AA, Coppel RL, Podda M, Leung PS, Kenny TP, Van De Water J, Nantz MH, Kurth MJ, Gershwin ME. Patients with primary biliary cirrhosis react against a ubiquitous xenobiotic-metabolizing bacterium. Hepatology. 2003; 38:1250-1257. [PubMed: 14578864]

141. Leung PS, Quan C, Park O, Van de Water J, Kurth MJ, Nantz MH, Ansari AA, Coppel RL, Lam KS, Gershwin ME. Immunization with a xenobiotic 6-bromohexanoate bovine serum albumin conjugate induces antimitochondrial antibodies. J Immunol. 2003; 170:5326-5332. [PubMed: 12734383]

142. He XS, Ansari AA, Gershwin ME. Xenobiotic considerations for the development of autoimmune liver diseases: bad genes and bad luck. Rev Environ Health. 2001; 16:191-202. [PubMed: 11765908]

143. Amano K, Leung PS, Rieger R, Quan C, Wang X, Marik J, Suen YF, Kurth MJ, Nantz MH, Ansari AA, Lam KS, Zeniya M, Matsuura E, Coppel RL, Gershwin ME. Chemical xenobiotics and mitochondrial autoantigens in primary biliary cirrhosis: identification of antibodies against a common environmental, cosmetic, and food additive, 2-octynoic acid. J Immunol. 2005; 174:5874-5883. [PubMed: 15845458]

144. Park O, Grishina I, Leung PS, Gershwin ME, Prindiville T. Analysis of the Foxp3/scurfin gene in Crohn's disease. Ann N Y Acad Sci. 2005; 1051:218-228. [PubMed: 16126962]

145. Mackay I. Primary biliary cirrhosis showing a high titre of autoantibody: report of a case of a study. N Engl J Med. 1958:185-188. [PubMed: 13493762]

146. Asherson GR. Antibodies against nuclear and cytoplasmic cell constituents in systemic lupus erythematosus and other liver diseases. Br J Exp Pathol. 1959; 40:209-213. [PubMed: 13662525]

147. Doniach D, Roitt I, Walker J, Sherlock S. Tissue antibodies in primary biliary cirrhosis, active chronic (lupoid) hepatitis, cryptogenic cirrhosis and other diseases and their clinical implications. Clin Exp Immunol. 1966; 1:237-262. [PubMed: 5330183]

148. Berg PA, Doniach D, Roitt IM. Mitochondrial antibodies in primary biliary cirrhosis. I. Localization of the antigen to mitochondrial membranes. J Exp Med. 1967; 126:277-290. [PubMed: 4165742]

149. Gershwin ME, Mackay IR, Sturgess A, Coppel RL. Identification and specificity of a cDNA encoding the $70 \mathrm{kd}$ mitochondrial antigen recognized in primary biliary cirrhosis. J Immunol. 1987; 138:3525-3531. [PubMed: 3571977]

150. Van de Water J, Gershwin ME, Leung P, Ansari A, Coppel RL. The autoepitope of the 74-kD mitochondrial autoantigen of primary biliary cirrhosis corresponds to the functional site of dihydrolipoamide acetyltransferase. J Exp Med. 1988; 167:1791-1799. [PubMed: 2455013]

151. Yeaman SJ, Fussey SP, Danner DJ, James OF, Mutimer DJ, Bassendine MF. Primary biliary cirrhosis: identification of two major M2 mitochondrial autoantigens. Lancet. 1988; 1:10671070. [PubMed: 2896910]

152. Fussey SP, Guest JR, James OF, Bassendine MF, Yeaman SJ. Identification and analysis of the major M2 autoantigens in primary biliary cirrhosis. Proc Natl Acad Sci U S A. 1988; 85:86548658. [PubMed: 3186751]

153. Fussey SP, Bassendine MF, James OF, Yeaman SJ. Characterisation of the reactivity of autoantibodies in primary biliary cirrhosis. FEBS Lett. 1989; 246:49-53. [PubMed: 2468528] 
154. Fussey SP, Bassendine MF, Fittes D, Turner IB, James OF, Yeaman SJ. The E1 alpha and beta subunits of the pyruvate dehydrogenase complex are M2'd' and M2'e' autoantigens in primary biliary cirrhosis. Clin Sci (Lond). 1989; 77:365-368. [PubMed: 2805598]

155. De Marcucci O, Lindsay JG. Component X. An immunologically distinct polypeptide associated with mammalian pyruvate dehydrogenase multi-enzyme complex. Eur J Biochem. 1985; 149:641-648. [PubMed: 4006943]

156. Surh CD, Danner DJ, Ahmed A, Coppel RL, Mackay IR, Dickson ER, Gershwin ME. Reactivity of primary biliary cirrhosis sera with a human fetal liver cDNA clone of branched-chain alphaketo acid dehydrogenase dihydrolipoamide acyltransferase, the $52 \mathrm{kD}$ mitochondrial autoantigen. Hepatology. 1989; 9:63-68. [PubMed: 2908870]

157. Baum H. Nature of the mitochondrial antigens of primary biliary cirrhosis and their possible relationships to the etiology of the disease. Semin Liver Dis. 1989; 9:117-123. [PubMed: 2658103]

158. Baum H, Berg PA. The complex nature of mitochondrial antibodies and their relation to primary biliary cirrhosis. Semin Liver Dis. 1981; 1:309-321. [PubMed: 6180480]

159. Nishio A, Van de Water J, Leung PS, Joplin R, Neuberger JM, Lake J, Bjorkland A, Totterman TH, Peters M, Worman HJ, Ansari AA, Coppel RL, Gershwin ME. Comparative studies of antimitochondrial autoantibodies in sera and bile in primary biliary cirrhosis. Hepatology. 1997; 25:1085-1089. [PubMed: 9141421]

160. Tanaka A, Nalbandian G, Leung PS, Benson GD, Munoz S, Findor JA, Branch AD, Coppel RL, Ansari AA, Gershwin ME. Mucosal immunity and primary biliary cirrhosis: presence of antimitochondrial antibodies in urine. Hepatology. 2000; 32:910-915. [PubMed: 11050038]

161. Reynoso-Paz S, Leung PS, Van De Water J, Tanaka A, Munoz S, Bass N, Lindor K, Donald PJ, Coppel RL, Ansari AA, Gershwin ME. Evidence for a locally driven mucosal response and the presence of mitochondrial antigens in saliva in primary biliary cirrhosis. Hepatology. 2000; 31:24-29. [PubMed: 10613723]

162. Van de Water J, Fregeau D, Davis P, Ansari A, Danner D, Leung P, Coppel R, Gershwin ME. Autoantibodies of primary biliary cirrhosis recognize dihydrolipoamide acetyltransferase and inhibit enzyme function. J Immunol. 1988; 141:2321-2324. [PubMed: 3049806]

163. Leung PS, Chuang DT, Wynn RM, Cha S, Danner DJ, Ansari A, Coppel RL, Gershwin ME. Autoantibodies to BCOADC-E2 in patients with primary biliary cirrhosis recognize a conformational epitope. Hepatology. 1995; 22:505-513. [PubMed: 7543435]

164. Dubel L, Tanaka A, Leung PS, Van de Water J, Coppel R, Roche T, Johanet C, Motokawa Y, Ansari A, Gershwin ME. Autoepitope mapping and reactivity of autoantibodies to the dihydrolipoamide dehydrogenase-binding protein (E3BP) and the glycine cleavage proteins in primary biliary cirrhosis. Hepatology. 1999; 29:1013-1018. [PubMed: 10094940]

165. Fregeau DR, Davis PA, Danner DJ, Ansari A, Coppel RL, Dickson ER, Gershwin ME. Antimitochondrial antibodies of primary biliary cirrhosis recognize dihydrolipoamide acyltransferase and inhibit enzyme function of the branched chain alpha-ketoacid dehydrogenase complex. J Immunol. 1989; 142:3815-3820. [PubMed: 2715637]

166. Fregeau DR, Leung PS, Coppel RL, McNeilage LJ, Medsger TA Jr, Gershwin ME. Autoantibodies to mitochondria in systemic sclerosis. Frequency and characterization using recombinant cloned autoantigen. Arthritis Rheum. 1988; 31:386-392. [PubMed: 3282519]

167. Fregeau DR, Prindiville T, Coppel RL, Kaplan M, Dickson ER, Gershwin ME. Inhibition of alpha-ketoglutarate dehydrogenase activity by a distinct population of autoantibodies recognizing dihydrolipoamide succinyltransferase in primary biliary cirrhosis. Hepatology. 1990; 11:975981. [PubMed: 2365294]

168. Fregeau DR, Roche TE, Davis PA, Coppel R, Gershwin ME. Primary biliary cirrhosis. Inhibition of pyruvate dehydrogenase complex activity by autoantibodies specific for E1 alpha, a non-lipoic acid containing mitochondrial enzyme. J Immunol. 1990; 144:1671-1676. [PubMed: 2106552]

169. Surh CD, Roche TE, Danner DJ, Ansari A, Coppel RL, Prindiville T, Dickson ER, Gershwin ME. Antimitochondrial autoantibodies in primary biliary cirrhosis recognize cross-reactive epitope(s) on protein $\mathrm{X}$ and dihydrolipoamide acetyltransferase of pyruvate dehydrogenase complex. Hepatology. 1989; 10:127-133. [PubMed: 2473022] 
170. Surh CD, Coppel R, Gershwin ME. Structural requirement for autoreactivity on human pyruvate dehydrogenase-E2, the major autoantigen of primary biliary cirrhosis. Implication for a conformational autoepitope. J Immunol. 1990; 144:3367-3374. [PubMed: 1691756]

171. Mackay IR, Whittingham S, Fida S, Myers M, Ikuno N, Gershwin ME, Rowley MJ. The peculiar autoimmunity of primary biliary cirrhosis. Immunol Rev. 2000; 174:226-237. [PubMed: 10807519]

172. Van de Water J, Ansari A, Prindiville T, Coppel RL, Ricalton N, Kotzin BL, Liu S, Roche TE, Krams SM, Munoz S, et al. Heterogeneity of autoreactive T cell clones specific for the E2 component of the pyruvate dehydrogenase complex in primary biliary cirrhosis. J Exp Med. 1995; 181:723-733. [PubMed: 7836925]

173. Van de Water J, Ansari AA, Surh CD, Coppel R, Roche T, Bonkovsky H, Kaplan M, Gershwin ME. Evidence for the targeting by 2-oxo-dehydrogenase enzymes in the T cell response of primary biliary cirrhosis. J Immunol. 1991; 146:89-94. [PubMed: 1984455]

174. Shimoda S, Nakamura M, Ishibashi H, Hayashida K, Niho Y. HLA DRB4 0101-restricted immunodominant $\mathrm{T}$ cell autoepitope of pyruvate dehydrogenase complex in primary biliary cirrhosis: evidence of molecular mimicry in human autoimmune diseases. J Exp Med. 1995; 181:1835-1845. [PubMed: 7536796]

175. Shimoda S, Nakamura M, Shigematsu H, Tanimoto H, Gushima T, Gershwin ME, Ishibashi H. Mimicry peptides of human PDC-E2 163-176 peptide, the immunodominant T-cell epitope of primary biliary cirrhosis. Hepatology. 2000; 31:1212-1216. [PubMed: 10827144]

176. Shimoda S, Van de Water J, Ansari A, Nakamura M, Ishibashi H, Coppel RL, Lake J, Keeffe EB, Roche TE, Gershwin ME. Identification and precursor frequency analysis of a common T cell epitope motif in mitochondrial autoantigens in primary biliary cirrhosis. J Clin Invest. 1998; 102:1831-1840. [PubMed: 9819369]

177. Kita H, Lian ZX, Van de Water J, He XS, Matsumura S, Kaplan M, Luketic V, Coppel RL, Ansari AA, Gershwin ME. Identification of HLA-A2-restricted CD8(+) cytotoxic T cell responses in primary biliary cirrhosis: $\mathrm{T}$ cell activation is augmented by immune complexes cross-presented by dendritic cells. J Exp Med. 2002; 195:113-123. [PubMed: 11781370]

178. Kita H, Matsumura S, He XS, Ansari AA, Lian ZX, Van de Water J, Coppel RL, Kaplan MM, Gershwin ME. Quantitative and functional analysis of PDC-E2-specific autoreactive cytotoxic T lymphocytes in primary biliary cirrhosis. J Clin Invest. 2002; 109:1231-1240. [PubMed: 11994412]

179. Bogdanos DP, Baum H, Grasso A, Okamoto M, Butler P, Ma Y, Rigopoulou E, Montalto P, Davies ET, Burroughs AK, Vergani D. Microbial mimics are major targets of crossreactivity with human pyruvate dehydrogenase in primary biliary cirrhosis. J Hepatol. 2004; 40:31-39. [PubMed: 14672611]

180. Bogdanos DP, Baum H, Okamoto M, Montalto P, Sharma UC, Rigopoulou EI, Vlachogiannakos J, Ma Y, Burroughs AK, Vergani D. Primary biliary cirrhosis is characterized by IgG3 antibodies cross-reactive with the major mitochondrial autoepitope and its Lactobacillus mimic. Hepatology. 2005; 42:458-465. [PubMed: 16025495]

181. Lleo A, Bowlus CL, Yang GX, Invernizzi P, Podda M, Van de Water J, Ansari AA, Coppel RL, Worman HJ, Gores GJ, Gershwin ME. Biliary apotopes and anti-mitochondrial antibodies activate innate immune responses in primary biliary cirrhosis. Hepatology. 2010; 52:987-998. [PubMed: 20568301]

182. Lleo A, Selmi C, Invernizzi P, Podda M, Coppel RL, Mackay IR, Gores GJ, Ansari AA, Van de Water J, Gershwin ME. Apotopes and the biliary specificity of primary biliary cirrhosis. Hepatology. 2009; 49:871-879. [PubMed: 19185000]

183. Rong G, Zhong R, Lleo A, Leung PS, Bowlus CL, Yang GX, Yang CY, Coppel RL, Ansari AA, Cuebas DA, Worman HJ, Invernizzi P, Gores GJ, Norman G, He XS, Gershwin ME. Epithelial cell specificity and apotope recognition by serum autoantibodies in primary biliary cirrhosis. Hepatology. 2011; 54:196-203. [PubMed: 21488079]

184. Harada K, Shimoda S, Ikeda H, Chiba M, Hsu M, Sato Y, Kobayashi M, Ren XS, Ohta H, Kasashima S, Kawashima A, Nakanuma Y. Significance of periductal Langerhans cells and biliary epithelial cell-derived macrophage inflammatory protein-3alpha in the pathogenesis of primary biliary cirrhosis. Liver Int. 2011; 31:245-253. [PubMed: 21092071] 
185. Selmi C, Lleo A, Pasini S, Zuin M, Gershwin ME. Innate immunity and primary biliary cirrhosis. Curr Mol Med. 2009; 9:45-51. [PubMed: 19199941]

186. Shimoda S, Harada K, Niiro H, Shirabe K, Taketomi A, Maehara Y, Tsuneyama K, Nakanuma Y, Leung P, Ansari AA, Gershwin ME, Akashi K. Interaction between Toll-like receptors and natural killer cells in the destruction of bile ducts in primary biliary cirrhosis. Hepatology. 2011; 53:1270-1281. [PubMed: 21400555]

187. Ikeda H, Sasaki M, Ishikawa A, Sato Y, Harada K, Zen Y, Kazumori H, Nakanuma Y. Interaction of Toll-like receptors with bacterial components induces expression of CDX2 and MUC2 in rat biliary epithelium in vivo and in culture. Lab Invest. 2007; 87:559-571. [PubMed: 17417665]

188. Harada K, Ohira S, Isse K, Ozaki S, Zen Y, Sato Y, Nakanuma Y. Lipopolysaccharide activates nuclear factor-kappaB through toll-like receptors and related molecules in cultured biliary epithelial cells. Lab Invest. 2003; 83:1657-1667. [PubMed: 14615419]

189. Harada K, Shimoda S, Sato Y, Isse K, Ikeda H, Nakanuma Y. Periductal interleukin-17 production in association with biliary innate immunity contributes to the pathogenesis of cholangiopathy in primary biliary cirrhosis. Clin Exp Immunol. 2009; 157:261-270. [PubMed: 19604266]

190. Wakabayashi K, Lian ZX, Moritoki Y, Lan RY, Tsuneyama K, Chuang YH, Yang GX, Ridgway W, Ueno Y, Ansari AA, Coppel RL, Mackay IR, Gershwin ME. IL-2 receptor alpha(-/-) mice and the development of primary biliary cirrhosis. Hepatology. 2006; 44:1240-1249. [PubMed: 17058261]

191. Yang GX, Lian ZX, Chuang YH, Moritoki Y, Lan RY, Wakabayashi K, Ansari AA, Flavell RA, Ridgway WM, Coppel RL, Tsuneyama K, Mackay IR, Gershwin ME. Adoptive transfer of CD8(+) T cells from transforming growth factor beta receptor type II (dominant negative form) induces autoimmune cholangitis in mice. Hepatology. 2008; 47:1974-1982. [PubMed: 18452147]

192. Mackay IR, Taft LI, Cowling DC. Lupoid hepatitis. Lancet. 1956; 271:1323-1326. [PubMed: 13386250]

193. Johnson PJ, McFarlane IG. Meeting report: International Autoimmune Hepatitis Group. Hepatology. 1993; 18:998-1005. [PubMed: 8406375]

194. Alvarez F, Berg PA, Bianchi FB, Bianchi L, Burroughs AK, Cancado EL, Chapman RW, Cooksley WG, Czaja AJ, Desmet VJ, Donaldson PT, Eddleston AL, Fainboim L, Heathcote J, Homberg JC, Hoofnagle JH, Kakumu S, Krawitt EL, Mackay IR, MacSween RN, Maddrey WC, Manns MP, McFarlane IG, Meyer zum Buschenfelde KH, Zeniya M, et al. International Autoimmune Hepatitis Group Report: review of criteria for diagnosis of autoimmune hepatitis. J Hepatol. 1999; 31:929-938. [PubMed: 10580593]

195. Hennes EM, Zeniya M, Czaja AJ, Pares A, Dalekos GN, Krawitt EL, Bittencourt PL, Porta G, Boberg KM, Hofer H, Bianchi FB, Shibata M, Schramm C, Eisenmann de Torres B, Galle PR, McFarlane I, Dienes HP, Lohse AW. Simplified criteria for the diagnosis of autoimmune hepatitis. Hepatology. 2008; 48:169-176. [PubMed: 18537184]

196. Vergani D, Mieli-Vergani G, Mondelli M, Portmann B, Eddleston AL. Immunoglobulin on the surface of isolated hepatocytes is associated with antibody-dependent cell-mediated cytotoxicity and liver damage. Liver. 1987; 7:307-315. [PubMed: 3437792]

197. Wen L, Peakman M, Lobo-Yeo A, McFarlane BM, Mowat AP, Mieli-Vergani G, Vergani D. Tcell-directed hepatocyte damage in autoimmune chronic active hepatitis. Lancet. 1990; 336:1527-1530. [PubMed: 1979365]

198. Gabbiani G, Ryan GB, Lamelin JP, Vassalli P, Majno G, Bouvier CA, Cruchaud A, Luscher EF. Human smooth muscle autoantibody. Its identification as antiactin antibody and a study of its binding to "nonmuscular" cells. Am J Pathol. 1973; 72:473-488. [PubMed: 4125700]

199. Bottazzo GF, Florin-Christensen A, Fairfax A, Swana G, Doniach D, Groeschel-Stewart U. Classification of smooth muscle autoantibodies detected by immunofluorescence. J Clin Pathol. 1976; 29:403-410. [PubMed: 777046]

200. Czaja AJ, Morshed SA, Parveen S, Nishioka M. Antibodies to single-stranded and doublestranded DNA in antinuclear antibody-positive type 1-autoimmune hepatitis. Hepatology. 1997; 26:567-572. [PubMed: 9303484] 
201. Bogdanos DP, Invernizzi P, Mackay IR, Vergani D. Autoimmune liver serology: current diagnostic and clinical challenges. World J Gastroenterol. 2008; 14:3374-3387. [PubMed: 18528935]

202. Bogdanos DP, Mieli-Vergani G, Vergani D. Autoantibodies and their antigens in autoimmune hepatitis. Semin Liver Dis. 2009; 29:241-253. [PubMed: 19675997]

203. Berg PA, Stechemesser E, Strienz J. Hypergammaglobulinamische chronisch aktive Hepatitis mit Nachweis von leberpankreas-spezifischen komplementbindenden Autoantikorpern. Verh Dtsch Ges Inn Med. 1981; 87:921-927.

204. Gelpi C, Sontheimer EJ, Rodriguez-Sanchez JL. Autoantibodies against a serine tRNA-protein complex implicated in cotranslational selenocysteine insertion. Proc Natl Acad Sci U S A. 1992; 89:9739-9743. [PubMed: 1409691]

205. Lapierre P, Hajoui O, Homberg JC, Alvarez F. Formiminotransferase cyclodeaminase is an organ-specific autoantigen recognized by sera of patients with autoimmune hepatitis. Gastroenterology. 1999; 116:643-649. [PubMed: 10029623]

206. Wies I, Brunner S, Henninger J, Herkel J, Kanzler S, Meyer zum Buschenfelde KH, Lohse AW. Identification of target antigen for SLA/LP autoantibodies in autoimmune hepatitis. Lancet. 2000; 355:1510-1515. [PubMed: 10801173]

207. Gueguen M, Meunier-Rotival M, Bernard O, Alvarez F. Anti-liver kidney microsome antibody recognizes a cytochrome P450 from the IID subfamily. J Exp Med. 1988; 168:801-806. [PubMed: 2842431]

208. Bogdanos DP, Dalekos GN. Enzymes as target antigens of liver-specific autoimmunity: the case of cytochromes P450s. Curr Med Chem. 2008; 15:2285-2292. [PubMed: 18781950]

209. Clemente MG, Meloni A, Obermayer-Straub P, Frau F, Manns MP, De Virgiliis S. Two cytochromes $\mathrm{P} 450$ are major hepatocellular autoantigens in autoimmune polyglandular syndrome type 1. Gastroenterology. 1998; 114:324-328. [PubMed: 9453493]

210. Bogdanos DP, Muratori L, Bianchi FB, Vergani D. Hepatitis C virus and autoimmunity. Hepatology. 2000; 31:1380. [PubMed: 10866525]

211. Ma Y, Bogdanos DP, Hussain MJ, Underhill J, Bansal S, Longhi MS, Cheeseman P, MieliVergani G, Vergani D. Polyclonal T-cell responses to cytochrome P450IID6 are associated with disease activity in autoimmune hepatitis type 2. Gastroenterology. 2006; 130:868-882. [PubMed: 16530525]

212. Longhi MS, Hussain MJ, Bogdanos DP, Quaglia A, Mieli-Vergani G, Ma Y, Vergani D. Cytochrome P450IID6-specific CD8 T cell immune responses mirror disease activity in autoimmune hepatitis type 2. Hepatology. 2007; 46:472-484. [PubMed: 17559153]

213. Hodgson HJ, Wands JR, Isselbacher KJ. Alteration in suppressor cell activity in chronic active hepatitis. Proc Natl Acad Sci U S A. 1978; 75:1549-1553. [PubMed: 274739]

214. Vento S, Hegarty JE, Bottazzo G, Macchia E, Williams R, Eddleston AL. Antigen specific suppressor cell function in autoimmune chronic active hepatitis. Lancet. 1984; 1:1200-1204. [PubMed: 6202994]

215. Longhi MS, Ma Y, Bogdanos DP, Cheeseman P, Mieli-Vergani G, Vergani D. Impairment of CD4(+)CD25(+) regulatory T-cells in autoimmune liver disease. J Hepatol. 2004; 41:31-37. [PubMed: 15246204]

216. Longhi MS, Ma Y, Mitry RR, Bogdanos DP, Heneghan M, Cheeseman P, Mieli-Vergani G, Vergani D. Effect of CD4+ CD25+ regulatory T-cells on CD8 T-cell function in patients with autoimmune hepatitis. J Autoimmun. 2005; 25:63-71. [PubMed: 16005184]

217. Longhi MS, Meda F, Wang P, Samyn M, Mieli-Vergani G, Vergani D, Ma Y. Expansion and de novo generation of potentially therapeutic regulatory $\mathrm{T}$ cells in patients with autoimmune hepatitis. Hepatology. 2008; 47:581-591. [PubMed: 18220288]

218. Lee WY, Moriarty TJ, Wong CH, Zhou H, Strieter RM, van Rooijen N, Chaconas G, Kubes P. An intravascular immune response to Borrelia burgdorferi involves Kupffer cells and iNKT cells. Nat Immunol. 2010; 11:295-302. [PubMed: 20228796]

219. Protzer U, Maini MK, Knolle PA. Living in the liver: hepatic infections. Nat Rev Immunol. 2012; 12:201-213. [PubMed: 22362353] 
220. Keating R, Yue W, Rutigliano JA, So J, Olivas E, Thomas PG, Doherty PC. Virus-specific CD8+ $\mathrm{T}$ cells in the liver: armed and ready to kill. J Immunol. 2007; 178:2737-2745. [PubMed: 17312116]

221. Polakos NK, Klein I, Richter MV, Zaiss DM, Giannandrea M, Crispe IN, Topham DJ. Early intrahepatic accumulation of CD8+ T cells provides a source of effectors for nonhepatic immune responses. J Immunol. 2007; 179:201-210. [PubMed: 17579039]

222. Paust S, Gill HS, Wang BZ, Flynn MP, Moseman EA, Senman B, Szczepanik M, Telenti A, Askenase PW, Compans RW, von Andrian UH. Critical role for the chemokine receptor CXCR6 in NK cell-mediated antigen-specific memory of haptens and viruses. Nat Immunol. 2010; 11:1127-1135. [PubMed: 20972432]

223. Baer K, Roosevelt M, Clarkson AB Jr, van Rooijen N, Schnieder T, Frevert U. Kupffer cells are obligatory for Plasmodium yoelii sporozoite infection of the liver. Cell Microbiol. 2007; 9:397412. [PubMed: 16953803]

224. Wainwright H. Hepatic granulomas. Eur J Gastroenterol Hepatol. 2007; 19:93-95. [PubMed: 17272991]

225. Kleiner DE. Granulomas in the liver. Semin Diagn Pathol. 2006; 23:161-169. [PubMed: 17355089]

226. Zumla A, James DG. Granulomatous infections: etiology and classification. Clin Infect Dis. 1996; 23:146-158. [PubMed: 8816144]

227. Popov A, Abdullah Z, Wickenhauser C, Saric T, Driesen J, Hanisch FG, Domann E, Raven EL, Dehus O, Hermann C, Eggle D, Debey S, Chakraborty T, Kronke M, Utermohlen O, Schultze JL. Indoleamine 2,3-dioxygenase-expressing dendritic cells form suppurative granulomas following Listeria monocytogenes infection. J Clin Invest. 2006; 116:3160-3170. [PubMed: 17111046]

228. Egen JG, Rothfuchs AG, Feng CG, Winter N, Sher A, Germain RN. Macrophage and T cell dynamics during the development and disintegration of mycobacterial granulomas. Immunity. 2008; 28:271-284. [PubMed: 18261937]

229. Taylor JL, Hattle JM, Dreitz SA, Troudt JM, Izzo LS, Basaraba RJ, Orme IM, Matrisian LM, Izzo AA. Role for matrix metalloproteinase 9 in granuloma formation during pulmonary Mycobacterium tuberculosis infection. Infect Immun. 2006; 74:6135-6144. [PubMed: 16982845]

230. Sinnis P, Willnow TE, Briones MR, Herz J, Nussenzweig V. Remnant lipoproteins inhibit malaria sporozoite invasion of hepatocytes. J Exp Med. 1996; 184:945-954. [PubMed: 9064354]

231. Ishino T, Chinzei Y, Yuda M. Two proteins with 6-cys motifs are required for malarial parasites to commit to infection of the hepatocyte. Mol Microbiol. 2005; 58:1264-1275. [PubMed: 16313615]

232. Menard R. The journey of the malaria sporozoite through its hosts: two parasite proteins lead the way. Microbes Infect. 2000; 2:633-642. [PubMed: 10884614]

233. Mota MM, Pradel G, Vanderberg JP, Hafalla JC, Frevert U, Nussenzweig RS, Nussenzweig V, Rodriguez A. Migration of Plasmodium sporozoites through cells before infection. Science. 2001; 291:141-144. [PubMed: 11141568]

234. Ishino T, Yano K, Chinzei Y, Yuda M. Cell-passage activity is required for the malarial parasite to cross the liver sinusoidal cell layer. PLoS Biol. 2004; 2:E4. [PubMed: 14737184]

235. Ishino T, Chinzei Y, Yuda M. A Plasmodium sporozoite protein with a membrane attack complex domain is required for breaching the liver sinusoidal cell layer prior to hepatocyte infection. Cell Microbiol. 2005; 7:199-208. [PubMed: 15659064]

236. Shin SC, Vanderberg JP, Terzakis JA. Direct infection of hepatocytes by sporozoites of Plasmodium berghei. J Protozool. 1982; 29:448-454. [PubMed: 6752394]

237. Mota MM, Hafalla JC, Rodriguez A. Migration through host cells activates Plasmodium sporozoites for infection. Nat Med. 2002; 8:1318-1322. [PubMed: 12379848]

238. Cerami C, Frevert U, Sinnis P, Takacs B, Clavijo P, Santos MJ, Nussenzweig V. The basolateral domain of the hepatocyte plasma membrane bears receptors for the circumsporozoite protein of Plasmodium falciparum sporozoites. Cell. 1992; 70:1021-1033. [PubMed: 1326407]

239. Pradel G, Frevert U. Malaria sporozoites actively enter and pass through rat Kupffer cells prior to hepatocyte invasion. Hepatology. 2001; 33:1154-1165. [PubMed: 11343244] 
240. Coppi A, Natarajan R, Pradel G, Bennett BL, James ER, Roggero MA, Corradin G, Persson C, Tewari R, Sinnis P. The malaria circumsporozoite protein has two functional domains, each with distinct roles as sporozoites journey from mosquito to mammalian host. J Exp Med. 2011; 208:341-356. [PubMed: 21262960]

241. Yalaoui S, Zougbede S, Charrin S, Silvie O, Arduise C, Farhati K, Boucheix C, Mazier D, Rubinstein E, Froissard P. Hepatocyte permissiveness to Plasmodium infection is conveyed by a short and structurally conserved region of the CD81 large extracellular domain. PLoS Pathog. 2008; 4:e1000010. [PubMed: 18389082]

242. Silvie O, Rubinstein E, Franetich JF, Prenant M, Belnoue E, Renia L, Hannoun L, Eling W, Levy S, Boucheix C, Mazier D. Hepatocyte CD81 is required for Plasmodium falciparum and Plasmodium yoelii sporozoite infectivity. Nat Med. 2003; 9:93-96. [PubMed: 12483205]

243. Li S, Rodrigues M, Rodriguez D, Rodriguez JR, Esteban M, Palese P, Nussenzweig RS, Zavala F. Priming with recombinant influenza virus followed by administration of recombinant vaccinia virus induces CD8+ T-cell-mediated protective immunity against malaria. Proc Natl Acad Sci U S A. 1993; 90:5214-5218. [PubMed: 7685119]

244. Anders RF. Multiple cross-reactivities amongst antigens of Plasmodium falciparum impair the development of protective immunity against malaria. Parasite Immunol. 1986; 8:529-539. [PubMed: 3543808]

245. Kumar KA, Sano G, Boscardin S, Nussenzweig RS, Nussenzweig MC, Zavala F, Nussenzweig V. The circumsporozoite protein is an immunodominant protective antigen in irradiated sporozoites. Nature. 2006; 444:937-940. [PubMed: 17151604]

246. Schmidt NW, Podyminogin RL, Butler NS, Badovinac VP, Tucker BJ, Bahjat KS, Lauer P, Reyes-Sandoval A, Hutchings CL, Moore AC, Gilbert SC, Hill AV, Bartholomay LC, Harty JT. Memory CD8 $\mathrm{T}$ cell responses exceeding a large but definable threshold provide long-term immunity to malaria. Proc Natl Acad Sci U S A. 2008; 105:14017-14022. [PubMed: 18780790]

247. Carvalho LH, Sano G, Hafalla JC, Morrot A, Curotto de Lafaille MA, Zavala F. IL-4-secreting CD4+ T cells are crucial to the development of CD8+ T-cell responses against malaria liver stages. Nat Med. 2002; 8:166-170. [PubMed: 11821901]

248. Fattovich G. Natural history and prognosis of hepatitis B. Semin Liver Dis. 2003; 23:47-58. [PubMed: 12616450]

249. Seeff LB. Natural history of chronic hepatitis C. Hepatology. 2002; 36:S35-S46. [PubMed: 12407575]

250. Khuroo MS. Discovery of hepatitis E: the epidemic non-A, non-B hepatitis 30 years down the memory lane. Virus Res. 2011; 161:3-14. [PubMed: 21320558]

251. Ciocca M. Clinical course and consequences of hepatitis A infection. Vaccine. 2000; 18(Suppl 1):S71-S74. [PubMed: 10683554]

252. Guidotti LG, Rochford R, Chung J, Shapiro M, Purcell R, Chisari FV. Viral clearance without destruction of infected cells during acute HBV infection. Science. 1999; 284:825-829. [PubMed: 10221919]

253. Rehermann B, Nascimbeni M. Immunology of hepatitis B virus and hepatitis C virus infection. Nat Rev Immunol. 2005; 5:215-229. [PubMed: 15738952]

254. Bertoletti A, Ferrari C. Kinetics of the immune response during HBV and HCV infection. Hepatology. 2003; 38:4-13. [PubMed: 12829979]

255. Heise T, Guidotti LG, Cavanaugh VJ, Chisari FV. Hepatitis B virus RNA-binding proteins associated with cytokine-induced clearance of viral RNA from the liver of transgenic mice. $\mathrm{J}$ Virol. 1999; 73:474-481. [PubMed: 9847353]

256. Lohmann V, Korner F, Koch J, Herian U, Theilmann L, Bartenschlager R. Replication of subgenomic hepatitis C virus RNAs in a hepatoma cell line. Science. 1999; 285:110-113. [PubMed: 10390360]

257. Blight KJ, Kolykhalov AA, Rice CM. Efficient initiation of HCV RNA replication in cell culture. Science. 2000; 290:1972-1974. [PubMed: 11110665]

258. Guidotti LG, Chisari FV. Noncytolytic control of viral infections by the innate and adaptive immune response. Annu Rev Immunol. 2001; 19:65-91. [PubMed: 11244031] 
259. Kolykhalov AA, Agapov EV, Blight KJ, Mihalik K, Feinstone SM, Rice CM. Transmission of hepatitis C by intrahepatic inoculation with transcribed RNA. Science. 1997; 277:570-574. [PubMed: 9228008]

260. Bassett SE, Brasky KM, Lanford RE. Analysis of hepatitis C virus-inoculated chimpanzees reveals unexpected clinical profiles. J Virol. 1998; 72:2589-2599. [PubMed: 9525575]

261. Nascimbeni M, Mizukoshi E, Bosmann M, Major ME, Mihalik K, Rice CM, Feinstone SM, Rehermann B. Kinetics of CD4+ and CD8+ memory T-cell responses during hepatitis C virus rechallenge of previously recovered chimpanzees. J Virol. 2003; 77:4781-4793. [PubMed: 12663785]

262. Logvinoff C, Major ME, Oldach D, Heyward S, Talal A, Balfe P, Feinstone SM, Alter H, Rice $\mathrm{CM}$, McKeating JA. Neutralizing antibody response during acute and chronic hepatitis $\mathrm{C}$ virus infection. Proc Natl Acad Sci U S A. 2004; 101:10149-10154. [PubMed: 15220475]

263. Badr G, Bedard N, Abdel-Hakeem MS, Trautmann L, Willems B, Villeneuve JP, Haddad EK, Sekaly RP, Bruneau J, Shoukry NH. Early interferon therapy for hepatitis C virus infection rescues polyfunctional, long-lived CD8+ memory T cells. J Virol. 2008; 82:10017-10031. [PubMed: 18667516]

264. Shoukry NH, Grakoui A, Houghton M, Chien DY, Ghrayeb J, Reimann KA, Walker CM. Memory CD8+ T cells are required for protection from persistent hepatitis C virus infection. $\mathrm{J}$ Exp Med. 2003; 197:1645-1655. [PubMed: 12810686]

265. Thimme R, Bukh J, Spangenberg HC, Wieland S, Pemberton J, Steiger C, Govindarajan S, Purcell RH, Chisari FV. Viral and immunological determinants of hepatitis C virus clearance, persistence, and disease. Proc Natl Acad Sci U S A. 2002; 99:15661-15668. [PubMed: 12441397]

266. Thimme R, Oldach D, Chang KM, Steiger C, Ray SC, Chisari FV. Determinants of viral clearance and persistence during acute hepatitis C virus infection. J Exp Med. 2001; 194:13951406. [PubMed: 11714747]

267. Bigger CB, Brasky KM, Lanford RE. DNA microarray analysis of chimpanzee liver during acute resolving hepatitis C virus infection. J Virol. 2001; 75:7059-7066. [PubMed: 11435586]

268. Wieland S, Thimme R, Purcell RH, Chisari FV. Genomic analysis of the host response to hepatitis B virus infection. Proc Natl Acad Sci U S A. 2004; 101:6669-6674. [PubMed: 15100412]

269. Su AI, Pezacki JP, Wodicka L, Brideau AD, Supekova L, Thimme R, Wieland S, Bukh J, Purcell RH, Schultz PG, Chisari FV. Genomic analysis of the host response to hepatitis C virus infection. Proc Natl Acad Sci U S A. 2002; 99:15669-15674. [PubMed: 12441396]

270. Egger D, Wolk B, Gosert R, Bianchi L, Blum HE, Moradpour D, Bienz K. Expression of hepatitis $\mathrm{C}$ virus proteins induces distinct membrane alterations including a candidate viral replication complex. J Virol. 2002; 76:5974-5984. [PubMed: 12021330]

271. Kakimi K, Lane TE, Chisari FV, Guidotti LG. Cutting edge: Inhibition of hepatitis B virus replication by activated $\mathrm{NK} \mathrm{T}$ cells does not require inflammatory cell recruitment to the liver. $\mathrm{J}$ Immunol. 2001; 167:6701-6705. [PubMed: 11739482]

272. Baron JL, Gardiner L, Nishimura S, Shinkai K, Locksley R, Ganem D. Activation of a nonclassical NKT cell subset in a transgenic mouse model of hepatitis B virus infection. Immunity. 2002; 16:583-594. [PubMed: 11970881]

273. Wu J, Meng Z, Jiang M, Pei R, Trippler M, Broering R, Bucchi A, Sowa JP, Dittmer U, Yang D, Roggendorf M, Gerken G, Lu M, Schlaak JF. Hepatitis B virus suppresses toll-like receptormediated innate immune responses in murine parenchymal and nonparenchymal liver cells. Hepatology. 2009; 49:1132-1140. [PubMed: 19140219]

274. Wu J, Lu M, Meng Z, Trippler M, Broering R, Szczeponek A, Krux F, Dittmer U, Roggendorf M, Gerken G, Schlaak JF. Toll-like receptor-mediated control of HBV replication by nonparenchymal liver cells in mice. Hepatology. 2007; 46:1769-1778. [PubMed: 17929296]

275. Lang PA, Recher M, Honke N, Scheu S, Borkens S, Gailus N, Krings C, Meryk A, Kulawik A, Cervantes-Barragan L, Van Rooijen N, Kalinke U, Ludewig B, Hengartner H, Harris N, Haussinger D, Ohashi PS, Zinkernagel RM, Lang KS. Tissue macrophages suppress viral 
replication and prevent severe immunopathology in an interferon-I-dependent manner in mice. Hepatology. 2010; 52:25-32. [PubMed: 20578253]

276. Chang S, Dolganiuc A, Szabo G. Toll-like receptors 1 and 6 are involved in TLR2-mediated macrophage activation by hepatitis C virus core and NS3 proteins. J Leukoc Biol. 2007; 82:479_ 487. [PubMed: 17595379]

277. Dolganiuc A, Oak S, Kodys K, Golenbock DT, Finberg RW, Kurt-Jones E, Szabo G. Hepatitis C core and nonstructural 3 proteins trigger toll-like receptor 2-mediated pathways and inflammatory activation. Gastroenterology. 2004; 127:1513-1524. [PubMed: 15521019]

278. Cooper A, Tal G, Lider O, Shaul Y. Cytokine induction by the hepatitis B virus capsid in macrophages is facilitated by membrane heparan sulfate and involves TLR2. J Immunol. 2005; 175:3165-3176. [PubMed: 16116207]

279. Khakoo SI, Thio CL, Martin MP, Brooks CR, Gao X, Astemborski J, Cheng J, Goedert JJ, Vlahov D, Hilgartner M, Cox S, Little AM, Alexander GJ, Cramp ME, O'Brien SJ, Rosenberg WM, Thomas DL, Carrington M. HLA and NK cell inhibitory receptor genes in resolving hepatitis C virus infection. Science. 2004; 305:872-874. [PubMed: 15297676]

280. Guidotti LG, Borrow P, Hobbs MV, Matzke B, Gresser I, Oldstone MB, Chisari FV. Viral cross talk: intracellular inactivation of the hepatitis B virus during an unrelated viral infection of the liver. Proc Natl Acad Sci U S A. 1996; 93:4589-4594. [PubMed: 8643448]

281. Guidotti LG, Ishikawa T, Hobbs MV, Matzke B, Schreiber R, Chisari FV. Intracellular inactivation of the hepatitis B virus by cytotoxic T lymphocytes. Immunity. 1996; 4:25-36. [PubMed: 8574849]

282. Frese M, Pietschmann T, Moradpour D, Haller O, Bartenschlager R. Interferon-alpha inhibits hepatitis $\mathrm{C}$ virus subgenomic RNA replication by an MxA-independent pathway. J Gen Virol. 2001; 82:723-733. [PubMed: 11257176]

283. Ge D, Fellay J, Thompson AJ, Simon JS, Shianna KV, Urban TJ, Heinzen EL, Qiu P, Bertelsen AH, Muir AJ, Sulkowski M, McHutchison JG, Goldstein DB. Genetic variation in IL28B predicts hepatitis C treatment-induced viral clearance. Nature. 2009; 461:399-401. [PubMed: 19684573]

284. Tanaka Y, Nishida N, Sugiyama M, Kurosaki M, Matsuura K, Sakamoto N, Nakagawa M, Korenaga M, Hino K, Hige S, Ito Y, Mita E, Tanaka E, Mochida S, Murawaki Y, Honda M, Sakai A, Hiasa Y, Nishiguchi S, Koike A, Sakaida I, Imamura M, Ito K, Yano K, Masaki N, Sugauchi F, Izumi N, Tokunaga K, Mizokami M. Genome-wide association of IL28B with response to pegylated interferon-alpha and ribavirin therapy for chronic hepatitis C. Nat Genet. 2009; 41:1105-1109. [PubMed: 19749757]

285. Fischer J, Bohm S, Scholz M, Muller T, Witt H, George J, Sarrazin C, Susser S, Schott E, Suppiah V, Booth D, Stewart G, van Bommel F, Brodzinski A, Fulop B, Migaud P, Berg T. Combined effects of different IL28B gene variants on the outcome of dual combination therapy in chronic HCV type 1 infection. Hepatology. 2012

286. Suppiah V, Gaudieri S, Armstrong NJ, O'Connor KS, Berg T, Weltman M, Abate ML, Spengler U, Bassendine M, Dore GJ, Irving WL, Powell E, Hellard M, Riordan S, Matthews G, Sheridan D, Nattermann J, Smedile A, Muller T, Hammond E, Dunn D, Negro F, Bochud PY, Mallal S, Ahlenstiel G, Stewart GJ, George J, Booth DR. IL28B, HLA-C, and KIR variants additively predict response to therapy in chronic hepatitis $\mathrm{C}$ virus infection in a European Cohort: a crosssectional study. PLoS Med. 2011; 8:e1001092. [PubMed: 21931540]

287. Smith KR, Suppiah V, O'Connor K, Berg T, Weltman M, Abate ML, Spengler U, Bassendine M, Matthews G, Irving WL, Powell E, Riordan S, Ahlenstiel G, Stewart GJ, Bahlo M, George J, Booth DR. Identification of improved IL28B SNPs and haplotypes for prediction of drug response in treatment of hepatitis $\mathrm{C}$ using massively parallel sequencing in a cross-sectional European cohort. Genome Med. 2011; 3:57. [PubMed: 21884576]

288. Suppiah V, Moldovan M, Ahlenstiel G, Berg T, Weltman M, Abate ML, Bassendine M, Spengler U, Dore GJ, Powell E, Riordan S, Sheridan D, Smedile A, Fragomeli V, Muller T, Bahlo M, Stewart GJ, Booth DR, George J. IL28B is associated with response to chronic hepatitis C interferon-alpha and ribavirin therapy. Nat Genet. 2009; 41:1100-1104. [PubMed: 19749758] 
289. Amadei B, Urbani S, Cazaly A, Fisicaro P, Zerbini A, Ahmed P, Missale G, Ferrari C, Khakoo SI. Activation of natural killer cells during acute infection with hepatitis $\mathrm{C}$ virus.

Gastroenterology. 2010; 138:1536-1545. [PubMed: 20080094]

290. Pileri P, Uematsu Y, Campagnoli S, Galli G, Falugi F, Petracca R, Weiner AJ, Houghton M, Rosa D, Grandi G, Abrignani S. Binding of hepatitis C virus to CD81. Science. 1998; 282:938-941. [PubMed: 9794763]

291. Agnello V, Abel G, Elfahal M, Knight GB, Zhang QX. Hepatitis C virus and other flaviviridae viruses enter cells via low density lipoprotein receptor. Proc Natl Acad Sci U S A. 1999; 96:12766-12771. [PubMed: 10535997]

292. Scarselli E, Ansuini H, Cerino R, Roccasecca RM, Acali S, Filocamo G, Traboni C, Nicosia A, Cortese R, Vitelli A. The human scavenger receptor class B type I is a novel candidate receptor for the hepatitis C virus. EMBO J. 2002; 21:5017-5025. [PubMed: 12356718]

293. Pohlmann S, Zhang J, Baribaud F, Chen Z, Leslie GJ, Lin G, Granelli-Piperno A, Doms RW, Rice CM, McKeating JA. Hepatitis C virus glycoproteins interact with DC-SIGN and DCSIGNR. J Virol. 2003; 77:4070-4080. [PubMed: 12634366]

294. Lai WK, Sun PJ, Zhang J, Jennings A, Lalor PF, Hubscher S, McKeating JA, Adams DH. Expression of DC-SIGN and DC-SIGNR on human sinusoidal endothelium: a role for capturing hepatitis C virus particles. Am J Pathol. 2006; 169:200-208. [PubMed: 16816373]

295. Falkowska E, Durso RJ, Gardner JP, Cormier EG, Arrigale RA, Ogawa RN, Donovan GP, Maddon PJ, Olson WC, Dragic T. L-SIGN (CD209L) isoforms differently mediate transinfection of hepatoma cells by hepatitis C virus pseudoparticles. J Gen Virol. 2006; 87:25712576. [PubMed: 16894195]

296. Cormier EG, Durso RJ, Tsamis F, Boussemart L, Manix C, Olson WC, Gardner JP, Dragic T. LSIGN (CD209L) and DC-SIGN (CD209) mediate transinfection of liver cells by hepatitis C virus. Proc Natl Acad Sci U S A. 2004; 101:14067-14072. [PubMed: 15371595]

297. Gardner JP, Durso RJ, Arrigale RR, Donovan GP, Maddon PJ, Dragic T, Olson WC. L-SIGN (CD 209L) is a liver-specific capture receptor for hepatitis C virus. Proc Natl Acad Sci U S A. 2003; 100:4498-4503. [PubMed: 12676990]

298. Evans MJ, von Hahn T, Tscherne DM, Syder AJ, Panis M, Wolk B, Hatziioannou T, McKeating JA, Bieniasz PD, Rice CM. Claudin-1 is a hepatitis $\mathrm{C}$ virus co-receptor required for a late step in entry. Nature. 2007; 446:801-805. [PubMed: 17325668]

299. Ploss A, Evans MJ, Gaysinskaya VA, Panis M, You H, de Jong YP, Rice CM. Human occludin is a hepatitis C virus entry factor required for infection of mouse cells. Nature. 2009; 457:882-886. [PubMed: 19182773]

300. Lupberger J, Zeisel MB, Xiao F, Thumann C, Fofana I, Zona L, Davis C, Mee CJ, Turek M, Gorke S, Royer C, Fischer B, Zahid MN, Lavillette D, Fresquet J, Cosset FL, Rothenberg SM, Pietschmann T, Patel AH, Pessaux P, Doffoel M, Raffelsberger W, Poch O, McKeating JA, Brino L, Baumert TF. EGFR and EphA2 are host factors for hepatitis $\mathrm{C}$ virus entry and possible targets for antiviral therapy. Nat Med. 2011; 17:589-595. [PubMed: 21516087]

301. Crotta S, Stilla A, Wack A, D'Andrea A, Nuti S, D'Oro U, Mosca M, Filliponi F, Brunetto RM, Bonino F, Abrignani S, Valiante NM. Inhibition of natural killer cells through engagement of CD81 by the major hepatitis C virus envelope protein. J Exp Med. 2002; 195:35-41. [PubMed: 11781363]

302. Tseng CT, Klimpel GR. Binding of the hepatitis C virus envelope protein E2 to CD81 inhibits natural killer cell functions. J Exp Med. 2002; 195:43-49. [PubMed: 11781364]

303. Wack A, Soldaini E, Tseng C, Nuti S, Klimpel G, Abrignani S. Binding of the hepatitis C virus envelope protein E2 to CD81 provides a co-stimulatory signal for human T cells. Eur J Immunol. 2001; 31:166-175. [PubMed: 11169450]

304. Ashida M, Hamada C. Molecular cloning of the hepatitis A virus receptor from a simian cell line. J Gen Virol. 1997; 78(Pt 7):1565-1569. [PubMed: 9225030]

305. Feigelstock D, Thompson P, Mattoo P, Zhang Y, Kaplan GG. The human homolog of HAVcr-1 codes for a hepatitis A virus cellular receptor. J Virol. 1998; 72:6621-6628. [PubMed: 9658108] 
306. Stockert RJ, Kressner MS, Collins JC, Sternlieb I, Morell AG. IgA interaction with the asialoglycoprotein receptor. Proc Natl Acad Sci U S A. 1982; 79:6229-6231. [PubMed: 6292896]

307. Tomana M, Kulhavy R, Mestecky J. Receptor-mediated binding and uptake of immunoglobulin A by human liver. Gastroenterology. 1988; 94:762-770. [PubMed: 3338646]

308. Dotzauer A, Gebhardt U, Bieback K, Gottke U, Kracke A, Mages J, Lemon SM, Vallbracht A. Hepatitis A virus-specific immunoglobulin A mediates infection of hepatocytes with hepatitis A virus via the asialoglycoprotein receptor. J Virol. 2000; 74:10950-10957. [PubMed: 11069989]

309. van Egmond M, van Garderen E, van Spriel AB, Damen CA, van Amersfoort ES, van Zandbergen G, van Hattum J, Kuiper J, van de Winkel JG. FcalphaRI-positive liver Kupffer cells: reappraisal of the function of immunoglobulin A in immunity. Nat Med. 2000; 6:680-685. [PubMed: 10835685]

310. Thimme R, Wieland S, Steiger C, Ghrayeb J, Reimann KA, Purcell RH, Chisari FV. CD8(+) T cells mediate viral clearance and disease pathogenesis during acute hepatitis $\mathrm{B}$ virus infection. $\mathrm{J}$ Virol. 2003; 77:68-76. [PubMed: 12477811]

311. Grakoui A, Shoukry NH, Woollard DJ, Han JH, Hanson HL, Ghrayeb J, Murthy KK, Rice CM, Walker CM. HCV persistence and immune evasion in the absence of memory T cell help. Science. 2003; 302:659-662. [PubMed: 14576438]

312. Garcia-Rodriguez MJ, Canales MA, Hernandez-Maraver D, Hernandez-Navarro F. Late reactivation of resolved hepatitis $\mathrm{B}$ virus infection: an increasing complication post rituximabbased regimens treatment? Am J Hematol. 2008; 83:673-675. [PubMed: 18528824]

313. Brimacombe CL, Grove J, Meredith LW, Hu K, Syder AJ, Flores MV, Timpe JM, Krieger SE, Baumert TF, Tellinghuisen TL, Wong-Staal F, Balfe P, McKeating JA. Neutralizing antibodyresistant hepatitis C virus cell-to-cell transmission. J Virol. 2011; 85:596-605. [PubMed: 20962076]

314. von Hahn T, Yoon JC, Alter H, Rice CM, Rehermann B, Balfe P, McKeating JA. Hepatitis C virus continuously escapes from neutralizing antibody and T-cell responses during chronic infection in vivo. Gastroenterology. 2007; 132:667-678. [PubMed: 17258731]

315. Lopes AR, Kellam P, Das A, Dunn C, Kwan A, Turner J, Peppa D, Gilson RJ, Gehring A, Bertoletti A, Maini MK. Bim-mediated deletion of antigen-specific CD8 T cells in patients unable to control HBV infection. J Clin Invest. 2008; 118:1835-1845. [PubMed: 18398508]

316. Radziewicz H, Ibegbu CC, Hon H, Osborn MK, Obideen K, Wehbi M, Freeman GJ, Lennox JL, Workowski KA, Hanson HL, Grakoui A. Impaired hepatitis C virus (HCV)-specific effector CD8+ T cells undergo massive apoptosis in the peripheral blood during acute HCV infection and in the liver during the chronic phase of infection. J Virol. 2008; 82:9808-9822. [PubMed: 18667503]

317. Larrubia JR, Benito-Martinez S, Miquel J, Calvino M, Sanz-de-Villalobos E, Gonzalez-Praetorius A, Albertos S, Garcia-Garzon S, Lokhande M, Parra-Cid T. Bim-mediated apoptosis and PD-1/PD-L1 pathway impair reactivity of PD1(+)/CD127(-) HCV-specific CD8(+) cells targeting the virus in chronic hepatitis $C$ virus infection. Cell Immunol. 2011; 269:104-114. [PubMed: 21481848]

318. Kantzanou M, Lucas M, Barnes E, Komatsu H, Dusheiko G, Ward S, Harcourt G, Klenerman P. Viral escape and $\mathrm{T}$ cell exhaustion in hepatitis $\mathrm{C}$ virus infection analysed using Class I peptide tetramers. Immunol Lett. 2003; 85:165-171. [PubMed: 12527224]

319. Klenerman P, Lechner F, Kantzanou M, Ciurea A, Hengartner H, Zinkernagel R. Viral escape and the failure of cellular immune responses. Science. 2000; 289:2003. [PubMed: 11032545]

320. Blackburn SD, Shin H, Haining WN, Zou T, Workman CJ, Polley A, Betts MR, Freeman GJ, Vignali DA, Wherry EJ. Coregulation of CD8+ T cell exhaustion by multiple inhibitory receptors during chronic viral infection. Nat Immunol. 2009; 10:29-37. [PubMed: 19043418]

321. Boni C, Fisicaro P, Valdatta C, Amadei B, Di Vincenzo P, Giuberti T, Laccabue D, Zerbini A, Cavalli A, Missale G, Bertoletti A, Ferrari C. Characterization of hepatitis B virus (HBV)specific T-cell dysfunction in chronic HBV infection. J Virol. 2007; 81:4215-4225. [PubMed: $17287266]$ 
322. Peng G, Li S, Wu W, Tan X, Chen Y, Chen Z. PD-1 upregulation is associated with HBVspecific T cell dysfunction in chronic hepatitis B patients. Mol Immunol. 2008; 45:963-970. [PubMed: 17868872]

323. Urbani S, Amadei B, Tola D, Pedrazzi G, Sacchelli L, Cavallo MC, Orlandini A, Missale G, Ferrari C. Restoration of HCV-specific T cell functions by PD-1/PD-L1 blockade in HCV infection: effect of viremia levels and antiviral treatment. J Hepatol. 2008; 48:548-558. [PubMed: 18280607]

324. Urbani S, Amadei B, Tola D, Massari M, Schivazappa S, Missale G, Ferrari C. PD-1 expression in acute hepatitis $\mathrm{C}$ virus (HCV) infection is associated with $\mathrm{HCV}$-specific CD8 exhaustion. $\mathrm{J}$ Virol. 2006; 80:11398-11403. [PubMed: 16956940]

325. Bengsch B, Seigel B, Ruhl M, Timm J, Kuntz M, Blum HE, Pircher H, Thimme R. Coexpression of PD-1, 2B4, CD160 and KLRG1 on exhausted HCV-specific CD8+ T cells is linked to antigen recognition and T cell differentiation. PLoS Pathog. 2010; 6:e1000947. [PubMed: 20548953]

326. Iwai Y, Terawaki S, Ikegawa M, Okazaki T, Honjo T. PD-1 inhibits antiviral immunity at the effector phase in the liver. J Exp Med. 2003; 198:39-50. [PubMed: 12847136]

327. Muhlbauer M, Fleck M, Schutz C, Weiss T, Froh M, Blank C, Scholmerich J, Hellerbrand C. PD$\mathrm{L} 1$ is induced in hepatocytes by viral infection and by interferon-alpha and -gamma and mediates T cell apoptosis. J Hepatol. 2006; 45:520-528. [PubMed: 16876901]

328. Zhang Z, Zhang JY, Wherry EJ, Jin B, Xu B, Zou ZS, Zhang SY, Li BS, Wang HF, Wu H, Lau GK, Fu YX, Wang FS. Dynamic programmed death 1 expression by virus-specific CD8 T cells correlates with the outcome of acute hepatitis B. Gastroenterology. 2008; 134:1938-1949. 1949 e1-1949 e3. [PubMed: 18455515]

329. Kassel R, Cruise MW, Iezzoni JC, Taylor NA, Pruett TL, Hahn YS. Chronically inflamed livers up-regulate expression of inhibitory B7 family members. Hepatology. 2009; 50:1625-1637. [PubMed: 19739236]

330. Mengshol JA, Golden-Mason L, Arikawa T, Smith M, Niki T, McWilliams R, Randall JA, McMahan R, Zimmerman MA, Rangachari M, Dobrinskikh E, Busson P, Polyak SJ, Hirashima M, Rosen HR. A crucial role for Kupffer cell-derived galectin-9 in regulation of T cell immunity in hepatitis C infection. PLoS One. 2010; 5:e9504. [PubMed: 20209097]

331. Barber DL, Wherry EJ, Masopust D, Zhu B, Allison JP, Sharpe AH, Freeman GJ, Ahmed R. Restoring function in exhausted CD8 T cells during chronic viral infection. Nature. 2006; 439:682-687. [PubMed: 16382236]

332. Ferrari C, Penna A, Bertoletti A, Valli A, Antoni AD, Giuberti T, Cavalli A, Petit MA, Fiaccadori F. Cellular immune response to hepatitis B virus-encoded antigens in acute and chronic hepatitis B virus infection. J Immunol. 1990; 145:3442-3449. [PubMed: 2230128]

333. Bogdanos DP, Mieli-Vergani G, Vergani D. Virus, liver and autoimmunity. Dig Liver Dis. 2000; 32:440-446. [PubMed: 11030191]

334. Bogdanos DP, Choudhuri K, Vergani D. Molecular mimicry and autoimmune liver disease: virtuous intentions, malign consequences. Liver. 2001; 21:225-232. [PubMed: 11454184]

335. Bogdanos DP, Mieli-Vergani G, Vergani D. Non-organ-specific autoantibodies in children with chronic hepatitis C virus infection. Clin Infect Dis. 2004; 38:1505. author reply 1505-6. [PubMed: 15156495]

336. Bogdanos DP, Mieli-Vergani G, Vergani D. Non-organ-specific autoantibodies in hepatitis C virus infection: do they matter? Clin Infect Dis. 2005; 40:508-510. [PubMed: 15712071]

337. Bogdanos DP, Smith H, Ma Y, Baum H, Mieli-Vergani G, Vergani D. A study of molecular mimicry and immunological cross-reactivity between hepatitis B surface antigen and myelin mimics. Clin Dev Immunol. 2005; 12:217-224. [PubMed: 16295528]

338. Gregorio GV, Choudhuri K, Ma Y, Pensati P, Iorio R, Grant P, Garson J, Bogdanos DP, Vegnente A, Mieli-Vergani G, Vergani D. Mimicry between the hepatitis C virus polyprotein and antigenic targets of nuclear and smooth muscle antibodies in chronic hepatitis $\mathrm{C}$ virus infection. Clin Exp Immunol. 2003; 133:404-413. [PubMed: 12930368]

339. Dammacco F, Sansonno D, Piccoli C, Racanelli V, D'Amore FP, Lauletta G. The lymphoid system in hepatitis $\mathrm{C}$ virus infection: autoimmunity, mixed cryoglobulinemia, and Overt B-cell malignancy. Semin Liver Dis. 2000; 20:143-157. [PubMed: 10946420] 
340. Vento S, Cainelli F. Is there a role for viruses in triggering autoimmune hepatitis? Autoimmun Rev. 2004; 3:61-69. [PubMed: 14871651]

341. Mackie FD, Peakman M, Yun M, Sallie R, Smith H, Davies ET, Mieli-Vergani G, Vergani D. Primary and secondary liver/kidney microsomal autoantibody response following infection with hepatitis C virus. Gastroenterology. 1994; 106:1672-1675. [PubMed: 8194716]

342. Bogdanos DP, Lenzi M, Okamoto M, Rigopoulou EI, Muratori P, Ma Y, Muratori L, Tsantoulas D, Mieli- Vergani G, Bianchi FB, Vergani D. Multiple viral/self immunological cross-reactivity in liver kidney microsomal antibody positive hepatitis $\mathrm{C}$ virus infected patients is associated with the possession of HLA B51. Int J Immunopathol Pharmacol. 2004; 17:83-92. [PubMed: 15000871]

343. Altekruse SF, McGlynn KA, Reichman ME. Hepatocellular carcinoma incidence, mortality, and survival trends in the United States from 1975 to 2005. J Clin Oncol. 2009; 27:1485-1491. [PubMed: 19224838]

344. El-Serag HB, Marrero JA, Rudolph L, Reddy KR. Diagnosis and treatment of hepatocellular carcinoma. Gastroenterology. 2008; 134:1752-1763. [PubMed: 18471552]

345. Chang MH, Chen CJ, Lai MS, Hsu HM, Wu TC, Kong MS, Liang DC, Shau WY, Chen DS. Universal hepatitis B vaccination in Taiwan and the incidence of hepatocellular carcinoma in children. Taiwan Childhood Hepatoma Study Group. The New England journal of medicine. 1997; 336:1855-1859. [PubMed: 9197213]

346. Butterfield LH, Ribas A, Meng WS, Dissette VB, Amarnani S, Vu HT, Seja E, Todd K, Glaspy JA, McBride WH, Economou JS. T-cell responses to HLA-A*0201 immunodominant peptides derived from alpha-fetoprotein in patients with hepatocellular cancer. Clin Cancer Res. 2003; 9:5902-5908. [PubMed: 14676113]

347. Butterfield LH, Meng WS, Koh A, Vollmer CM, Ribas A, Dissette VB, Faull K, Glaspy JA, McBride WH, Economou JS. T cell responses to HLA-A*0201-restricted peptides derived from human alpha fetoprotein. J Immunol. 2001; 166:5300-5308. [PubMed: 11290817]

348. Butterfield LH, Koh A, Meng W, Vollmer CM, Ribas A, Dissette V, Lee E, Glaspy JA, McBride WH, Economou JS. Generation of human T-cell responses to an HLA-A2.1-restricted peptide epitope derived from alpha-fetoprotein. Cancer Res. 1999; 59:3134-3142. [PubMed: 10397256]

349. Thimme R, Neagu M, Boettler T, Neumann-Haefelin C, Kersting N, Geissler M, Makowiec F, Obermaier R, Hopt UT, Blum HE, Spangenberg HC. Comprehensive analysis of the alphafetoprotein-specific CD8+ T cell responses in patients with hepatocellular carcinoma. Hepatology. 2008; 48:1821-1833. [PubMed: 19003875]

350. Wada Y, Nakashima O, Kutami R, Yamamoto O, Kojiro M. Clinicopathological study on hepatocellular carcinoma with lymphocytic infiltration. Hepatology. 1998; 27:407-414. [PubMed: 9462638]

351. Hiroishi K, Eguchi J, Baba T, Shimazaki T, Ishii S, Hiraide A, Sakaki M, Doi H, Uozumi S, Omori R, Matsumura T, Yanagawa T, Ito T, Imawari M. Strong CD8(+) T-cell responses against tumor-associated antigens prolong the recurrence-free interval after tumor treatment in patients with hepatocellular carcinoma. J Gastroenterol. 2010; 45:451-458. [PubMed: 19936602]

352. Fu J, Xu D, Liu Z, Shi M, Zhao P, Fu B, Zhang Z, Yang H, Zhang H, Zhou C, Yao J, Jin L, Wang $\mathrm{H}$, Yang Y, Fu YX, Wang FS. Increased regulatory T cells correlate with CD8 T-cell impairment and poor survival in hepatocellular carcinoma patients. Gastroenterology. 2007; 132:2328-2339. [PubMed: 17570208]

353. Ormandy LA, Hillemann T, Wedemeyer H, Manns MP, Greten TF, Korangy F. Increased populations of regulatory $\mathrm{T}$ cells in peripheral blood of patients with hepatocellular carcinoma. Cancer Res. 2005; 65:2457-2464. [PubMed: 15781662]

354. Shimizu J, Yamazaki S, Sakaguchi S. Induction of tumor immunity by removing CD25+CD4+ T cells: a common basis between tumor immunity and autoimmunity. J Immunol. 1999; 163:52115218. [PubMed: 10553041]

355. Golgher D, Jones E, Powrie F, Elliott T, Gallimore A. Depletion of CD25+ regulatory cells uncovers immune responses to shared murine tumor rejection antigens. Eur J Immunol. 2002; 32:3267-3275. [PubMed: 12555672] 
356. Aksoylar HI, Lampe K, Barnes MJ, Plas DR, Hoebe K. Loss of immunological tolerance in Gimap5-deficient mice is associated with loss of Foxo in CD4+ T cells. J Immunol. 2012; 188:146-154. [PubMed: 22106000]

357. Baughman EJ, Mendoza JP, Ortega SB, Ayers CL, Greenberg BM, Frohman EM, Karandikar NJ. Neuroantigen-specific CD8+ regulatory T-cell function is deficient during acute exacerbation of multiple sclerosis. J Autoimmun. 2011; 36:115-124. [PubMed: 21257291]

358. Kerzerho J, Wunsch D, Szely N, Meyer HA, Lurz L, Rose L, Wahn U, Akbari O, Stock P. Effects of systemic versus local administration of corticosteroids on mucosal tolerance. J Immunol. 2012; 188:470-476. [PubMed: 22105997]

359. Laakso SM, Laurinolli TT, Rossi LH, Lehtoviita A, Sairanen H, Perheentupa J, Kekalainen E, Arstila TP. Regulatory T cell defect in APECED patients is associated with loss of naive FOXP3(+) precursors and impaired activated population. J Autoimmun. 2010; 35:351-357. [PubMed: 20805020]

360. Li CR, Deiro MF, Godebu E, Bradley LM. IL-7 uniquely maintains FoxP3(+) adaptive Treg cells that reverse diabetes in NOD mice via integrin-beta7-dependent localization. J Autoimmun. 2011; 37:217-227. [PubMed: 21745722]

361. Martinez RJ, Zhang N, Thomas SR, Nandiwada SL, Jenkins MK, Binstadt BA, Mueller DL. Arthritogenic self-reactive CD4+ T cells acquire an FR4hiCD73hi anergic state in the presence of Foxp3+ regulatory T cells. J Immunol. 2012; 188:170-181. [PubMed: 22124124]

362. Miyagawa F, Gutermuth J, Zhang H, Katz SI. The use of mouse models to better understand mechanisms of autoimmunity and tolerance. J Autoimmun. 2010; 35:192-198. [PubMed: 20655706]

363. Munoz-Suano A, Kallikourdis M, Sarris M, Betz AG. Regulatory T cells protect from autoimmune arthritis during pregnancy. J Autoimmun. 2011

364. Ray A, Basu S, Williams CB, Salzman NH, Dittel BN. A Novel IL-10-Independent Regulatory Role for B Cells in Suppressing Autoimmunity by Maintenance of Regulatory T Cells via GITR Ligand. J Immunol. 2012

365. Santiuste I, Buelta L, Iglesias M, Genre F, Mazorra F, Izui S, Merino J, Merino R. B-cell overexpression of Bcl-2 cooperates with p21 deficiency for the induction of autoimmunity and lymphomas. J Autoimmun. 2010; 35:316-324. [PubMed: 20691570]

366. Wang YH, Yan Y, Rice JS, Volpe BT, Diamond B. Enforced expression of the apoptosis inhibitor Bcl-2 ablates tolerance induction in DNA-reactive B cells through a novel mechanism. J Autoimmun. 2011; 37:18-27. [PubMed: 21458954]

367. Xiao X, Gong W, Demirci G, Liu W, Spoerl S, Chu X, Bishop DK, Turka LA, Li XC. New insights on OX40 in the control of T cell immunity and immune tolerance in vivo. J Immunol. 2012; 188:892-901. [PubMed: 22147766]

368. Zhang AH, Li X, Onabajo OO, Su Y, Skupsky J, Thomas JW, Scott DW. B-cell delivered gene therapy for tolerance induction: role of autoantigen-specific B cells. J Autoimmun. 2010; 35:107-113. [PubMed: 20579844]

369. Zhao Q, Kuang DM, Wu Y, Xiao X, Li XF, Li TJ, Zheng L. Activated CD69+ T cells foster immune privilege by regulating IDO expression in tumor-associated macrophages. J Immunol. 2012; 188:1117-1124. [PubMed: 22184722]

370. Chen M, Felix K, Wang J. Immune regulation through mitochondrion-dependent dendritic cell death induced by T regulatory cells. J Immunol. 2011; 187:5684-5692. [PubMed: 22031758]

371. Chang C, Gershwin ME. Drugs and autoimmunity--a contemporary review and mechanistic approach. J Autoimmun. 2010; 34:J266-J275. [PubMed: 20015613]

372. Kim DH, Lee JC, Kim S, Oh SH, Lee MK, Kim KW, Lee MS. Inhibition of autoimmune diabetes by TLR2 tolerance. J Immunol. 2011; 187:5211-5220. [PubMed: 21998452]

373. Verkoczy L, Chen Y, Bouton-Verville H, Zhang J, Diaz M, Hutchinson J, Ouyang YB, Alam SM, Holl TM, Hwang KK, Kelsoe G, Haynes BF. Rescue of HIV-1 broad neutralizing antibodyexpressing B cells in 2F5 VH $\times$ VL knockin mice reveals multiple tolerance controls. J Immunol. 2011; 187:3785-3797. [PubMed: 21908739]

374. Round JL, O'Connell RM, Mazmanian SK. Coordination of tolerogenic immune responses by the commensal microbiota. J Autoimmun. 2010; 34:J220-J225. [PubMed: 19963349] 
375. Christen U, Hintermann E, Holdener M, von Herrath MG. Viral triggers for autoimmunity: is the 'glass of molecular mimicry' half full or half empty? J Autoimmun. 2010; 34:38-44. [PubMed: 19716269]

376. Goldstone AB, Bronster DJ, Anyanwu AC, Goldstein MA, Filsoufi F, Adams DH, Chikwe J. Predictors and outcomes of seizures after cardiac surgery: a multivariable analysis of 2,578 patients. Ann Thorac Surg. 2011; 91:514-518. [PubMed: 21256303]

377. Humphreys EH, Williams KT, Adams DH, Afford SC. Primary and malignant cholangiocytes undergo CD40 mediated Fas dependent apoptosis, but are insensitive to direct activation with exogenous Fas ligand. PLoS One. 2010; 5:e14037. [PubMed: 21103345]

378. Oo YH, Shetty S, Adams DH. The role of chemokines in the recruitment of lymphocytes to the liver. Dig Dis. 2010; 28:31-44. [PubMed: 20460888]

379. Weston CJ, Adams DH. Hepatic consequences of vascular adhesion protein-1 expression. J Neural Transm. 2011; 118:1055-1064. [PubMed: 21512782]

380. Adams DH, Ju C, Ramaiah SK, Uetrecht J, Jaeschke H. Mechanisms of immune-mediated liver injury. Toxicol Sci. 2010; 115:307-321. [PubMed: 20071422]

381. Luth S, Huber S, Schramm C, Buch T, Zander S, Stadelmann C, Bruck W, Wraith DC, Herkel J, Lohse AW. Ectopic expression of neural autoantigen in mouse liver suppresses experimental autoimmune neuroinflammation by inducing antigen-specific Tregs. J Clin Invest. 2008; 118:3403-3410. [PubMed: 18802476]

382. Scoazec JY, Feldmann G. In situ immunophenotyping study of endothelial cells of the human hepatic sinusoid: results and functional implications. Hepatology. 1991; 14:789-797. [PubMed: 1937383]

383. Scoazec JY, Feldmann G. The cell adhesion molecules of hepatic sinusoidal endothelial cells. J Hepatol. 1994; 20:296-300. [PubMed: 8006410]

384. Pusztaszeri MP, Seelentag W, Bosman FT. Immunohistochemical expression of endothelial markers CD31, CD34, von Willebrand factor, and Fli-1 in normal human tissues. J Histochem Cytochem. 2006; 54:385-395. [PubMed: 16234507]

385. Mousa SA. Expression of adhesion molecules during cadmium hepatotoxicity. Life Sci. 2004; 75:93-105. [PubMed: 15102524]

386. Daneker GW, Lund SA, Caughman SW, Swerlick RA, Fischer AH, Staley CA, Ades EW. Culture and characterization of sinusoidal endothelial cells isolated from human liver. In Vitro Cell Dev Biol Anim. 1998; 34:370-377. [PubMed: 9639099]

387. Matsumura T, Takesue M, Westerman KA, Okitsu T, Sakaguchi M, Fukazawa T, Totsugawa T, Noguchi H, Yamamoto S, Stolz DB, Tanaka N, Leboulch P, Kobayashi N. Establishment of an immortalized human-liver endothelial cell line with SV40T and hTERT. Transplantation. 2004; 77:1357-1365. [PubMed: 15167590]

388. Karrar A, Broome U, Uzunel M, Qureshi AR, Sumitran-Holgersson S. Human liver sinusoidal endothelial cells induce apoptosis in activated T cells: a role in tolerance induction. Gut. 2007; 56:243-252. [PubMed: 16840505]

389. Irving MG, Roll FJ, Huang S, Bissell DM. Characterization and culture of sinusoidal endothelium from normal rat liver: lipoprotein uptake and collagen phenotype. Gastroenterology. 1984; 87:1233-1247. [PubMed: 6092194]

390. van der Kwast TH, Stel HV, Cristen E, Bertina RM, Veerman EC. Localization of factor VIIIprocoagulant antigen: an immunohistological survey of the human body using monoclonal antibodies. Blood. 1986; 67:222-227. [PubMed: 3079642]

391. Smedsrod B, Pertoft H, Gustafson S, Laurent TC. Scavenger functions of the liver endothelial cell. Biochem J. 1990; 266:313-327. [PubMed: 2156492]

392. Homberg JC, Abuaf N, Bernard O, Islam S, Alvarez F, Khalil SH, Poupon R, Darnis F, Levy VG, Grippon $\mathrm{P}$, et al. Chronic active hepatitis associated with antiliver/kidney microsome antibody type 1: a second type of "autoimmune" hepatitis. Hepatology. 1987; 7:1333-1339. [PubMed: 3679093]

393. Kerkar N, Choudhuri K, Ma Y, Mahmoud A, Bogdanos DP, Muratori L, Bianchi F, Williams R, Mieli-Vergani G, Vergani D. Cytochrome P4502D6(193-212): a new immunodominant epitope 
and target of virus/self cross-reactivity in liver kidney microsomal autoantibody type 1-positive liver disease. J Immunol. 2003; 170:1481-1489. [PubMed: 12538711]

394. Dalekos GN, Wedemeyer H, Obermayer-Straub P, Kayser A, Barut A, Frank H, Manns MP. Epitope mapping of cytochrome P4502D6 autoantigen in patients with chronic hepatitis $\mathrm{C}$ during alpha-interferon treatment. J Hepatol. 1999; 30:366-375. [PubMed: 10190716]

395. Manns MP, Griffin KJ, Sullivan KF, Johnson EF. LKM-1 autoantibodies recognize a short linear sequence in P450IID6, a cytochrome P-450 monooxygenase. J Clin Invest. 1991; 88:1370-1378. [PubMed: 1717511]

396. Ma Y, Thomas MG, Okamoto M, Bogdanos DP, Nagl S, Kerkar N, Lopes AR, Muratori L, Lenzi M, Bianchi FB, Mieli-Vergani G, Vergani D. Key residues of a major cytochrome P4502D6 epitope are located on the surface of the molecule. J Immunol. 2002; 169:277-285. [PubMed: 12077255] 


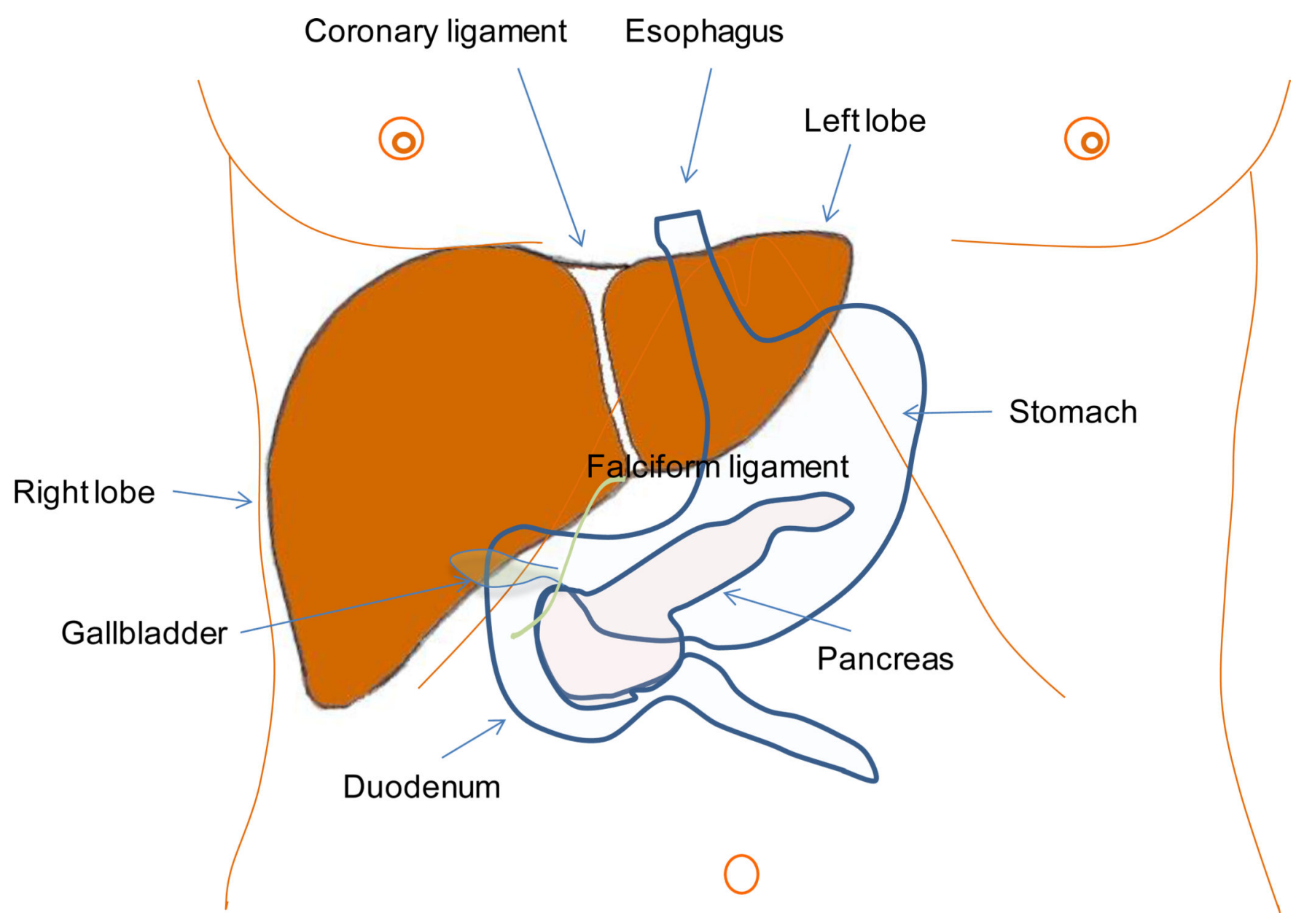

Figure 1.

Anatomical location and external appearance of the liver. The falciform ligament, on the surface of the diaphragm, splits the liver into right and left lobe. The anatomical relationship of the liver with organs such as the gallbladder, stomach, duodenum, and pancreas is illustrated. 


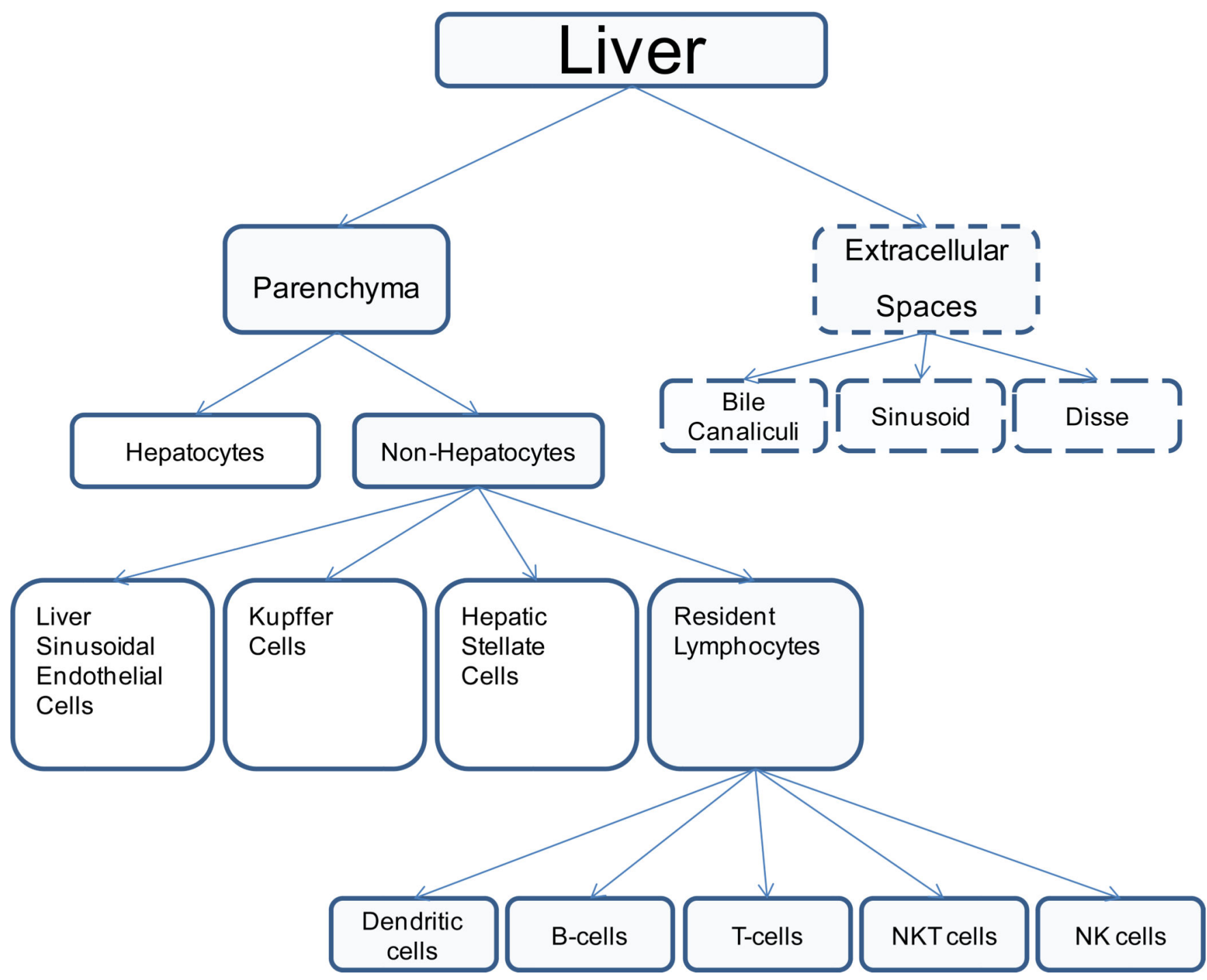

Figure 2.

Cellular and extracellular composition of the liver 


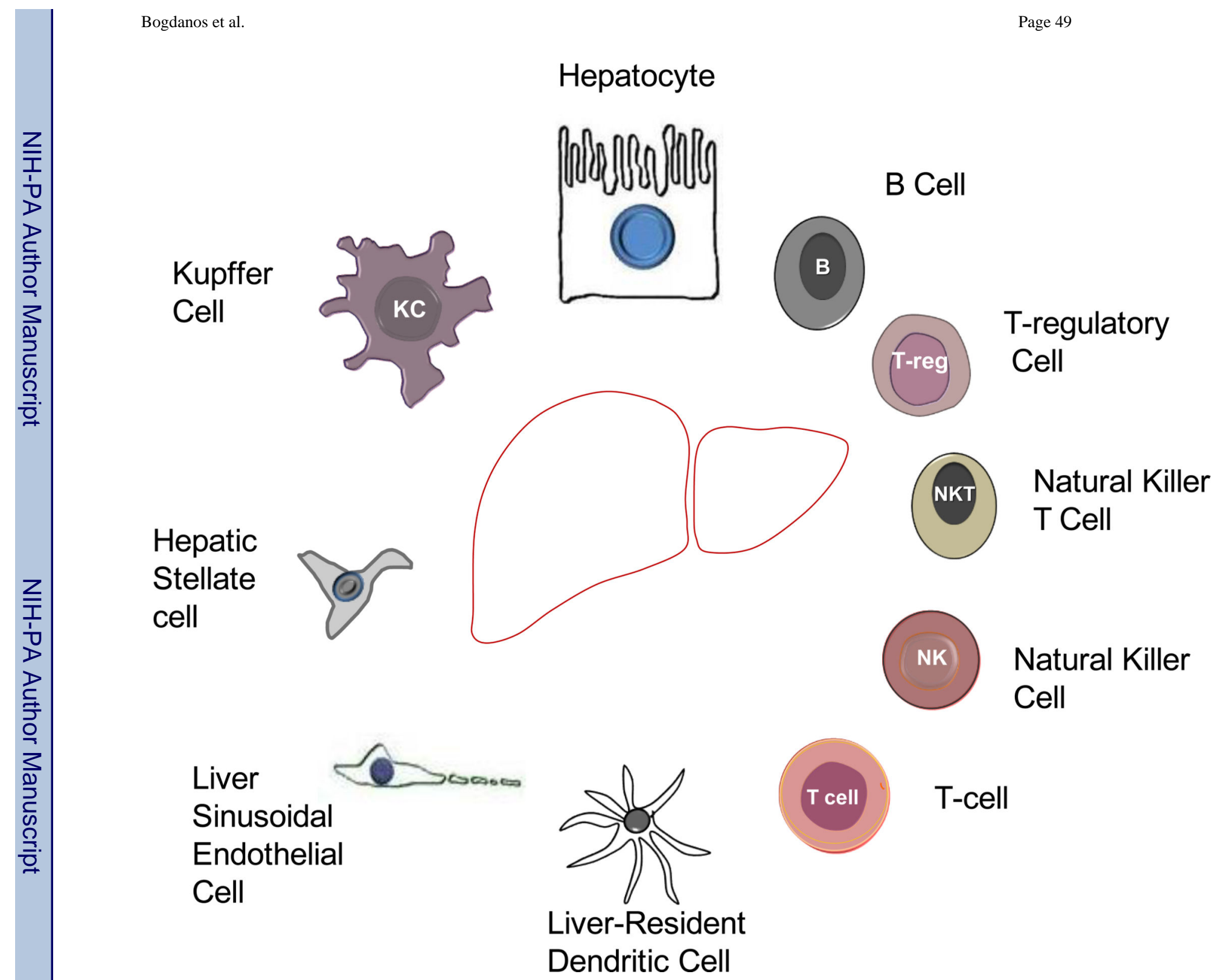

Figure 3.

The morphological appearance of cells within the liver. 


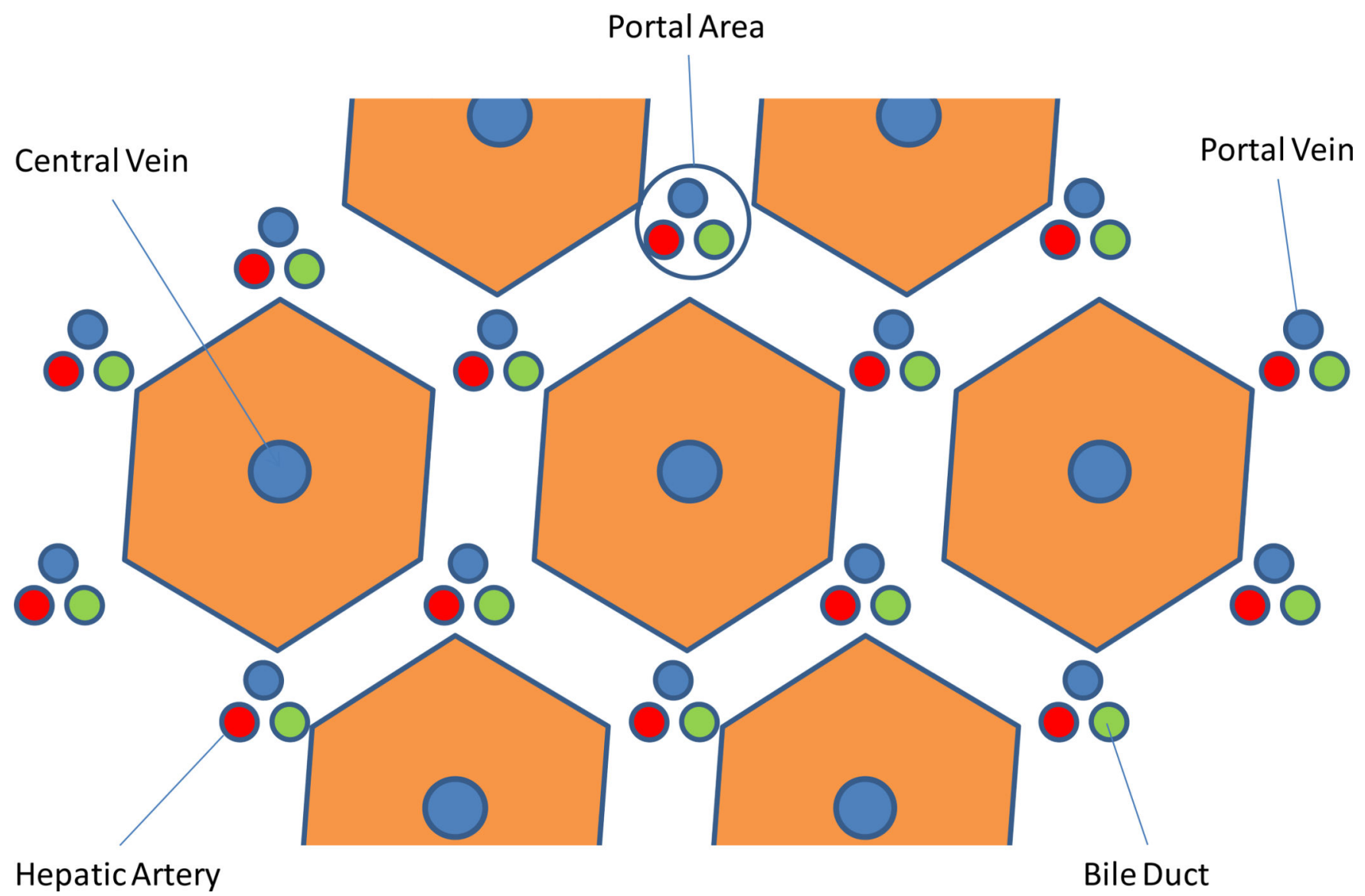

Figure 4.

The hepatic lobule is the structural unit of the liver. It consists of an hexagonal arrangement of hepatocyte plates with the central vein located in the center of the structure and the portal triads distributed at the vertices of the lobule. The portal triad consists of terminal branches of the portal vein and the hepatic artery and a bile duct. 


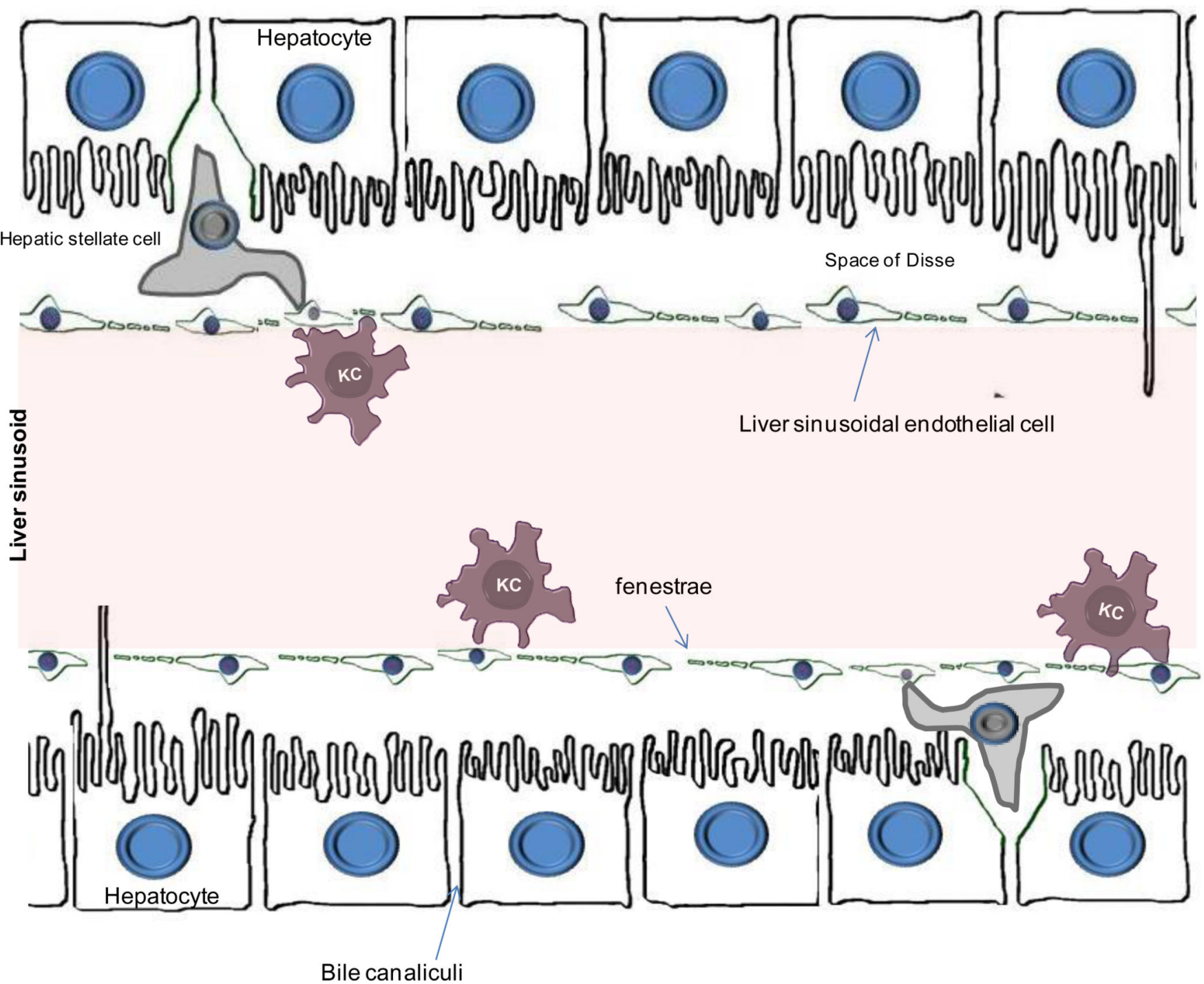

Figure 5.

Illustration of the microanatomical localization of hepatocytes, liver sinusoidal endothelial cells, Kupffer cells, and hepatic stellate cells. The space of Disse separates hepatocytes from the liver sinusoids. The endothelium of liver sinusoids is discontinued (fenestrated) and is formed by a layer of liver sinusoidal endothelial cells ${ }^{16}$. These cells act as scavenger cells and form a physical filtering barrier between the sinusoidal blood and plasma ${ }^{69,}{ }^{391}$. Kupffer cells are resident macrophages, that are attached to the layer of liver sinusoidal endothelial cells. The hepatic stellate cells are located in the sub-endothelial space of Disse and play vital role in fibrogenesis. 


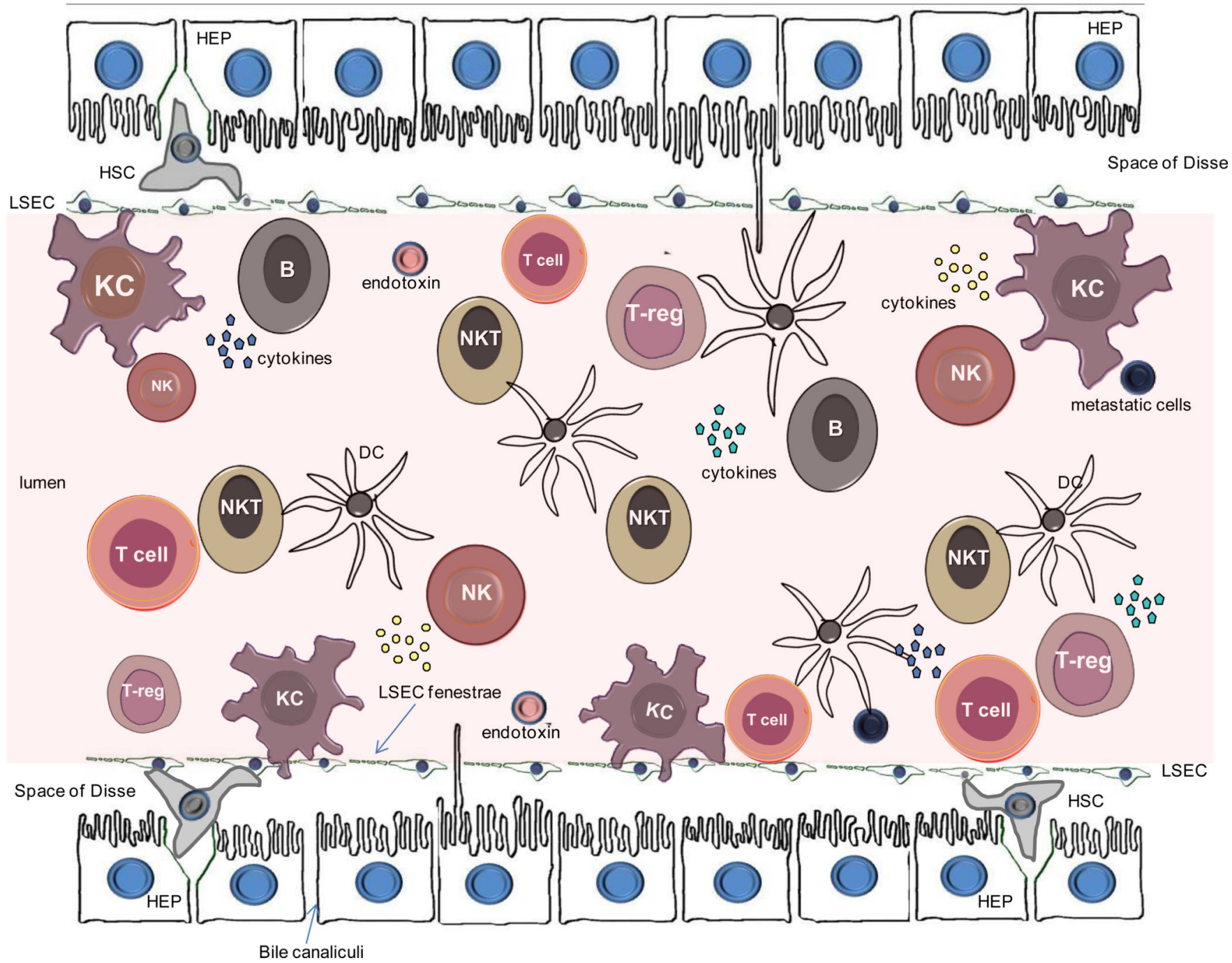

Figure 6.

Cells comprising the liver including hepatocytes (HEP), liver sinusoidal ensothelial cells (LSEC), Kupffer cells (KC), hepatic stellate cells (HSC) and lymphoid cell sub-populations. NK, natural killer; NKT, natural killer T-cells; DC, dendritic cell; Treg, T-regulatory cell 


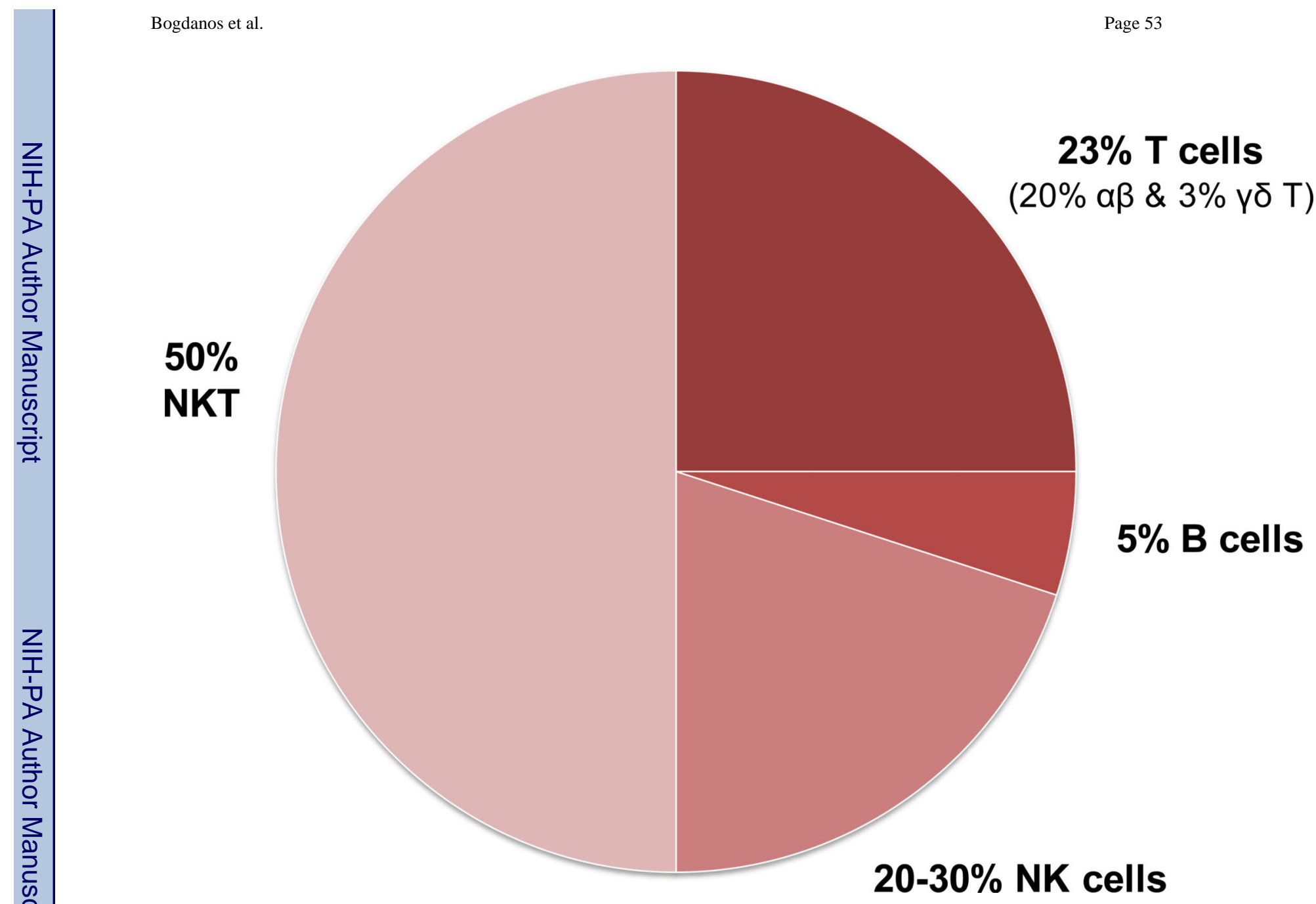

Figure 7.

Distribution of cell sub-populations within intrahepatic lymphocytes 

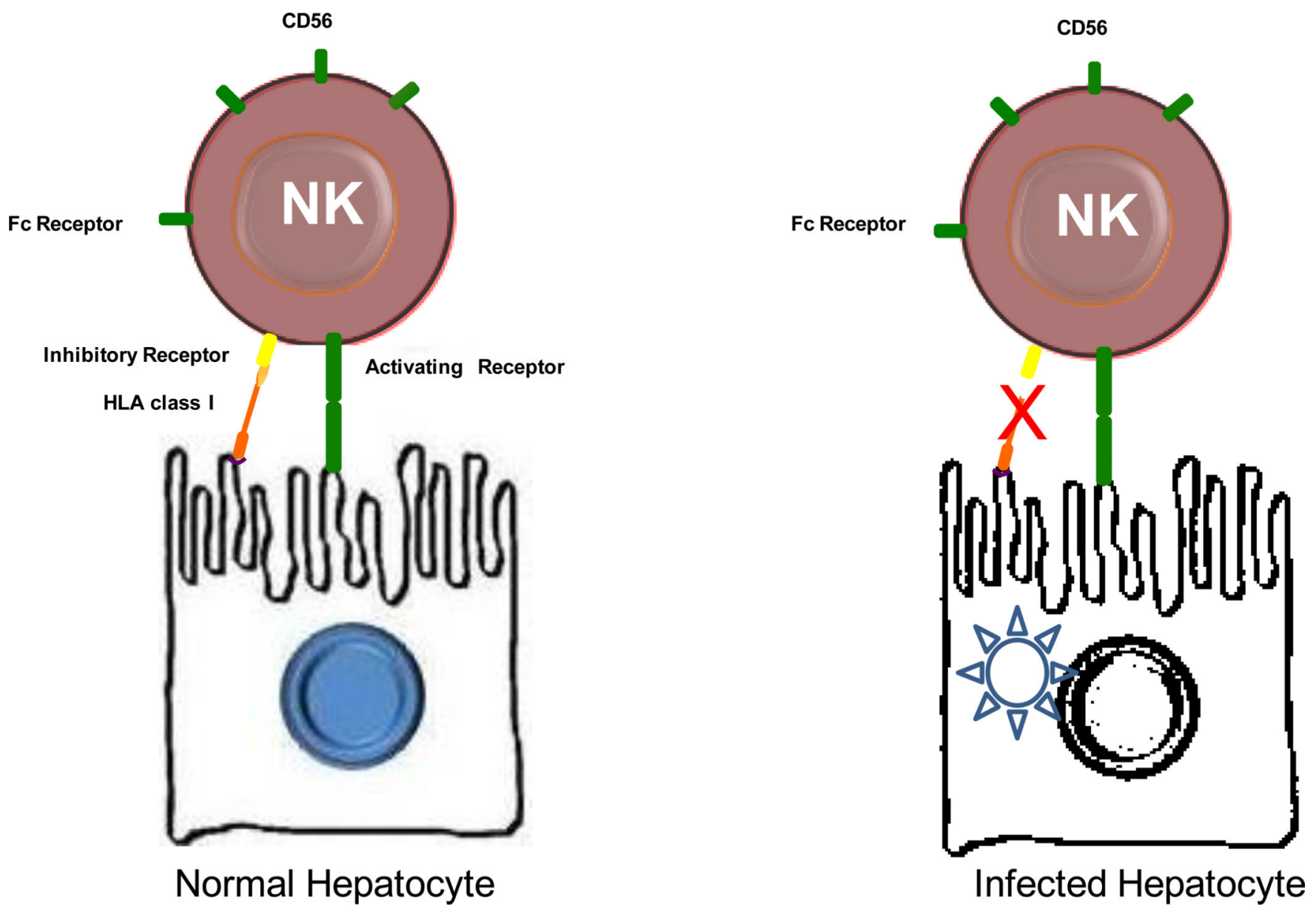

Figure 8.

Schematic illustration of NK cell receptors and killing of viral hepatitis infected cells. Under normal conditions, non-infected cells are not killed because inhibitory signals from HLA class I molecules prevail over activating signals. Virus-infected cells are characterized by altered expression of HLA class I molecules. This disrupts the inhibitory signals and allows activation of NK cells and subsequent lysis of the infected hepatocytes. NK-mediated killing of infected hepatocytes is not operated in viral hepatitides. 

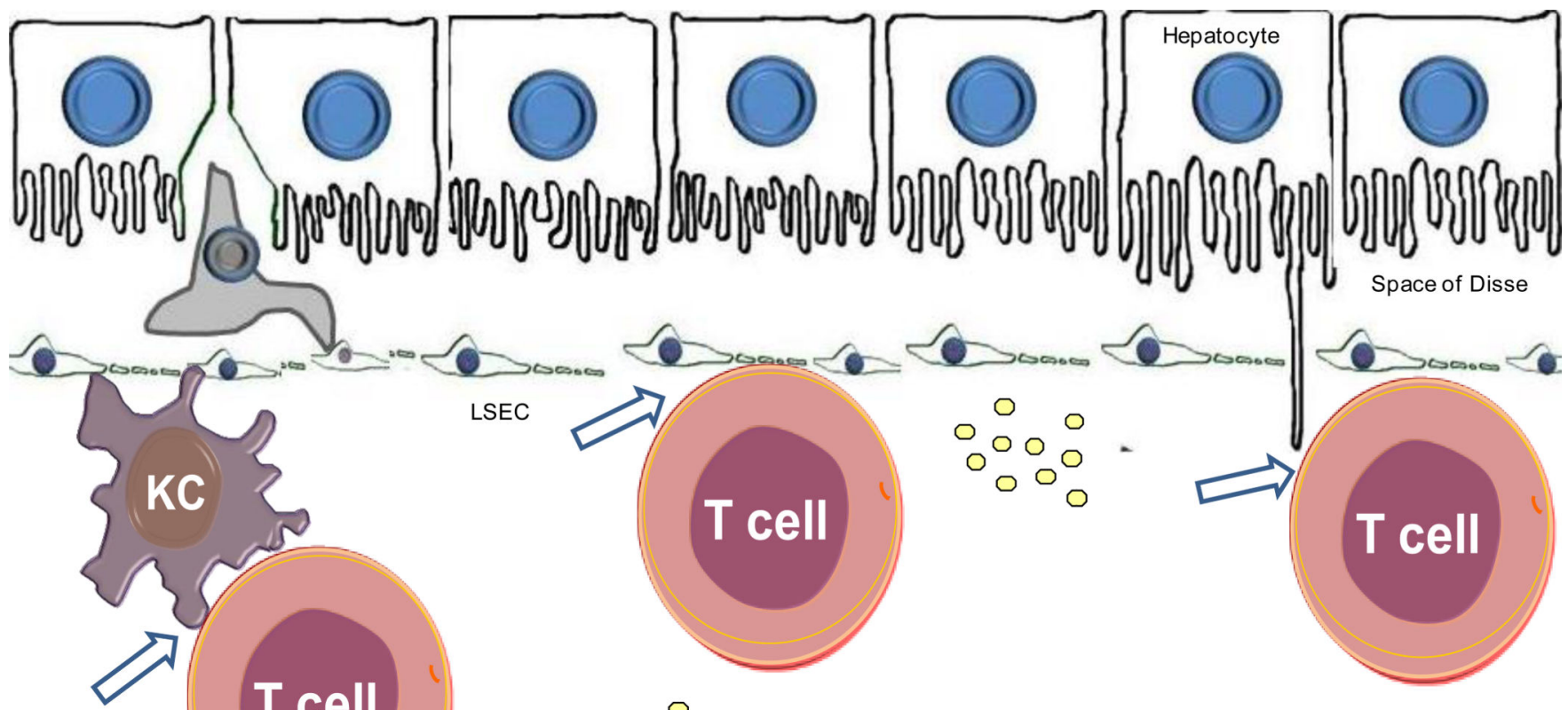

$\begin{array}{lll}0 & 0 & 0 \\ 0 & 0 & 0 \\ 0 & 0 & 0 \\ 0 & 0\end{array}$

cytokines

Figure 9.

Cell-cell interaction which can lead to activation of naïve $\mathrm{T}$ lymphocytes within the liver include contact with Kupffer cells (KC), liver sinusoidal endothelial cells (LSEC) or hepatocytes (indicated by the respective arrows). 


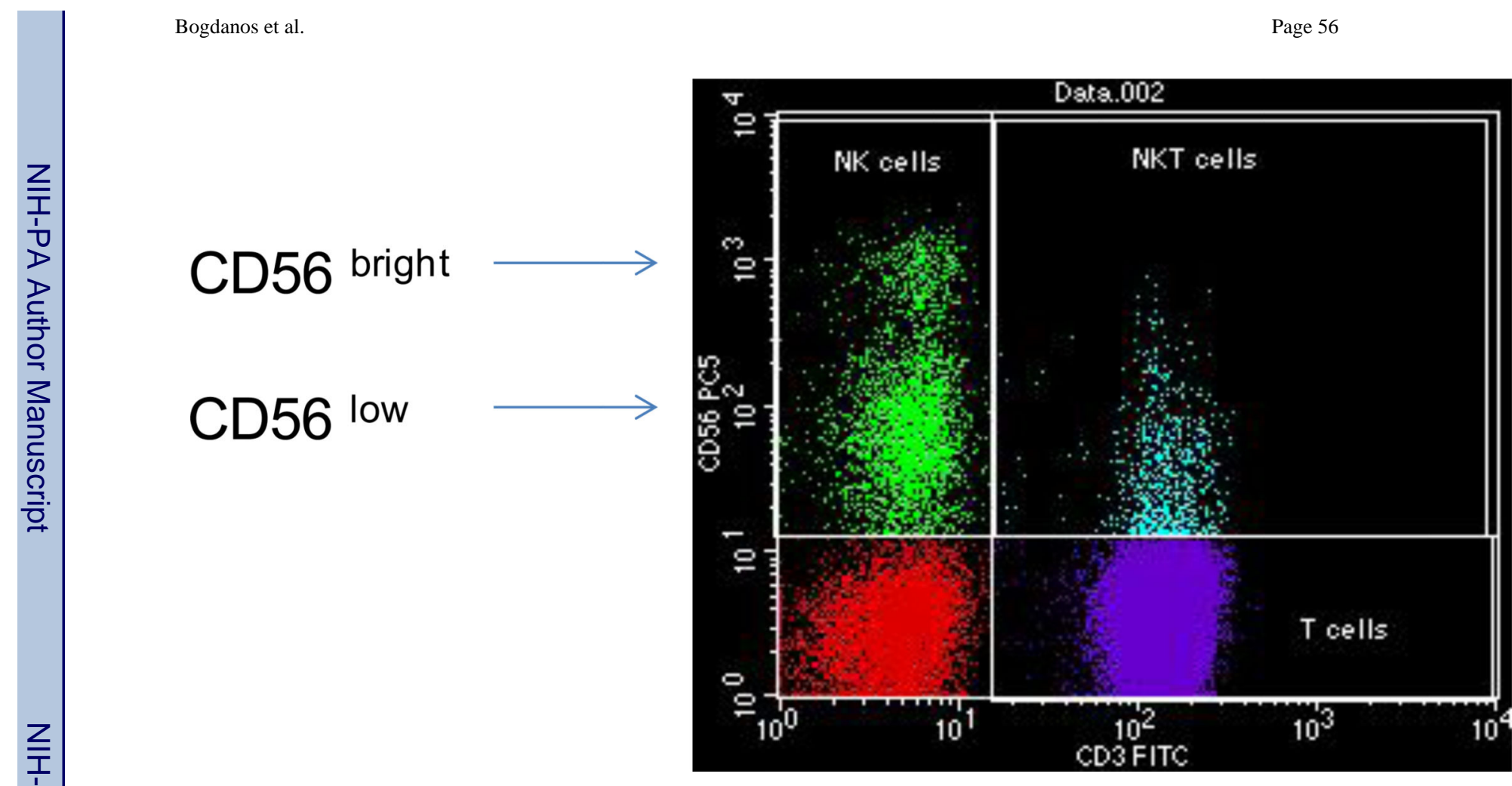

Figure 10.

Flow cytometric analysis of peripheral blood reflects the relative proportion of bright and low NK $\left(\mathrm{CD} 36^{+}\right)$cells, NKT $\left(\mathrm{CD}^{+}{ }^{+} \mathrm{CD} 56^{+}\right)$and T-cells $\left(\mathrm{CD}^{+}{ }^{+} \mathrm{CD} 56^{-}\right)$in a representative donor. Bright and low NK cells can be seen. 


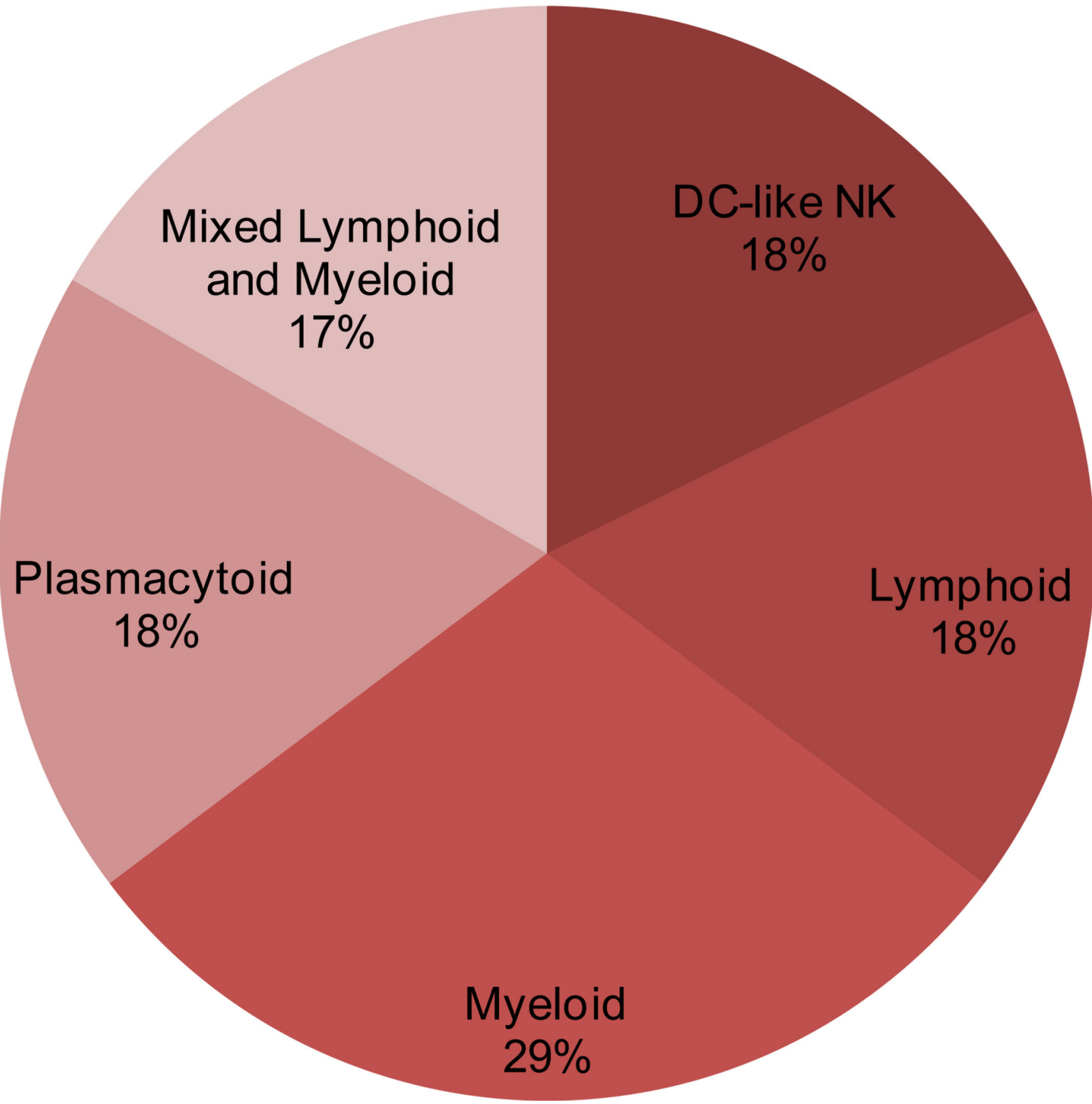

Figure 11.

Hepatic dendritic subsets in mouse 


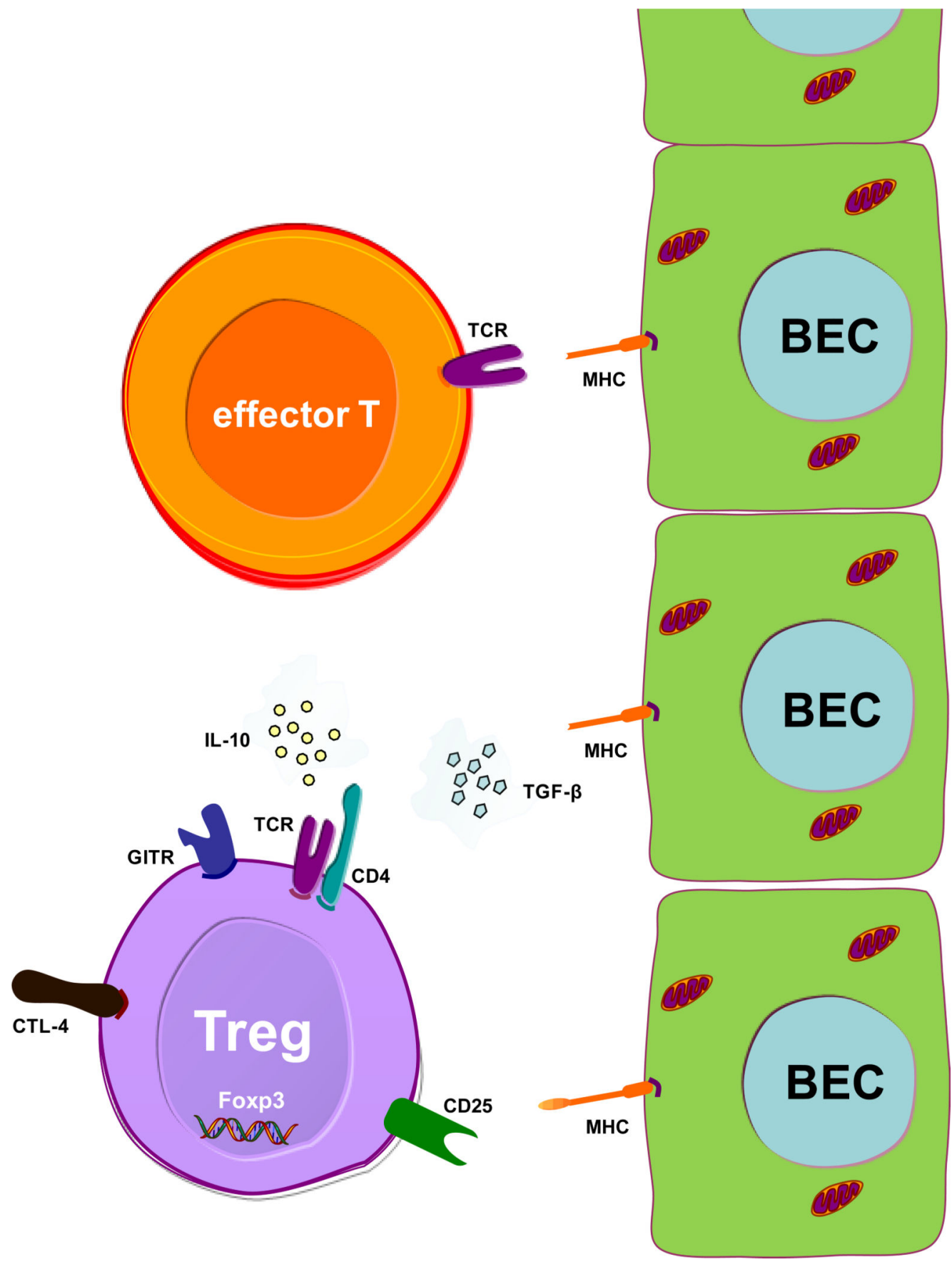

Figure 12.

Cell-Cell interaction of biliary epithelial cells (BECs) as antigen presenting cells, effector and regulatory T-cells 


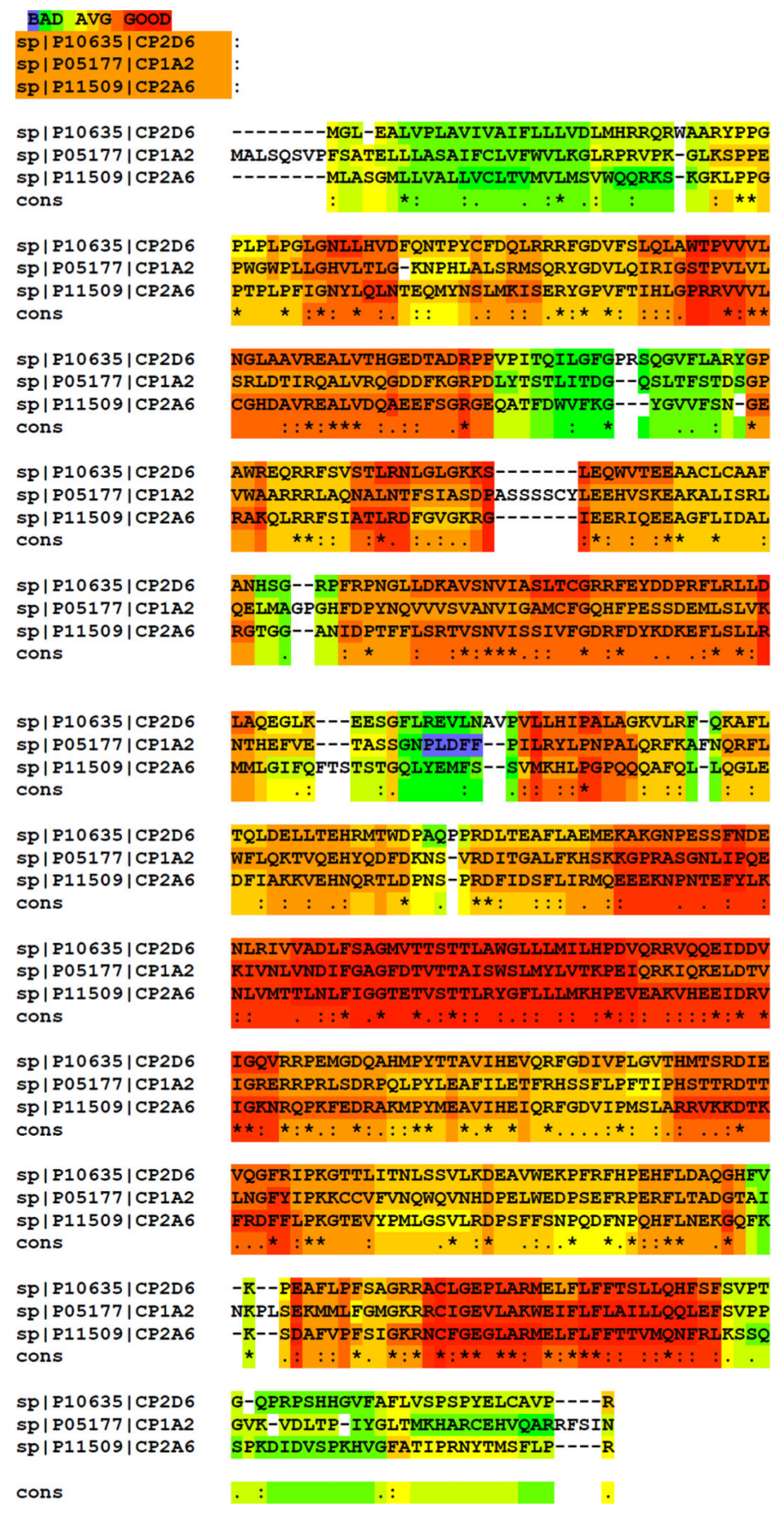

Figure 13.

CYP2D6, CYP1A2, and CYP2D6 amino acid homology.

The three cytochromes appear highly conserved but autoantibody responses against the one does not invoke cross-reactive immunity targeting the other. Amino acid analysis has been performed using the T-coffee software. Highlights of red, yellow and green correspond to areas of good, average and bad degree of homology; cons, conservation of amino acids (* indicate identical amino acids, : indicate conserved and . semi-conservative substitutions). 


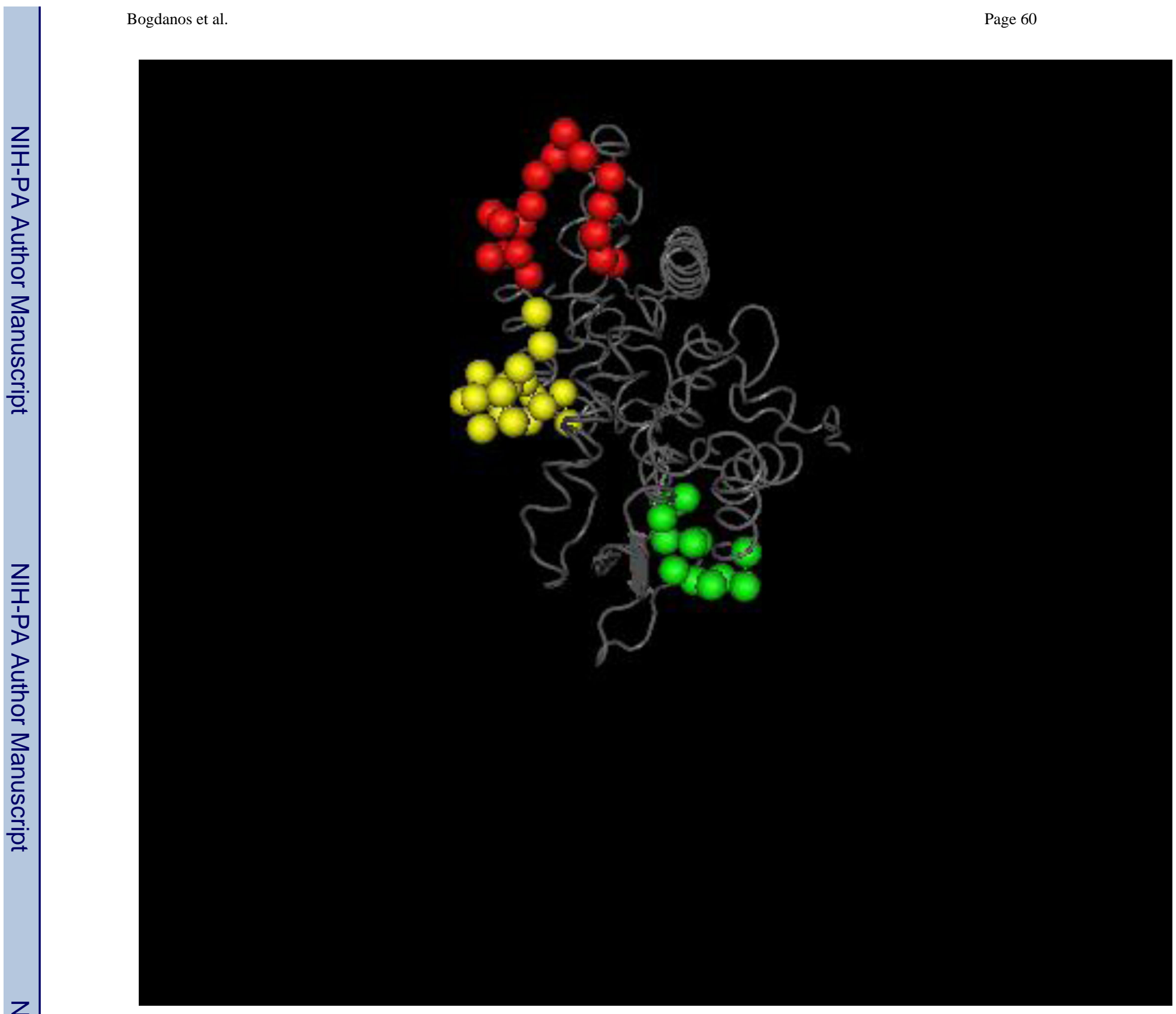

Figure 14.

3D-prediction model of the three major linear epitopic regions of human cytochrome P450IID6 (CYP2D6).

The B-cell epitopes of anti-CYP2D6 antibodies (also known as anti-liver kidney microsomal type 1 antibodies- anti-LKM1) $)^{392}$ has been studied and the three main epitopic regions recognized span CYP2D6 $254-271$, CYP2D6 ${ }_{193-212}$ and CYP2D6 $321-351$ sequences, being targeted by more than 55\% of the patients with CYP2D6 autoantibodies ${ }^{393-396}$. The antigenicity of this area may in part been explained by the exposure of these sequences to the surface of the molecule as it is illustrated in Figure 7.

Aminoacids of the autoepitopic regions are presented in the form of space fill in different colours and the remaining in a wire worm backbone (grey); in red and yellow are the 
dominant CYP2D6254-271 and CYP2D6 $193-212$ epitopes. Prediction analysis anticipates that the epitopes are exposed on the surface of the molecule. The structure was analyzed with the Cn3D visualization tool. 


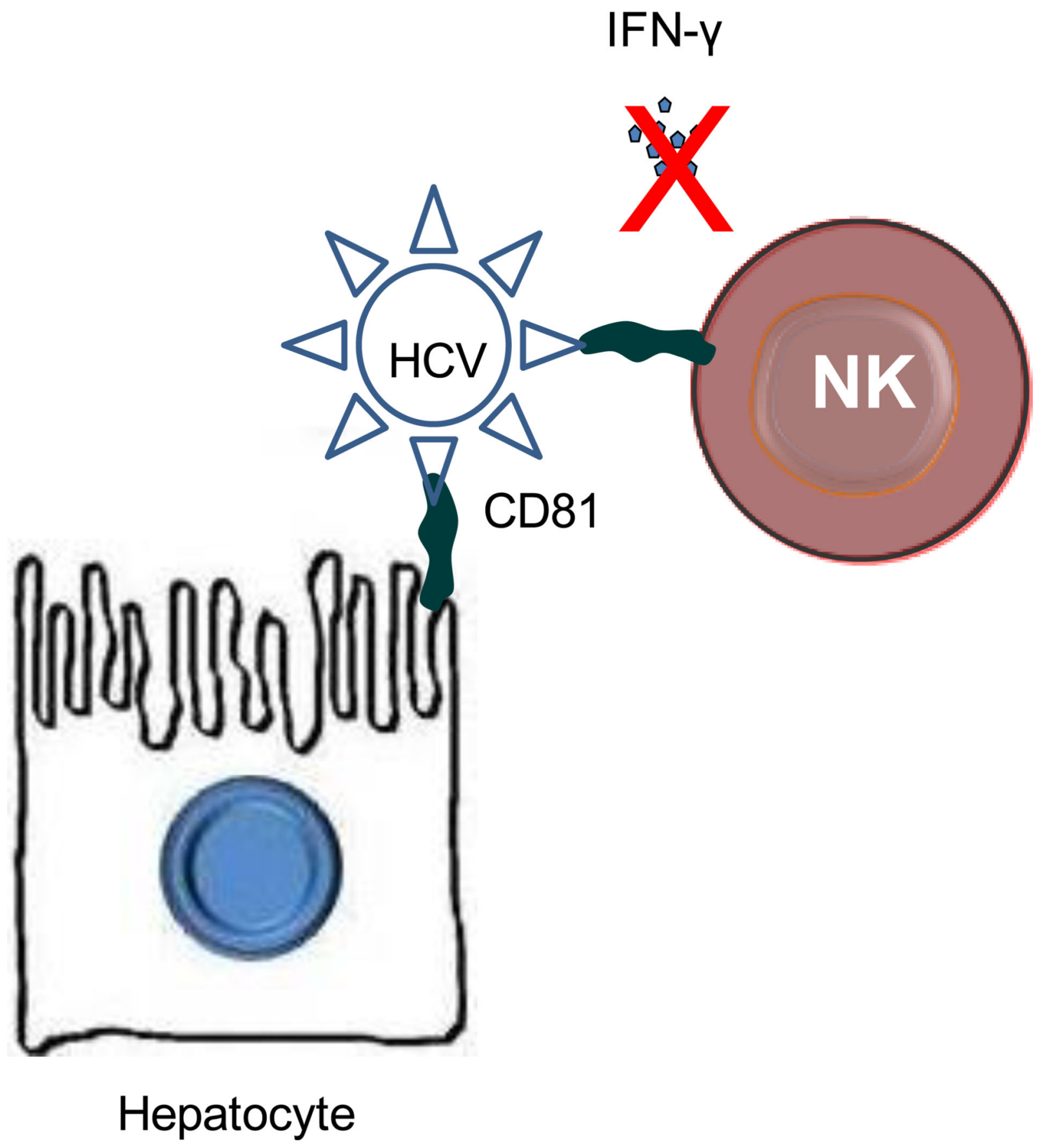

Figure 15.

The tetraspin CD81 is used by hepatitis C virus to entry the hepatocyte. Expression of CD81 by NK suppresses the induction of pro-inflammatory cytokines such as interferon- $\gamma$ and inhibits the cytotoxic capability of these cells allowing for the persistence of the virus. Other HCV co-receptors (for further details, see main text), expressed by cells of the innate immune system resident within the sinusoids, may participate in a similar fashion facilitating the inability of the host to clear the virus. 


\section{Table 1}

Percentage of total volume of cellular and extracellular compartments in liver $^{7}$.

\begin{tabular}{|l|c|c|}
\hline & Mean $\%$ & \pm SE \\
\hline Cells $\mathbf{( 8 4 . 1 \% )}$ & & \\
\hline Hepatocytes & 77.8 & 1.15 \\
\hline Liver Sinusoidal Endothelial Cells & 2.8 & 0.2 \\
\hline Kupffer Cells & 2.1 & 0.3 \\
\hline Hepatic Stellate Cells & 1.4 & 0.2 \\
\hline Extracellular Spaces $\mathbf{( 1 5 . 9 \% )}$ & & \\
\hline Sinusoidal lumen & 10.6 & 0.45 \\
\hline Disse space & 4.9 & 0.35 \\
\hline Biliary canaliculi & 0.4 & 0.05 \\
\hline Total Sum (100\%) & $\mathbf{1 0 0 \%}$ & \\
\hline
\end{tabular}

Data are presented as mean $\% \pm$ standard errors (SE) of the mean 


\section{Table 2}

Phenotypic markers of liver sinusoidal endothelial cells as reported by various studies. Liver sinusoidal endothelial cells express CD54, vWF, CD31 in more than three studies

\begin{tabular}{|l|l|}
\hline Molecule & References \\
\hline CD4 & $62,382,383$ \\
\hline CD14 & 382 \\
\hline CD16 & 382 \\
\hline CD31 & $67,384-386$ \\
\hline CD32 & 67,382 \\
\hline CD34 & $384,386,387$ \\
\hline CD54 (ICAM-1) & $62,382,383,385-388$ \\
\hline CD106 (VCAM-1) & 387 \\
\hline AcLDL & 388,389 \\
\hline vWF & $67,382,384,386,390$ \\
\hline VIII & 388,390 \\
\hline MHC-I & 388 \\
\hline MHC-II & 70,382 \\
\hline CD11b & 388 \\
\hline CD11c & 388 \\
\hline CD40 & 70 \\
\hline CD80 & 62,70 \\
\hline CD86 & 62,70 \\
\hline CD105 & 70,388 \\
\hline L-SIGN & 388 \\
\hline & \\
\hline
\end{tabular}

The relative expression of these markers varies amongst studies. Methodology used for the assessment of their expression included immunohistochemical analysis, PCR and flowcytometry using mouse, rat or human cultured LSECs (reviewed in 15); CD, cluster of differentiation; ICAM-1, intercellular adhesion molecule 1; VCAM-1, vascular cell adhesion molecule 1; AcLDL, acetylated low-density lipoprotein; vWF, von Willebrant factor; L-SIGN, liver/lymph node-specific ICAM-3-grabbing nonintegrin 